LIf

Birds 


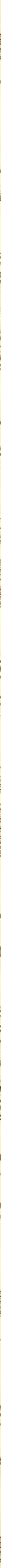




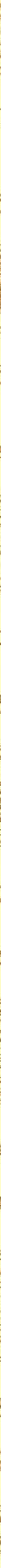





$13011+1 \mathrm{ct}$

urm thalogy 


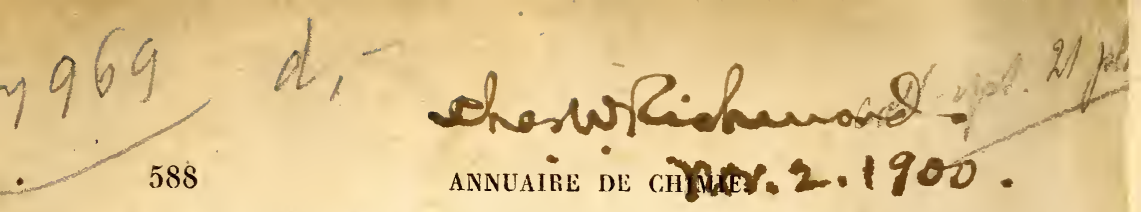

MM. Laveran et Millon citent ici plusieurs observations.

Le sel de Seignette s'appliquerait sans doute très-bien s'il était administré, suivant la méthode d'absorption, aux maladies qui se caractérisent par une sécrétion anormale d'acide urique. Ce sel communique, en effet, une activité particulière à la digestion ; le carbonate alcalin qui se forme est apte à dissoudre l'acide urique, et à prévenir ainsi la formation des dépôts ; le médicament pénètre sous forme d'aliment, et comme ce dernier semble la cause la plus directe du mal, le remède se produit aux sources mêmes de l'affection.

Après avoir étudié les transformations d'un médicament qui pouvait se brûler en partie, MM. Laveran et Millon ont observé le passage d'une substance dont tous les éléments, fortement oxydés, ne pouvaient contracter dans l'économie animale aucune oxydation nouvelle, ils ont fait choix du sulfate de soude.

Les urines contiennent normalement de l'acide sulfurique combiné, dont la proportion a été déterminée; elles varient de $2 \mathrm{gr}$. à $2,5 \mathrm{gr}$. en calculant sur l'acide sulfurique anhydre $\mathrm{SO}^{3}$. Ie sulfate de soude suit dans son passage les mêmes règles que le sel de Seignette. A doses fractionnées, les individus vigoureux et convalescents l'absorbent et le rejettent sans modification aucune. On fait arriver ainsi sans efforts 10 et 15 grammes de sulfate de soude dans les urines.

Dans des conditions contraires, lorsque le sujet est faible, lorsque la dose est forte et unique, ou bien si la fièvre agit, si les voies digestives sont dérangées, les urines ne contiennent que la proportion normale d'acide sulfurique.

Il est impossible de ne pas remarquer ici que les voies de l'absorption sont parallèles à celles de la combustion.

L'administration du soufre fournit des résultats négatifs; il ne s'absorbe pas, et n'est oxydé ni modifié en aucune façon.

L'inertie bien constatée de la salicine a fait borner son emploi à quelques cas de fièvre intermittente légère. Il était curieux de savoir si cette substance entièrement combustible, mais qui renferme une énorme proportion de carbone, et diffère ainsi très-notablement des autres substances alimentaires, ne subirait pas quelque transformation particulière. Dix individus qui ont fait usage de la salicine, ont constamment offert le même résúltat. Leurs urines contenaient toutes de l'hydrure de salicyle et de l'acide salicylique. 


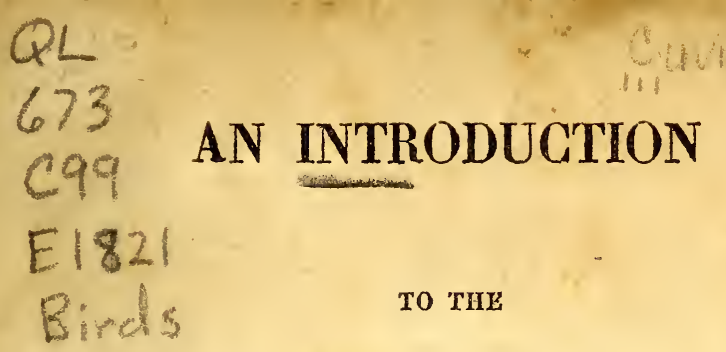

\title{
ORNITHOLOGY OF CUVIER,
}

FOR THE USE OF

\section{STUDENTS AND TRAVELLERS.}

\author{
By T. EDWARD BOWDICH, Ese.
}

CONDUG TOR OF THE MISSION TO ASHANTEE, MEMBER OF THE WETTERAVIAN SOCIETY OF NATURAL HISTORY.

PARIS,

PRINTED BY J. SMITH.

1821 . 



\section{P R E F A C E.}

\section{mereverever}

'T HIs Manual is published with the same useful view which has been submitted in the Preface to the "Analysis of the Natural Classification of Mammalia.'

The text is translated from Cuvier, arranged in a tabular form, illustrated by figures, and explained by notes comprehending the additional information which $I$ have acquired during a patient study of the subject, preparatory to second travel in Africa. 



\section{THE SECOND CLASS OF VERTEBRATED ANIMALS.}

\section{BIRDS}

Ane vertebrated oviparous animals, with double respiration and circulation, organized for flight. Their lungs, not divided, fixed against the ribs, (1) are enveloped by a membrane pierced with large holes, which allow the air to pass into several cavities in the breast, the lower stomach, arm-pits, and even the interior of the bones; so that this fluid not only bathes the surface of the pulmonary vessels, but also that of an infinity of vessels in the rest of the body. (2) Thus, Birds brealhe in certain respects by the branches of the aorta, as well as by those of their pulmonary artery; and the energy of their irritability is in proportion to the quantity of their respiration. Their whole body is so disposed as to partake of this energy. (3)

(1) The lungs of Mammalia are free and divided, and the diaphragm, which separates the cavity of their breast from that of their belly, does not exist in Birds.

(2) In Mammalia the inspired atmospheric air proceeds no further than the lungs, where it is immediately decomposed, the oxygen remaining to purify the blood which has been returned by the veins, and the nitrogen escaping, or (according to recent conclusions on this long contested point) entering into the body in very small portions : we know that nitrogen is found by chemists in all animal substances except fat (which when burned produces water and carbonic acid in the same proportions as vegetables); in plants, it is only found in the Fungi and in the perisperm of the Graminece. The atmospheric air not only performs its office in the lungs of Birds, but a portion of it proceeds to the aerian cavities (which are membranous bags, pervading even the substance of the beak and the skins of the feathers), insinuates itself between the muscles, and exercises the same salutary action on the blood contained in the vessels of these various parts of the body, as on that which has reached the lungs. The blood of Birds, from this greater proportion of oxygen, is of a much brighter red than that of Mammalia.

(3) The fact that two common Sparrows consume as much air as a Guinea $\mathrm{Pig}$, demonstrates the grreater capacity of the smaller frame of Birds, by means of the aerian cavities. Their system is consequently 
Their anterior extremities, destined to support them in flight, cannot serve either for resting on or grasping; they are consequently biped, and take objects from the ground with their mouth : the body being necessarily inclined forwards beyond their feet, the thighs are in advance, and the toes are elongated to form a sufficient basis. The pelvis or basin is much extended in length, to furnish an adequate surface for the attachment of the muscles which support the body on the thighs. There is also a suile of muscles going from the basin to the toes, and passing over the knee and heel, so that the mere weight of the bird curves or contracts the toes; it is thus that they are enabled to sleep perched upon one foot.(1) The ischions, and especially the pubes, are prolonged backwards, and are placed wider apart, to leave the space necessary for the developement of the eggs. See Pl. 1.

The neck and beak are elongated to enable them to reach the earth, but the former has sufficient mobility to bend backwards when the bird is standing still; it has, therefore, many vertebræ: on the other hand, the trunk, which merely serves as a support to the wings, is necessarily moveable only in a small degree. The sternum (to which the muscles which lower or depress the wing to strike the air in flight are attached) is of a very great extent, and its surface is further augmented by a plate or kcel, projecting

charged with more oxygen, which we know to be the powerful supporter of respiration, since a small animal, when confined in oxygen gas, lives thrice as long as another confined in the same bulk of common air. From imbibing a much greater proportion of this vivifying principle, Birds enjoy a much greater irritability; that is, their muscular force and digestive powers are greater, and all their efforts and actions are more energetic, instantaneous, and vigorous than those of larger animals whose construction does not afford these cavities. Irritability depends on respiration and circulation; sensibility on the brain and nerves. It is believed that the high temperature which the bodies of Birds attain, especially when sitting, and that extreme force which they employ in the act of flying, continued for several days, both depend on the action of the air on the blood.

(1) The course of these muscles from the ilium to the nails, is traced in the leg of a common Sparrow, fig. 14. It is evident, that when the angles $\alpha a$ are lessened (on the femur, tibia, and tarsus, $f t T$, becoming more nearly parallel to each other by the stooping of the bird on the perch), the tendons are strained to pass over the additional length creatcd by the greater intervals, $b c$, between the joints, and the toes to which these tendons are fixed are cramped by the action. There is generally a distinct tendon passing to each point of the toes, and they unite above the knee. From the ilium to this point of union it is a tsuscular apparatus, but from thence it becomes tendon. 
from the middle. It is formed of five pieces : a middle, of which this projecting plate is a part; two anterior lateral for the attachment of the ribs; and two exterior lateral for the extension of its surface. (1) The greater or lesser degree of ossification of the latter denotes more or less vigour for flight. The furcula, produced by the union of the two clavicles, and the two powerful supports or buttresses formed by the coracoid apophyses, (2) keep the shoulders widely apart; the wing sustained by the humerus, by the fore arm, and by the hand (which is elongated, shewing one finger and the vestiges of two others), (3) bears a row of elastic pens along its whole length, considerably extending the surface which strikes or gives the shock to the air. The pens adhering to the hand are called primary, and there are always ten; those which proceed from the fore arm are called secondary, their number varies ; the weaker feathers attached to the humerus are called scapulary; the bone which represents the thumb has also some pens, called bastards. (4)

(1) These five pieces are only distinct in the young bird; see the sternum of a fowl, fig. 15, from Geoffroy's Memoir in the 10th volume of the 'Annales de Musée, wherein he observes, that, in general, one half of the sternal ribs, $r r$, proceed from the anterior laterals, and the other half from the posterior laterals; but it sometimes happens, that the greater number, or even the whole, are attached to the former: $a \quad a$ are the anterior laterals, $p p$ the posterior; $s$ is the part corresponding to our sternum.

(2) See pl. 1. The apophysis is the base or round end of the bone, fitting into the opposite socket; the epiphysis is a small bone articulated on the upper surface of the extremity of a large bone, as in the humerus of pl. 1: the trace of these articulations remains distinct in Mammalia for six or seven years; but in Birds they are obliterated very soon after birth, their more active life demanding and perfecting an earlier ossification of the epiphysis. We know that the bony matter is deposited by the blood of the arteries, whilst the calcareous is carried off by the lymphatic vessels; consequently, as the circulation of Birds is much more rapid, from the stimulus of the greater proportion of oxygen, the bony matter is supplied and appropriated much more speedily than in Mammalia.

(3) In Mammalia it is always the middle finger which is rudimentary when the others are wanting; hence it is concluded to be the middle finger which is the most perfect in the arm or wing of Birds; see pl. $1, f j$.

(4) See fig. 17, the bones of the wing of a common Sparrow; also fig. 16. The primaries are also called the greater remiges, and the secondaries the lesser; the lower scapularies are called the tectrices majores, the upper the tectrices minores; the tectrices scapulares are situated at the lateral edge of the wing nearest the body 
The bony tail is very short, but it also bears a row of strong pens, which, by spreading, contribute to the support of the bird; their number is generally twelve, sometimes fourteen, and, in the Gallinacece, even as many as eighteen.

The legs have a femur, a tibia, and a peronæum or fibula, connected with the femur by an elastic ligament, by means of which the extension is maintained without any effort on the part of the muscles. (1) The tarsus and metatarsus are represented by a single bone, terminating, towards the base, in three pullies.

There are most frequently three toes in front, and a great toe behind; the latter is sometimes wanting. The great toe is directed forwards in the Martins. In the Scansores (Climbers) the last as well as the great toe is directed backwards. The number of articulations or joints increases at every toe, beginning with the great toe, which has two; and ending with the last toe, which has five. (2)

Birds are generally covered with feathers, the species of tegument best adapted to defend them from the rapid variations of

of the bird, and are particularly developed in the Alazda (Merops), hanging down between the body and the wing. The bastards form what is sometimes called the alula; they are strong feathers, or pens, sitnated in the upper end of the under surface of the wing, and very much developed in the Genus Falco. The tectrices inferiores are soft feathers between the bastards and the body. The feathers of the tail (which also has its tectrices superiores and inferiores) are called rectrices, from being compared to a helm.

(1) I have attempted to render this clear by the figures 7,8 and 9. In fig. 7, the ligament is in the relaxed state in which it rests when the femur and tibia are nearly perpendicular, or at least form a very obtuse angle; $r$ is a small rise or swelling in that part of the bone, in passing over which the ligament is compelled to strain or lengthen itself, as in fig. 8; directly it has passed this swelling, the strain ceases, and it instantly contracts, resuming the same state as at first, but on the contrary side of the swelling, as in fig. 9. Thus the peculiar jirk in the walk of Birds, particularly in the Gralloe, is explained; the exertion of the muscles raises the leg and foot from the ground, until the femur and tibia form the angle which strains the ligament to the utmost, as in fig. 8 ; and the sudden contraction of this ligament spontaneously raises the foot with a catch or jerk, as much higher from the ground as the gait of the bird requires; in setting the foot to the ground in order to raise the other, the muscles are again called upon to act, until the ligament has resumed the position of fig. 8 , its subsequent and sudden release and contraction replacing the foot on the ground as at first.

(2) This is also the case with Reptiles; in Mammalic there are always an equal number of joints to each toe. 
temperature to which their movements expose them. The aerian cavities which occupy the interior of their body, and even the place of the marrow in the bones, diminish their specific gravity. (1) The sternal portion of the ribs is ossified like the vertebral, in order to give more force to the dilatation of the breast. (2)

The eye of Birds is disposed so as to distinguish near and distant objects equally well. A vascular folded membrane, which proceeds from the bottom of the globe to the edge of the chrystalline, probably contributes to this property, by displacing the lentil. The anterior face of the globe is strengthened by a circle composed of bony pieces; and besides the two ordinary eye-lids, there is always a third placed in the inner angle, which, by means of a curious muscular apparel, can cover the front of the eye like a curtain. (3) The cornea is very convex, but the chrystalline is flat, and the vitrea small.

The ear of Birds has but one bone between the tympanum and the fenestra ovalis ; (4) their helix is a cone, scarcely arched; but their semi-circular canals are large, and lodged in a part of the skull, where they are environed on all sides by aerian cavities, which communicate with the os quadratum. The nocturnal birds alone have a large exterior conch, which, however, does not project like that of quadrupeds; it is generally covered with feathers with finer beards than the others. (5)

The organ of smell, hid in the base of the beak, has generally

(1) The purpose of this organisation, however, is not well understood ; it is not to aid their flight, as we might at first suppose, since the Ostrich and the Casoar are full of these aerian cavities, and yet scarcely fly at all; whilst the Genera Larus and Anus, (with the exception of the common Duck) and Birds which hunt on the surface of waters, whose frames are comparatively deficient in these cavities, $(\mathrm{fig} \cdot 15, \mathrm{r} r)$ and whose bones are full of marrow instead of air, fly exceedingly well.

(2) It will be recollected that this part of the ribs is only cartilaginous in Mammalia.

(3) This, which is called the nictitating membrane, being translucent, defends the eye of the hird when flying in face of the sun, without obstructing the sight. It is for the same purpose, in fact, as the coloured glass in our instruments for observing the sun. It also protects the eye of the Diving Birds, when under water. larly.

(4) In Mammalia there are three, and they are articulated angu-

(5) We must lay back the feathers with our fingers to discover the conch, which is a thin leathery piece of flesh, in shape not unlike our own; but the orifice of the ear is behind instead of before it. 
only cartilaginous cornea, three in number, which vary in complication; it is very sensible, although it has not any sinus hollowed out in the thickness of the skull. (1) The width of the bony openings of the nostrils determines the form of the beak; and the cartilages, the membranes, the feathers, and other teguments which narrow these openings, influence the strength of smell, and the kind of nourishment.

The tongue has but little muscular substance, and is sustained by a prolongation of the os hyoidis. (2)

The feathers as well as the pens, for they only differ in size, are composed of a stem (hollow at its base), and beards, which bear others still smaller; their texture, their brilliance, their strength, their general form, varies to infinity. The touch must be weak in all the parts which are covered with feathers; and as the beak is almost always horny, and not very sensible, and the toes are covered with scales above and a callous skin below, this sense must be of very little efficacy in birds.

The feathers fall twice every year. In certain species, the winter plumage differs from that of the summer; in the greater number, the female differs from the male by less lively colours, and then the young ones of both sexes resemble the female. When male and female adults are of the same colour, the young ones have a plumage peculiar to themselves.

(1) In Mammalia, these sinuses (which are distinguished from simple cavities by having a channel of communication with the seat of some organ) are covered, as well as the cornea, with a soft membrane, upon which the branches of the olfactory nerves are distributed: their surface (against which the volatile particles of the effluvia of bodies strike after passing through the nose) is thus much more developed or spread, and consequently more susceptible. The tracing of the olfactory nerves to the palate, by Jacobson, satisfactorily accounts for the intimate sympathy between taste and smell. The projection of forehead in the Owl and the Elephant, which induced the ancients to attribute superior wisdom to them, is caused by the large cells between the interior and exterior sufaces of the frontal bone. In the Elephant they communicate with the nostrils, and are therefore true sinuses, which probably strengthen the sense of smelling; but in the $\mathbf{O w l}$ they are simple insulated cavities.

(2) See fig. 12, wherein $c$ is the cartilaginous prolongation of the os kyoidis, and $t$ the upper part of the trachea, the orifice of which is closed at the pleasure of the animal. Dumeril observes, that the organ of taste scarcely exists in Birds; that, in general, they have no saliva, and swallow their food without mastication. There are some, however, Parrots and Ducks, for instance, which appear to taste their food, and also possess the organs for furnishing saliva. 
The brain of Birds has the same general characters as that of other oviparous vertebrated animals, but it is distinguished by a very considerable proportionate size, which often even surpasses that of the same organ in Mammalia. Its volume consists principally of tubercles, analogous to the "cannelés," and not in the hemispheres, which are very thin, and without circumvolutions. (1) The cerebellum is tolerably large, almost without lateral lobes, and almost entirely formed by the vermiform process.

The trachea of Birds has its rings entire; at its bifurcation is a glottis, generally provided with distinct muscles, and called the inferior larynx; it is there that the voice of birds is formed; the enormous volume of air contained in the aerian cavities contributes to the strength, and the trachea, by its various forms and movements, to the modifications of the voice. (2) The superior larynx is very simple, and does not avail much.

The face or superior beak of Birds, formed principally by their intermaxillaries, is prolonged behind in two arcades; the internal

(1) This is the corpus rectiforme, which makes a part of the cerebellum in Birds; there is no middle lobe, which disappears in all the Mammalia below Apes. Sensibility is considered to depend on the proportion of brain and nerve: in our common Ducks and Fowls, the brain is not more than 1-300th part of the size of the whole body, whilst in Swallows, Parrots, Canaries, and others, it amounts to 1-14th part. Thus, the former, in whom a much smaller proportion of nerve is developed, are unequal to the art of making nests; whilst the latter display much ingenuity in the fabric, know where to find them again after a long absence, whistle and sing in their dreams, and display their superior sensibility in a variety of ways. We know that Swallows frequently fall to the ground in fits from their extreme sensibility.

(2) See fig. 13, wherein $g$ is the glottis, which is of a horny substance. In Mammalia the bifurcation takes place without the intervention of a glottis. The inferior larynx is enlarged variously (sometimes into two large lobes) according to the nature of the voice of the bird. The circles which are continued all round in Birds, extend only half round the trachex of Mammalia. In the latter the voice is formed in the upper part of the trachea; in the former, in the lower or distinct part of which we have been speaking, and which has a small apparatus within, precisely similar to the mouth of a clarionet; whilst in Mammalix the trachea contains two chords only, which vibrate whenever we choose to pass a current of air through them, and thus produce the voice. This may be demonstrated in a degree by blowing gently through the trachex of Mammalia and Birds, even after dissection. Referring to this, M. Cuvier, in his Comparative Anatomy, has happily compared the trachea of Birds to a wind, and that of II a mmalix to a stringed instrument. 
of which is composed of the bones of the palate, and the external of the maxillaries and the jugals, both of which rest upon a flexible tympanic bone, vulgarly called the square bone; (1) this same face or front is articulated or united to the skull above by elastic plates; a mode of union which always leaves some mobility. (2)

The horn which covers the two mandibles supplies the place of teeth, and is sometimes prickled in such a manner as to represent them; its form, as well as that of the mandibles which support it, varies to infinity, according to the kind of food to which each species is accustomed.

The digestion of Birds is in proportion to the activity of their life and the strength of their respiration. The stomach is composed of three parts: the crop, which is an enlargement of the osophagus; the succenturium, a membranous stomach, furnished within its cells by a multitude of glands, the juice of which is imbibed by the aliments; and the gizzard, armed with two vigorous muscles, united by two tendons, radiated and covered withinside by a velvet-like cartilage. (3) The aliments are ground there, and the more easily in proportion as the Birds take the precaution to

(1) In Mammalia the os quadratum (see fig. 1, pl. 2) makes but one with the temporal; Geoffroy first shewed that it was distinct in the $2 \mathrm{~d}, 3 \mathrm{~d}$, and 4th Classes of Vertebrated animals. In the Genus, Testudo of the 3d, it appears scarcely separated, as if in the act of quitting the temporal.

(2) See the skull of a Duck, figs. 1 and 2: the maxillary ceases at the small rising which indicates its articulation with the jugal. The upper mandible being united to the skull by an elastic plate ( $p$. fig. 3.) like a very thin slip of whalebone, has the power of raising itself towards the forehead; a motion impossible to the upper jaws of Mammalia.

(3) Fig. 11 was drawn from a preparation of the inside of a common fowl; $\alpha$ is the osophagus; $s$ the succenturium, and $g$ the gizzard, which communicates internally at $c$; $d$ is the duodenum or the first 12 inches of the intestines. The crop, or prolobus $(p$.$) , is represented$ empty; when full, it swells out like that of the Vulture, fig. 29. Fig. 6 is the stomach of the Heron; fig. 5 of the Procellaria Pelagica; fig. 4 of the Ostrich : the crop is wanting in each, but the succenturium is considerably developed. In the Heron it is confounded with the gizzard, which, however, is easily distinguished by its muscular fibres. In the Procellaria, the succenturium is very distinct from the gizzard or third stomach. In the Ostrich, the stomach seems divided into two parts; the upper and smaller of the two is more glandulous than the other. The grain or aliment remains long enough in the crop to be mollified by the heat and the humour (analogous to the saliva) which is discharged from its cells; so that, in fact, their food is chewed there, 
swallow small stones, to augment the trituration. (2) In the greater number of species which only live on flesh or fish, the muscles and the lining of the gizzard are reduced to an extreme weakness, and it seems to form but a single bag with the succenturium. (3) The dilatation of the crop is also sometimes wanting. (4)

The liver pours the bile into the intestines by two conduits, which alternate with the two or three by which the pancreatic liquor passes. (5) The pancreas of Birds is considerable, but their spleen is small; they want the epiploôn, the uses of which are partly supplied by the cells of the aerian cavities; (6) two blind appendices are placed towards the origin of the rectum, and at a little distance from the anus; they are more or less long, according to the diet of the bird. (7) The Herons have but one, which is short; other genera, as the Pici, want them entirely.

instead of in the mouth, which is not furnished with salivary glands like ours.

(2) The digestion of Birds is thus assisted by a mechanical in addition to the chemical power.

(3) The most striking proof that it is much more laborious to digest vegetables than flesh, is, that the intestines of the cat, which eats nothing but flesh in its wild state, become one-third longer in the domestic state, when they so frequently eat vegetables and bread: they are known to be the same species.

(4) The Anas and the Insectivores of Temminck (the Ant Eaters, the Motacilla of Lin. Cincli, etc.) also want the crop or prolobus. When the crop, or even the succenturium, is wanting, as in the Aquilæ, the Bird is supplied either with very long intestines or very long cæcums, and the upper part of the gizzard or stomach is generally armed with numerous extra glands, the juices from which compensate in a degree for the absence of the other aids of digestion. This muscular stomach or gizzard of Birds is said to be more fleshy in proportion as the animal possesses a weaker beak, or as its nourishment is more solid. On quitting this stomach, the aliments, reduced to a sort of pap or chyme, pass through the rest of the intestinal canal, wherein the most nutritive parts are absorbed for the support or repair of the body; the rest being ejected by the cloaca. Vauquelin discovered twice the quantity of phosphate of lime in the excrements of Birds, which he found in the grains forming their exclusive nourishment.

(5) The secretion of the pancreas is to moderate or soften the strength of the bile.

(6) The epiploön is a sort of web, enveloping the intestines of Mammalia, to support them in their place, and the injury of which is the cause of hernia or rupture.

(7) The use of the cacum is not known; see fig. 10, c c, those of the common fowl; this Bird is provided with long cæcums as well as the 
The cloaca is a pocket, in which the rectum, the ureters, and the spermatic canals, or, in the female, the oviductuses, (1) terminate; its exterior opening is the anus. (2) In general, Birds do not discharge their urine, but it mixes with the solid excrements. The Ostriches, alone, have the cloaca sufficiently dilated for the urine to accumulate there.

In the greater number of genera, copulation takes place by the juxta-position of the anus; the Ostriches and several Palmipedes, however, have a penis, with a deep furrow on the outer surface, by which the seed is conducted. The testicles are situated in the interior, above the kidnies, and near the lungs; there is but one ovary and one oviductus.

The egg detached from the ovary, where the yolk only is perceptible, imbibes the exterior liquor, called the white, in the upper part of the oviductus, and is furnished with its shell in the lower part of the canal ; the young one is developed by incubation, unless the heat of the climate is sufficient, as it is with Ostriches. It has a horny tip at the end of its beak, which enables it to cleave the egg, and which falls off a few days after birth. (3)

three stomachs, since it feeds almost entirely on grain, which is one of the most difficult aliments to digest.

(1) In the winter season the oviductuses of Birds are scarcely distinguishable, on dissection; but in the spring they are very evidently developed, and the end nearest the ovary enlarges considerably, and environs it, to receive the falling eggs.

(2) In Mammalia, the rectum is continued to the anus, the ureters pass from the kidnies into the bladder, and both these channels and apertures are distinct; in Birds the anus is the inferior opening of a large bag, called cloaca, from its being a reservoir for the fæces as well as the secretions, and into which the rectum, the ureters, the spermatic ducts, and the bursa fabricii discharge their contents. The use of the secretion discharged into the cloaca by the bursa fabricii, which does not exist in Mammalia, is considered by some Naturalists to be that of colouring the yolk of the egg.

(3) Eggs require a heat of nearly $54^{0}$ of Farenheit to enable the germ to develope itself. Almost all Birds sit and fast during the incubation: they feel a sort of fever produced by maternal love, which sometimes elevates their temperature as high as $79^{\circ}$. We first observe the germ besprinkled with red spots (which we soon recognise to be blood vessels) towards the centre, where we next perceive the heart in motion; we afterwards begin to distinguish the head, with two large eyes; the beak, the wings, and the claws are then developed; but all these parts are in a state of considerable softness. The albuminous matter is absorbed in proportion to the developement of the foetus. The yolk does not appear to diminish in size, and it is only at the mo- 
Every one knows the varied industry which Birds exercise in the construction of their nests, and the tender care which they take of their eggs and their young ones; it is the principal part of their instinct. Their rapid passage through the different regions of the atmosphere, and the lively and constant action of this element upon them, afford the means of presaging variations of the atmosphere of which we have no idea; which circumstance has, from the earliest times, induced superstition to attribute to Birds the power of announcing the future; (1) neither do they want memory, or even imagination, for they dream; and every one knows with what facility they are tamed, allow themselves to be trained to different services, and retain airs and words.

\section{Division of the Class of Birds into Orders.}

Of all the Classes of Animals that of Birds is the most marked, that in which species most resemble each other, and which is separated from all others by the greatest interval; its subdivision is consequently more difficult.

Their distribution is founded, like that of Mammalia, on the organs of manducation, or the beak; and on those of prehension, that is to say, the beak, and, especially, the feet.

We are first struck with the palmated feet, or those of which the toes are united by membranes, which distinguish all the swimming birds. The backward posilion of these feet, the length of the sternum, the neck often longer than the legs (to reach the deeper places), the close smooth plumage (impervious to water). contribute to make the Palmipedes good navigators.

In the other Birds which have, generally, some little web, at least between the external toes, we observe elevated tarsi; thighs naked of feathers towards the lower part; a slender shape; in a word, all the construction proper for fording or walking along the edges of waters, to search for food. Such in fact is the diet of the greater number, and, although some live on dry land, they are called Shore Birds or Grallx.

ment when the bird is ready to be hatched, that this humour disappears, entering by the naval into the belly of the young bird. The yolk is supposed to be absorbed in the interior of the body, as it passes into the intestines, and may be considered as a sort of milk or first nourishment.

(1) The Palmipedes and Grallx, for instance, always come to land when they foresee a storm; the Procellariæ, more especially, amongst the former, and the Fulicæ amongst the latter. 


\section{( 12 )}

Amongst the true Land Birds, the Gallinacex have, like our domestic cock, a heavy appearance ; short flight; a middle-sized beak, the upper mandible vaulted; the nostrils, partly covered with a soft swelled scale; and, almost always, the toes dentated at the edges, and short membranes between those in front. They live principally on grains.

Birds of Prey have the beak crook'd, with a sharp point, and curved towards the base, which is entirely covered by a membrane wherein the nostrils are pierced; their feet are armed with strong nails. They live on flesh, and pursue other Birds : most of them, therefore, have a powerful flight. The greater number have a small web between the external toes.

The Passeres comprehend many more species than all the other Families, but their organisation offers so much analogy that we cannot separate them, though they differ very much in size and strength. Their two exiernal toes are united at their bases, and sometimes in a part of their length.

Lastly, we have given the name of Climbers to the Birds whose external toe is turned behind like the great toe, because the greater number employ a construction so favourable to the vertical position, in climbing the trunks of trees.

Each of these orders is subdivided into Families and Genera, principally according to the formalion of the beak.

\section{SECOND CLASS OF VERTEBRATED ANIMALS.}

\section{ORDERS.}

\section{Accipirres, $L i n$.}

Beak crook'd.Fig. 18.

Nostrils inserted in a cera. Fig. 18.

Talons crook'd; 3 toes before, 1 behind. A short membrane, generally, betw een the two external toes. Fig. 19.

2. Passeries.

All such as cannot be classed in the other five orders. 
3. Scansores, Illiger. Grimpeuls, Cuvier.

The external toe turned behind with the great toe. Fig. 20.

4. GaLLinace $\pi, L i$ Lin.

The upper jaw or The anterior toes mandible vaulted. Fig. united at their base 22. The nostrils placed by a short membrane, in a large membranous dentated along the space from the base of edge. Fig. 23. the beak, and covered by a cartilaginous scale. Fig. 21.

5. Gratle, Lin. EchassIEns, Cuv.

\section{4.}

Naked thighs. Fig.

6. Palmipedes.

The only birds whose neck exceeds the length of their legs.

Palmated feet, for Plumage imbued running,on shortcom- with an oily juice; pressed tarsi, fixed in skin furnished with a the hinder part of the thick down. body. Fig. 25.

Birds of Prey (Accipitres, Lin.) are distinguished or recognised by their crook'd beak and nails; powerful weapons, with which they pursue other Birds, and even the weaker Quadrupeds and Reptiles. They are the same, amongst Birds, as the Carnivora amongst Quadrupeds. The muscles of their legs and thighs indicate the force of their talons; their tarsi are rarely elongated. They all have four toes and the nails of the great and middle toes are the strongest. 


\section{(14)}

\section{LINNEUS'S}

\section{DIVISION OF THE ORDER}

\section{ACCIPITRES}

INTO

\section{GENERA:}

1. Vultur:

2. Falco.

3. Stnix.

4. Lanius.
Rostrum rectum apice aduncum. Caput impenne antice nuda cute.

Lingua bifida.

Collum retractile.

Rostrum aduncum basi cera instructum. (1)

Caput pennis arcte tectum.

Lingua bifida.

Rostrum aduncum (absque cera). (2)

Nares oblongæ, pennis setaceis recumbentibus obtectæ.

Caput grande auribus oculisque magnis. Lingua bifida.!

Rostrum rectiusculum dente utrinque versus apicem basi nudum.

Lingua lacera.

Latham divides the Order Accipitres simply into Genera, as Linnæus has done, but he has removed the Genus Lanius to the succeeding Order, like Guvier; whilst Bechstein, Temminck, and others, retain it in the present.

(1) Latham also retains this as a distinct character of the Genus Falco, whereas it is evidently common to the Genus Vultur also.

(2) The cera exists in this Genus, covered wholly, or in part, with stiff hairs. Latham subdivides this Genus into auriculatoe and inauriculatoe; the other Genera present no subdivisions, and thus the traveller, for it may be no inconvenience to the Ornithologist, is perhaps obliged to search through 41 closely printed 4 to. pages to find a species of Falco. The admirable sagacity and laborious observation of Linnæus, although he founded his system on the exterior of animals, led him to foresee many of the peculiarities of their interior construction, which the science of Cuvier has demonstrated as the bases of a natural system, and most of the Genera of the former will be recognised in the Families of the latter. 


\section{ORDER I. ACCIPITRES.}

\section{FAMILIES.}

\section{Diurna.}

Nostrils inserted in a 3 toes before; 1 be- Eyes directea sidenaked cera. Fig. 18. hind without feathers. ways.

\section{Nocturnte.}

Nostrils pierced at External toe turned Large eyes directed the anterior edge of a behind at fleasure. frontways. cera, covered more or less with stiff hairs. p.27.

The Diurnce have their eyes directed sideways; a membrane called cera covering the base of the beak, in which the nostrils are pierced; three toes before, one behind without feathers; the two external toes almost always united at their base by a short membrane; their plumage close; their pens strong; their flight powerful; their stomach almost entirely membranous; their intestines little extended; their cxcum very short; their sternum large and completely ossified, to afford a more extended surface for the attachment of the muscles of the wing; and their furcula semi-circular, and very much widened, the better to resist the violent depressions of the humeri, necessary to a rapid flight. Linnæus made but two Genera of them, which are two natural divisions, the Vultures and the Falcons. (1)

The Nocturnò have a large head, very large eyes, directed forwards, encircled by a ring of fine feathers, the anterior of

(1) I extract the following addenda from M. Temminck's description of this order, in his Manuel d'Ornithologie, after Bechstein, Meyer, and his own superb collection, universally allowed to be the first in Europe.

"Beak compressed; nostrils open; toes rough underneath; nails pointed. These birds live in monogamy; they nest on inaccessible rocks, or very high trees; the number of their eggs never exceeds six. Their food consists entirely of living, or very rarely of dead prey, which they swallow in pieces enveloped in the hairs or feathers, these substances, as well as the bones, forming a ball in the stomach, and being rejected by the mouth; they eat copiously when an opportunity presents itself, but they can fast several days; the blood of their viciims is sufficient to quench their thirst. The female is generally a third larger in size than the male." Dumeril observes that the male birds of this Order never sit on the eggs, but nourish the female while she does so. 
which cover the membrane of the beak, and the posterior the opening of the ear. Their enormous pupil admits so many rays, that they are dazzled by the full day. Their skull thick, but of a slight substance, has large cavities which communicate with the ear, and probably strengthen their sense of hearing; but their flying apparatus does not possess great force. Their furcula can resist but little. Their feathers, with soft beards and fine down, do not make the least noise when flying. Their external toe may be directed, at pleasure, before or behind. These Birds generally fly during the twilight and moonlight. When they are attacked by day, or struck by some new object, they do not fly away, but erect themselves, assume strange postures, and make ridiculous gestures. Their gizzard is tolerably muscular, although their prey is entirely animal, consisting of mice, small birds, and insects, but it is preceded by a large crop; their cæcums are long and enlarged at the end. Small birds have a natural antipathy to them, and assemble from all parts to attack them, for which reason they are employed to attract birds into snares.

\section{FAMILY I. DIURNE。}

\section{GENERA.}

1. Vultur, Lin: VulTURE.

Beak elongated, curved towards the end.

Eyes even with the head. p. 18.

Part of the head or

\section{neck bare.}

2. Griffon. Gypatros

Storr. Phène, $S a-$ vigny.

Nostrils covered with stiff hairs, directed for- tirely covered with wards, and a brush of feathers.

the same under the beak. Fig. 31.

\section{3. $F_{A \mathrm{LCO}}, \operatorname{Lin}$. FALCON. \\ Projecting eyebrows, making the eyes appear sunk, and giving them a physiognomy entirely different to that of the other Genera. Fig. 32. p. 19.}


$V$ ultures have their eyes even with their heads; their tarsi reticulated, that is to say, covered with litile roundish scales (fig. 19) ; the beak long, curved only at the end; a greater or lesser part of the head, or even of the neck, naked of feathers. The strength of their talons is not proportionate to their size, and they make more use of their beak. Their wings are so long, that they hold them half extended when walking. They are cowardly birds, and feed on carrion oftener than on living prey; after they have eaten, their crop forms a large projection above their furcula (fig. 29); a foetid humour runs from their nostrils, and they are almost reduced to a state of stupidity. (1)

The Griffons, placed by Gmelin in the Genus Falco, approach near to the Vultures by their manners and conformation. Their eyes are even with their head; their talons are proportionably weak; the wings are half spread during the time of repose; their crop, when full, projects from the base of the neck, but their head is entirely covered with feathers; their distinguishing character consists in a very strong beak, straight, crook'd at the end, swelled at the crook; and in nostrils covered with stiff bristles directed forwards, and a brush of similar bristles under the beak; their tarsi are very short, and feathered as far as the toes; their wings very long, and the third pen feather the longest. (2)

The only species of Griffon yet known is the $V$. Barbarus (Bearded Vulture, Vulturine Eagle, Lath.) the largest of all Birds of Prey in the Old World. Fig. 31 .

Falcons form by far the most numerous Division of the Diurnal

(1) The inferior mandible straight, rounded, and inclined towards the point; mouth terminating in advance of the eyes; head naked, or covered with a very short down; wings sensibly rounded; the first remex short, not equalling the sixth; their second and third less long than the fourth, which is the longest. Their flight, although slow, allows them to rise to a prodigious height; their ascent is managed by winding, and their descent in the same way; their sight is piercing; the organ of smelling singularly perfect; their attitude embarrassed, and their gait heavy: they live in troops, and feed solely on carrion; They nest on the most inaccessible rocks, carry the nourishment for their young in their crops, and vomit it before them.-Tem.

Their nests are composed of branches and small slips of wood.Dumeril.

(2) Head small; nostrils oval; feet short; four toes, the three front united by a short membrane, the middle toe very long. Nails slightly crook'd; the first remex of the wing a little shorter than the second. They live in pairs, constantly feed on living prey, which they eat on the spot without taking any away in thcir talons. - Tem. 
Birds of Prey. They have the head and neck covered with feathers ; their eyebrows form á projection which makes the eye appear sunk in, and gives a character to their physiognomy very different to that of the Vultures. The greater part feed on living prey, but they differ much amongst themselves with respect to the courage they evince in pursuing it. Their first plumage is often differently coloured to that of the adults; they only assume the latter in their third or fourth year, which has caused the species to be much multiplied by naturalists. The female is generally a third larger than the male, for which reason the latter is called Tiercelet. ( 1 )

\section{GENUS I. VUITUR.}

SUB-GENERA.

1. Vultures Proper, Cuv.

Beak large and strong. Nostrils crossways. Fig. 26.

Head and neck without feathers.

2. Sarcoramphưs, $D u-$ meril.

The cera at the base Nostrils oval and of the beak surmounted longitudinal.

by caruncula. Fig. 28, 30 .

3. Perchopterus, Cuv. GypaËros, Bechstein. Neophron, Savigny. Cathantes, Illiger.

Beak long and thin. Nostrils oval, longi- Head, only, naked. Fig. 27. tudinal.

Vultures, properly so called, have the beak large and strong, the nostrils crossways on the base, the head and neck without feathers, and a collar of long feathers at the base of the neck.They have as yet been only seen in the Old World. Vultur Fulvus, fig. 18; Vultur Cinereus, fig. 29; Vultur Auricularis, fig. 26 .

(1) Beak crook'd; the inferior mandible obliquely rounded, and, sometimes, both sloped. Nostrils lateral, rounded, open. Tarsi covered with feathers, or smooth and covered with scales. Nails sharp, very much crook'd. Wings with strong stems. - Tem. 
Sarcoramphus.-America produces some Vultures remarkable for the caruncula surmounting the membrane at the base of their beak, which is large as in the preceding, but the nostrils are oval or longitudinal. These are the Sarcoramphi of Dumeril. Vultur Papa, Lin. (King of the Vultures, Latham) fig. 28 . Vultur Gryphus (Great Vulture of the Andes), fig. 30, which habitually prefers an elevation at which the mercury of the barometer sinks to about sixteen inches. ( 1 )

The Percriopteri have the beak thin, long, and swelled above. Its head only, and not the neck, naked of feathers. These are birds of a moderate size, and their force does not approach that of the Vultures properly so called. They are therefore much more eager after carrion and all sorts of offal, which attracts them from a great distance. 'They do not even refuse excrements. Vultur Percnop. (Egyptian Vulture, Alpine Vulture, Latham), fig. 27. Vultur Aura (Turkey Buzzard, Latham).

\section{GENUS III. FALCO.}

\section{SUB-GENERA.}

1. Nobiles.

A sharp tooth at Second feather of each side of the point the wing the longest. of the beak. Fig. 35. Wings as long and longer than the tail.

2. Hiero-Falco, Cuv.

A festoon, instead of Tail longer than the a tooth, on each side wing, which is the of the point of the same as that of the beak. Fig. 33 .

Nobiles.

3. IGNOBILES.

A. slight festoon in Fourth feather of the middle of the beak. the wing the longest. Fig. 34 . p. 21.

(1) I expect that the Vulture of Ashantee will form a subdivision in the Sarcorcamphi, which have hitherto only been found in America. Its cera is crowned with a caruncula, which, when the bird is flying, is small, bat when it is seeking food, is so much elongated as to hang over the tip of the beak; when in the act of feeding, or when satiated, it hangs on one side to the length of two inches. This caruncula, and the skin of the head and neck, is wrinkled like that of a Turkey, and generally of a deep red, but sometimes of a pale livid blue. The plumage is dark brown, and it performs the same offices as the Percnopterus. 
The Nobiles, or Falcons properly so called, are the most courageous in proportion to their size, a quality which proceeds from the strength of their beak, talons, and wings. Their beak, curved from its base, has a sharp looth on each side of its point; and the second pen feather of their wings is the longest, the first being also nearly as long, which renders the entire wing longer, and more pointed. Some peculiar habits result from this. The length of the pen feathers weakens their vertical effort, and renders their flight in a calm atmosphere very oblique forwards, which obliges them, when they wish to rise in a straight line, to fly against the wind. These are the most docile of all birds, and the most serviceable in the art of falconry; being taught to pursue the game, and to return when called. They all have their wings as long or longer than the tail. (1)

Falco Communis, Gm. (the Common Falcon, Yearling Falcon, Haggard Falcon, Lath.) - Falco Subbuteo, (Hobby Falcon, Lath.) etc. etc.

The Sacred Falcons have the pen feathers of the wings as in other Noble Birds, all of whose inclinations they also evince; but their beak has only a festoon, like that of the Ignobiles. Their tail, long and spread, evidently surpasses their wings, although the latter are very long. Their short and reticulated tarsi are covered with feathers one third of their length. Falco Candicans, (Speckled Partridge Hawk, I ath.)

The Ignobiles (so called because they cannot well be employed in falconry,) are a more numerous tribe than that of the Nobiles, and more necessary to subdivide. The longest pen feather of their wings is almost always the fourth, and the first is very short, which produces the same effect as if their wing had been obliquely chopped off at the end, whence a weaker flight ensues. In all other respects they are equal, except that their beak is not so well armed, because there is no lateral tooth near its point, but only a slight festoon in the middle of the length.

(1) Beak strong; very short; inferior mandible sloped; nostrils wide; feet strong; toes strong, armed with curved and sharp nails; the first remex of the wing short, of equal length with the third, the second the longest. They nourish themselves with living prey, without ever feeding upon dead, and shew much address either in seizing or surprising it: they pursue birds at full speed, or fall perpendicularly upon them; and like to nest in rocks or in ruins of houses.'Tem. 


\section{SUB-GENUS III. IGNOBILES.}

TRIBES.

1. Aquila, Briss. E $\mathrm{A}_{\mathrm{A}}$ GLES.

Beak very strong, straight at its base, curved only towards the point. Fig. 32. p. 24.

2. Astur, Bechstein. Damalion, Savigny. Autours, Cuv.

Beak curved from the base. p. 26 .

Wings shorter than the tail.

3. Mruvus, Bechstein.

\section{KrTE.}

Tarsi short, toes and nails feeble.

Beak curved from the long.

Wings excessively Tail forked. base, but disproportionately feeble.Fig.36.p.26.

4. Pernis, Cuv.

Beak as Milvus.

Interval between the eye and beak covered with close scaly fea- lated.

thers; and not naked or merely hairy as in all the others of the Genus Falco.

5. Buteo, Bechstein. Buzzards, Lath.

Interval between the eye and beak naked. long as the tail.

Tarsi half covered Wings long, but tail with feathers, reticu- not forked.

6. Circus, Bechstein.

A collar on each side of the neck, formed by the ends of the feathers covering the neck. Fig.

34.
Tarsi longer than in the tribe Buteo; the wings the same.
Tail even. 
7. Serpentarivs, Cuv. Gypogeranus, Illiger.

Beak cleft; eyebrows projecting; orbit of the eye naked of feathers. Fig. 37.

The only Birds of this Order with the from the occiput. The tarsi exceedinglylong; two middle feathers of plated. Fig. 38. Toes the tail considerably short in proportion. surpass the others.

Eagles, which form the first tribe, have a very strong beak, straight at the base, and only curved towards the point. It is amongst these that we find the largest species and the most powerful of all Birds of Prey. (1)

The Astur tribe, which forms the second division of Ignobiles, have, like the two last divisions of Eagles, wings shorter than the tail; but their beak curves from its base, as in all those which follow. ( 2 )

Kites have the tarsishort, the toes and nails weak, which, added to a beak equally disproportionate to their size, makes this tribe the most cowardly of the whole Genus; but they are distinguished by their excessively long wings, and by their forked tail, which gives them a most rapid and easy flight. Some have the tarsi very short, reliculated, and half covered with feathers. (3)

(1) Head flattened on the top, covered with elongated feathers. Beak very much crook'd, a long and very sharp point. Nostrils lateral, transverse, sloped; feet strong, armed with powerful nails, very much crook'd. Wings long, the first, second and third remiges the shortest; the first very short, the fourth and fifth the longest. They seize living prey with their talons, and take it to their young; when pressed with hunger they fall upon carrion.-Tem.

(2) Beak strong, superior mandible bearing a strongly marked tooth. Nostrils rather oval, wings two-thirds of the length of the tail; first remex much shorter than the second, the third almost equal to the fourth, which is the longest. Toes long, the middle much surpassing the lateral, nails much curved, and very sharp. Their flight is rapid, without shaking their wings much; it is only in pairing time that they describe circles in flying; they are cunning and malicious, and seize their prey flying; they mostly inhabit large woods, particularly those in the neighbourhood of rocks.-Tem.

(3) Beak curved at its base; feathers of the head elongated and terminated in a point ; mouth cleft as far as under the eyes; nostrils oblique, their exterior edge marked with a fold; the first remex of the wing shorter than the sixth, the second a little shorter than the fifth, the third almost equal in length to the fourth, which is longer than all. In a state of repose they have an awkward attitude, but their flight is elegant; they seem to swim in the air, describing circles; they do not seize their prey when flying, but they fall upon it from above, when it is resting on the ground or on some elevation. Tem. 
The Pernis tribe has, with the weak beak of the Kite, a very peculiar character, which is, that the interval between the eye and the beak, which in all the others of the Genus Falco is naked, or only presenting a few hairs, is covered with very close fealhers, cut into scales. Their tarsi are half feathered in the upper part, and reticulated; they have an even tail, long wings, and the beak curved from its base, like all those which follow. Falco Apivorus, (Honey Buzzard, Lath.) La Bondree Huppée de Java.

The Buteo tribe has the wings long, the tail equal, and the beak curved from its base, the interval between which and the eye is without feathers; the feet strong. There are some with the tarsi feathered even to the toes (F. Pennaius); but the greater number have the tarsi naked and plated (F.Buteo. Bacha, Vail.). They are distinguished from $\boldsymbol{E}$ agles by their beak, curved from its base: from Aulours, or Eagle Autours, by tarsi covered with strong feathers, and by their long wings. (1)

The $\boldsymbol{C}$ ircus iribe differs from the $\boldsymbol{B}$ uteo by more elevated tarsi, and by a species of collar, formed on each side of the neck by the ends of the feathers which cover the ears; fig. 34. (2) Falco Pygargus, (Ring-tailed Hen-harrier, Lath.) Falco Rufus (Harpy Falcon, Lath.)

The Serpentarius, or Secretary, is an African Bird of Prey, with the tarsi at least double the length of all the other Birds of this Family, which has made naturalists class it with the Grallæ; but its thighs, entirely covered with feathers, its beak crook'd and cleft, its projecting eyebrows, and all the details of its anatomy, place it in the present Order. Its tarsi are plated; its toes short in proportion; the orbit of its eye naked of feathers; it has a long stiff occipital crista, and the two middle pen feathers of its tail greatly surpass the others. It inhabits the sterile and open places in the neighbourhood of the Cape, where it pursues reptiles on foot, and has nails worn by dint of walking; fig. $3_{7}, 3_{0}$. It principal strength is in its feet. (3)

(1) Beak weak, with a rounded tooth (not very apparent); the head large; the body massive and heavy. Feet with short tarsi; thighs breeched. Wings of a moderate length, the four first remiges sloped, the first very short, the second and third less long than the foursh, which is the longest. They have a heavy flight, do not take their prey flying, but generally lay wait for it in ambush on a tree. Tem.

(2) Beak small, superior mandible curved from its base, bearing \& blunted tooth (not very apparent) at the root of the beak, and some straight hairs which hide a part of the cera. Nostrils open. Feet with very long and thin tarsi; body slender; tail long. Tem.

(3) This Bird was introduced into the French West India Islands, to destroy the numerous serpents. 


\section{TRIBE I. AQUILE.}

DIVISIONS.

\section{Eagles proper, Cuv.}

Tarsi covered with Wings as long as the feathers to the bases of tail.

the toes, reticulated.

2. Halietus, Savigny. $\Lambda$ igtes Pêcheurs, Civv.

Fisuing $\mathrm{H}_{\mathrm{Aw}} \mathrm{ws}, \mathrm{La}$ tham.

Tarsi covered with feathers half way down, the remaining half plated. p. 25.

3. Harpyis, Cuv. Short-

Winced Fishing EA- $_{\text {- }}$ GLES.

Tarsi very large and strong, half feathered, the tail. reticulated.

4. Monpinus, or Aigle Autour, Cuv.

Tarsi long and slim, Ditto. half feathered. p. 25.

Ditto.

3. Crmindrs, Cuv.

Tarsi very short, reticulated, half covered

Ditto.

Very strong beak and nails. with feathers in front.

Toes weak.

Nostrils almost closed, or like a fine slit.

Eagles Proper have their tarsi feathered to the root of the toes; they live in mountains, and pursue Birds and Quadrupeds; their wings are as long as their tails; their flight is as high as rapid, and their courage surpasses that of all other birds. Falco Fulvus, (Black Eagle, Ring-tailed Lagle, Lath.) Falco Chrysaetos, (Gold Eagle, Gold Adler, Lath.) etc.

The Harpies, or Fishing Eagles with short wings, are American Eagles; their tarsi are very large, very strong, reticulated, and half feathered, like the Fishing Eagles properly so called, from which they only differ by the shortness of their wings; their beak and nails are even stronger than in any other tribe. Falco Harpyia (Oronooko Eagle, Lath.).

The Cayenne Falcon of Latham is a Cymindis. 


\section{DIVISION II. HALIETUS.}

1. Haliateus. Prop.

\section{SUB-DIVISIONS.}

Nails grooved underneath, as in all the other Birds of Prey.

2. Pandion, Savigny. Balbusards, Cuy.

Nails round underneath.

3. Caracatía.

Part of the side of the head, and sometimes of the neck, naked of feathers. Fig. 32.

The first Sub-division have the same wings as the Eagles Proper, but the tarsi are only covered with feathers on their upper half and half-plated on the other. They frequent the borders of rivers and the sea-shore, and live mostly on fish. Falco Ossifragus, (Sea Eagle or Osprey; Lath.) Falco Leucocephalus (White-headed Eagle, Bald Eagle, Lath.).

The Pandions have the beaks and feet of the former, but their nails are round underneath, whilst in other Birds of Prey they are hollowed into a groove; their tarsi are reticulated, and the second feather of their wings is the longest. We know but one species, spread through almost the whole of the globe on the banks of fresh waters, with few variations in the plumage.

America produces Fishing Eagles with long wings, like the preceding, where a larger or smaller portion of the sides of the head, and sometimes of the throat, is naked of feathers. They give them the common name of Caracara. Brazilian Kite, Lath. etc.

\section{DIVISION IV. MORPHNUS.}

\section{SUB-DIVISIONS.}

1.

Tarsi naked, and plated.

2.

Tarsi covered with feathers all the way down.

1. Urubitinga (Brazilian Eagle, Lath.). 2. Urutaurana (Crowned Eagle, Lath.). 


\section{TRIBE II. ASTUR.}

\section{DIVISIONS}

1. Astur proper.

Tarsi plated, and rather short.

2.

Tarsi short, but reticulated.

3. Nisus, Cuv.

Tarsilonger, but plated.

1. F. Palumbarius (Goshawk, Lath.). 2. F. Cachinnans (Laughing Falcon, Lath.). 3. F. Musicus, the only known species of Birds of Prey which sings agreeably. F. Nisus (Sparrow Hawk, Lath.).

\section{TRIBE III. MILVUS.}

\section{DIVISIONS.}

1. Elanus, Savigny.

Tarsi very short, reticulated, covered with feathers half way down. Fig. 40.

2. Milvus proper, $C u v$.

Tarsi stronger, and plated.

1. Le Blac. Le Vaillant. F. Furcatus (Swallow-tailed Falcon, Lath.). 2. F. Milvus (Kite). 


\title{
FAMILY II. NOCTURNE.
}

\section{GENUS I. STRIX.}

\author{
SUB-GENERA.
}

1. Strix, Lin.

Orifice of the ear 'A large circle of fine large. feathers round the eyes. Small collar of scaly feathers.

\section{Noctua, Savigny.}

Orifice of the ear oval, and not much larger than in other small and imperfect. birds. p. 29.

The Sub-genus Strix may be divided according to the egrets, the size of the ears, the extent of the circle of feathers which surrounds the eyes, and some other characters.

Those species which have a large complete disk of fine feathers, encircled by a small collar of scaly feathers, and, between the two, a large orifice of the ear, are more distant in form and manners from the Diurna, than those whose ears are small, oval, and covered by fine feathers which come from below the eye. We observe traces of these differences even in the skeleton. (1)

The Sub-genus Noctua has not the wide and deep conch of the ear, the orifice of which is oval scarcely bigger than that of other birds; the disk of fine feathers is less large and less perfect.

(1) Beak compressed, base encircled by a cera, covered entirely, or in part by rude hairs. Nostrils lateral, pierced on the anterior edge of the cera, rounded, open, hid by hairs directed in front. Iris brilliant; wings a little pointed, the first remiges dentated on their exterior edge; the first the shortest, the second not reaching the extremity of the third, which is the longest; their eyes are dazzled by the light of the sun, but they see very well during the day. The bones, hairs, and feathers of their prey, after the flesh has been well digested, are rejected in little balls.-T'em. 


\section{SUB-GENUS I. STRIX.}

TRIBES.

1. Otus, Cuv.

Egrets raised at will. Conch of the ear Tarsi feathered to extended in a semi- the nails. circle from the beak towards the top of the head, and furnished with a membranous operculum.

2. ULULA.

No Egrets.

Ear and beak of Tarsi feathered to Otus. the nails.

3. Strix, Savigny.

No Egrets.

Beak elongated, Tarsi feathered, but curves only towards only hairs on the toes. the end; ear of Otus.

4. Syrnium, Savigny.

No egrets.

Conch reduced to an Tarsi feathered to oval cavity, not oc- the nails:

cupyinghalf the height of the skull.

Tail short.

5. Bubo.

Egrets.

Conch of the $S y r-$ nium, but the circle of feathers around the eye less marked.

$\$$ Egrets wider, further back and difficultly raised from a borizontal line. (6)

1. Strix Ascalaphus. 2. S. Litturata. 3. S. Flammea. 4. S. Aluco. 5. S. Bubo. Fig. 43. (6) Chouette à aigrettes, Vaill. Fig. 42. 


\section{( 29 )}

\section{SUB-GENUS II. NOCTUA.}

\section{TRIBES.}

1. Sunnia, Dumeril.
A long tail, gradu-
Toes well feathered. ated.

Fig. 44.

2. Nyctea.

Short tail.

3.

Short tail.

Toes feathered.

No egrets.

4. Nudipes. ked.

Toes naked.
Tarsi and toes na-
ed.

5. Scops, Savigny.

Ears even with the head.

Toes naked.

Egrets.

1. Siberian Owl. Choucou, Vaill. Fig. 40. 2. Harfang (S. Nyctea). Fig. 46. 3. Cayennensis, etc. 4. S. Nudipes, Daud. 5. S.Scops. 



\section{$(33)$ \\ ORDER II.}

\section{Passeres.}

THE character of this Order, the most numerous of the whole Class, seems at first to be simply negative, since it embraces all the Birds which are neither Palmipedes, Gralla, Scansores, Accipitres or Gallinacea, comparison, however, presents a great resemblance in their structure, and such insensible passages from one Genus to another, that it is very difficult to establish the subdivisions.

We find the Singing Birds and, consequently, the most complicated inferior larynxes (p. 7 , note 2.) amongst the Passeres.

\section{DIVISIONS.}

1. Exterior toe united to the middle toe by one or two joints only.

2. Exterior toe almost as long as the middle toe and united with it as far as the last joint but one, p. 50 .

\section{DIVISION I.}

FAMILIES.

\section{Dentirostres.}

Beak notched on each side of the point. Fig. 47 , p. 34 .

2. Fissirostres.

Beak short, [íwide, flattened horizontally, slightly crook'd, without notch, deeply cleft. Fig. $77,(1)$ p. 41 .

(1) Their mouth is consequently so very large that they easily swallow the insects which they take in their flight : being entirely insectivorous, they quit us in winter. They approach the tribe Muscicapa, and especially the Procnias, whose beak scarcely differs but by the notch. 


\section{Conirostres.}

Beak strong, more or less conical, without notch. Fig. 78, p. 42 .

\section{Tenuinostres.}

Beak slim, elongated, more or less arched, without notch. Fig. 91, p. 48 .

\section{FAMILY I. DENTIROSTRES.}

\section{GENERA AND SUB-GENERA.}

\section{Lanius, Lin.}

Beaks conical or compressed, more or less crook'd at the end.

a. L. Proper. Shrikes.

Beak triangular at base, compressed at the sides.

a Beak with the superior edge arched. (1)

$$
\begin{aligned}
& \text { \& } \quad . . \quad \text {.. } \quad . . \quad \text { straight, crook'd only at the end. Fig. } 49 . \\
& \gamma \quad \text {.. } \quad \text {. } \quad . \quad \text {.. } \quad \text {.. lower mandible much swelled. Fig. } 50 .
\end{aligned}
$$

\section{b. Ocypterus, Cuv. Lan- GRAYEN.}

Beak conical, rounded, without edge, point very fine, slightly notched on each side. Fig. 164, bis.
Wings, as long and longer than the tail, affording the same flight as the Swallows.

(1) Those in which the point is strong and much crook'd, possess a courage and cruelty which has induced many Naturalists to associate them with the Accipitres or Birds of Prey (See p.14). The beaks of the Lanii of the other parts of the world diminish in size and become gradually weaker in their points, according to the species, so that it is impossible to establish a limit between this Sub-Genus and that of Turdus : amongst those with the stronger beak is the Fiscal, Fig. 47 ; a mongst those approaching the Turdi, the Oliva. Fig. 48. 
c. Barita, Cuv. Cassicans, Buff.

Beak large, conical, straight, round at its base, sloping out the feathers of the forehead in a circle, rounded on the back, compressed at the sides, the point crook'd and notched laterally. Fig. 55 .

d. Psaris, Cuv. BegarDEs, Buff.

Beak conical, very large, round at the base, not sloping out the forehead, point slightly compressed and crook'd.

e. Graucalus, Cuv.

Choucaris, Buff.

Beak less compressed than in the Lanii pro-

Feathers sometimes covering the nostrils. per, arched equally in its whole length; the commissure (1) a little arched. Fig. 156.

\section{$f$. Bethylus, Cuv.}

Beak large, short, swelled in every part, slightly compressed towards the end. Fig. 53 .

2. 'TAnagra, $L i$ h. TANAGERS.

Beak strong, conical, triangular at the base, slightly arched at the upper edge.

a. T. Euphones. BouVREUILS.

Beak short and presenting, when viewed vertically, an enlargement on each side of the base. Fig. 54 . short.

Wings and flight

(1) Commissura labiarum. Fig. 154, $c$. 'Tail short in propor-
tion. 
b. T. Gross-beaKs.

Beak large, swelled, as broad as deep, and the back of the upper mandible rounded.

\section{c. T. Proper.}

Beak shorter than the liead, as broad as deep, upper mandible arched. Fig. 56.

d. T. Lor iots.

Beak arched, sharpedged.

$e$. T. Cardinals.

Beak a little swelled, a projecting obtuse tooth on the side. Fig. 57.

\section{f. T. Rhamphocéles.}

Inferior mandible enlarged towards the base. Fig. 59.

3. Muscicapa, Lin. Fly Catchers.

Beak depressed horizontally, with hairs at the base, and the point more or less crook'd and notched.

a. Tyrannus, Cuv.

Beakstraight, long. very strong, upper culminating edge (1) straight, blunt, the point suddenly crook'd. Fig. 61 .

The larger species carnivorous.

Several are ornamented with crests and long feathers in their tail. pressed, twice as broad as deep, culminating edge very obtuse, point feeble, long hairs at the base. Fig. 6\%.

(1) "Arile supérieure." Fig. 157, a. 
c. Muscicapa, Cuv.

Mustachios shorter and beak narrower than in the Muscipeta, point a little crook'd. Fig. 157, bis.

d. Gymnocephalus, Geoff. Bald-HEAds.

Beak of Tyrannus, but the culminating edge more arched and a great part of the face naked of feathers. Fig. 60 . Choucas chauve, Buff.

e. Cephalopterus, Geoff.

Base of the beak furnished with a bunch of raised feathers in the form of a parasol. Fig. 101. C. Ornatus.

4. Ampelis, Lin. CoTINGA.

The depressed beak of the Muscicapa, but shorter in proportion, broad, and slightly arched.

\section{a. Piauhau.}

Beak stronger and more pointed. Fig. 64.
b. C. Proper.
Beak weaker.
c. Cembepyris, Cuv. Ca- TER PILLAR-CATCHERS.

Stems of the feathers of the rump elongated, stiff and pointed.

\section{d. Bombycivora, Tem. Chatterers.}

Insectivorous. America.

Wings of males coloured with brilliant azure and purple in the pairing season.

Tail a little forked in the middle, graduated at the sides. No brilliancy of colour. Africa. India.

Ends of the stems of the secondary feathers of the wing enlarged into a smooth, oval, red disk. 


\section{e. Procnias, Hofm.}

Beak weaker, more depressed, and cleft to below the eye. Fig. 162.

\section{$f$. Gymnoderes, Geoff. NAKED-NECKS.}

Beak stronger.

5. Edolius, Cuv. DroxGo.

Beak depressed and sloped at the end, the culminating edge sharp, both mandibles slightly arched in their whole length. Fig. 65.

\section{Turdus, Lin.}

Beak compressed and arched, but without crook, and the notches less marked than in the Lanius. Fig. 96.
$a$. Black birds.

b. Thrushes.
Neck partly naked and the head covered with velvet-like feathers.

\section{Nostrils covered} with feathers and long hairs like mustachios.
I with black, and with forked tails. Insectivorous.
Generally frugivorous : habits solitary.

Colours unịform, distributed in large masses.

Plumage speckled, marked with small black or brown spots.

7. Рувриo-Сorax, Cuy.

Beak of Turdus, but nostrils covered with feathers. Fig. 102. Sicrin.

\section{Oriolus, Lin. (1)}

Beak of Turdus, but Feet shorter in prorather stronger. portion. Fig. 67.

(1) Linnæus and his successors united them to the Cassicans, which they resemble only in their colours. 
9. Мчothera, Illig. Ant Thrushes.

Legslong. Fig.107.bis. Tail short.

10. Crnclus , Bechst. Water Ouzels.

Beak compressed, straight, mandibles equally deep, almost in a line, sharpening towards the points, and the superior scarcely arched.

\section{Piriledon.}

Beak compressed, Nostrils large, coAfrica and the coun. slightly arched in its whole length. vered by a cartilagi-- tries bordering on the nous scale; tongue ter- Red Sea. minated by a pencil of hairs. Fig. 69 and 71 , (P. carunculata).

12. Gracula, Cuv.GraKLES.

Beak compressed, Feathers of the head generally narrow and a naked space around the eye.

very slightly arched and notched : the commissure forming an angle as in the Sturnus. Fig. 73. G. carunculata.

13. Manura, Shaw. LXRE-TAILS.

Beak triangular at the Nostrils large, mem-

The males with base, elongated, a little branous, and partly large tails of 16 feacompressed. Fig. 109. covered with feathers. thers, the 2 exterior curved like a lyre. (1)

(1) They have been referred by some authors to the Gallinacea, from their size, but their feet are evidently those of Passeres. 
14. PIPRA, Lin. M MANAKINS.

Beak compressed, deeper than brőad; nasal canals large.

a. Rupicola.

A. double crest of feathers on the head, like a fan. Fig. 111.

b. Pipra, Cuv.
2 exterior toes united nearly half their America.
Large.

Small. Fig. 68.
Remarkable for their lively colours : live in troops in damp forests.

\section{Motacilla, Lin.}

Beak straight, slender, like a bodkin.

a. SAXicola, Bechst.

Beak depressed, rather large at the base. ground.

Fig. 74 .

b. Syivia, Wolf. FiceDULA, Bechst.

Beak rather narrower at the base. Fig. 165.

Solitary : nest in holes. Live on insects, worms,

c. Gurruca, Bechst.

Beak straight, slim, a little compressed in front, the culminating edge a little curved towards the point. Fig. 158.

$\alpha$ (Nightingales.) Nest in trees.

$$
\beta
$$

$d$. Regulus, $C u v$. Wrens.

Beak perfectly conical and very sharp ; its sides, when viewed vertically, appearing rather concave. Fig. 75 .

\section{$e$. Troglodytes, $\mathrm{Cuv}$.}

Beak still slighter than in the Regulus and a little arched. 
f. Motacilla, Bechst.

W AG-TAILS.

A long tail, which they move up and down incessantly.

a. Lavandiekes.

Nail of the great toe curved as in all the other Motacillo except the $B u$ dytes.

f. Budytes.

Nail of the great toe elongated and a little arched.
Legs long ; the scapulary feathers sufficiently long to cover the end of the wing when folded.

g. Anthus, Bechst.

Beak slim. long.

Nail of the great toe

Scapulary feathers of ordinary length.

Live in pastures ; pursue insects.

\section{FAMILY II. FISSIROSTRES.}

GENERA AND SUB-GENERA.

\section{$\int$ Diurnce. Close, firm, plumage.}

1. Hinundo, Lin.

$$
\begin{aligned}
& \text { Wings extremely } \\
& \text { long, flight rapid. }
\end{aligned}
$$

a. Apus, Cuv. Cypselus, Illig. Martins.

Feet very short; the great toe directed forwards and the middle and exterior toes with only three joints like the inner.

Tail forked.

Sternum without notch (1). Nest in holes of walls and rocks; climb along the smoothest surfaces.

\footnotetext{
b. Hirundo, Cup. SwalLows.

Toes and sternum as in the generality of Passeres.
}

(1) Ordinarily there is one notch on each side of the lower edge. 
a Tail forked. (1) \{ Toes feathered.

$\beta$ Tail almost square.

$\gamma$ Tail square with the pen feathers terminating in a point.

SS Nocturna. Light, soft, plumage shaded with grey and brown.

2. Caprimulgus, Lin.

Goat-suckers.

Beaks more cleft, with strong mustachios; nostrils, at the base, in the form of small tubes; eyes large. Fig. 77.

The exterior toes Feet short, tarsi feawithonly 4 joints, and thered. The air inall the toes united by a gulphed in their large short membrane. beak when flying produces a peculiar buz.

a. Nail of the middle toe dentated on its inner edge.

b. Nail not dentated. Tail forked.

3. Podarges.

Beak stronger. Fig. No membrane be163.

Tail square. tween the toes.

\section{FAMILY III. CONIROSTRES.}

GENERA AND SUB-GENERA.

1. A tauda, Lin. Larks.

Nail of the great toe Granivorous; frestraight, strong, and quent the ground. much longer than the others.

a. Beak straight, moderate, pointed.

b. Beak so large as to approach that of the Fringilla. Fig. 78.

c. Beak elongated, a little compressed and arched, approximating them to the Upupa and Promerops.

(1) The Salangane (H. esculenta, Lin.), a small species of the Indian Archipelago, is celebrated for its nest of a whitish gelatinous substance, made, as it is believed, from the spawn of fish or some scum from the surface of the sea : the restorative virtues attributed to these nests have made them an important article of commerce in China; they are dressed like mushrooms. 
2. Parus, Lin. Titmice.

Beak slender, short, Small hairs at the conical, straight. Fig. base of the beak, and 70. the nostrils hidden by feathers.

a. Parus proper.

b. Moustaches.

'The end of the superior mandible curving on the other.

c. Remiz.

Beak more slim and pointed.

Display great art in forming their nests, in the shape of purses or bottles.

3. Emberiza, Lin. BunTINGS.

Beak conical, short, A projecting, hard, straight, superior man- tubercle in the palate. dible narrower, entering within the inferior. Fig. 72.

\section{Fringilla, Lin.}

Beak conical, more or less large at the base, but the commissure not angular.

\section{a. Ploceus, Cuv. Tisse- Rins. Weavers.}

Beak as large as in the Cassicans, but the commissure straight and the superior mandible slightly swelled.Fig.79.

The greater part of those of the Old Continent make their nests with much art, interlacing sprigs of herbs (1).

\section{b. Pyrgita, Cuv.}

Beak shorter, and a little swelled towards the point only. Fig. 159.

(1) The nest of the Toucnam Courvi (Loxia Philippina) is suspended, in the form of a ball, with a vertical canal, open underneath, which communicates sideways with the cavity containing the young. 

c. Fringilla, Cuv. Chaf- FINGHES.

Beak less arched than in the Pyrgita, and a little stronger and longer than in the Linaria. Fig. 103. 104.

\section{d. Carduelis, Cuv.}

Beak conical and entirely free from swell. Fig. 80 .

\section{a. Chardonnerets.}

Goldfinches.

Beak longer and sharp.

ß. Linaria, Bechstein. LinNets.

Beak shorter and obtuse.

e. VIdua, Cuv. W IDow Birds.

Beak of Linaria, sometimes a little swelled at the base. Fig. 95 .

\section{f. Cocothraustes. Gross- BEAKS.}

Beak conical and large.

\section{g. Pitylus, Cuv.}

Beak very large, a little compressed, arched above, and sometimes with a projecting angle in the middle of the edge of the upper jaw.

h. Pyrraula. BullFINCHES.

Beak rounded and swelled in every part. Fig. 81 .

๖. Loxin, Briss. CrossBILLS.

Beak compressed; the mandibles so much curved that the points cross each other. Fig. 82.
T'ectrices superiores of the tail excessively elongated in the males. 
6. Conythus, Cuv. HARD-BEAKS.

Beak swelled in every part; the point of the upper curved over the lower mandible. Fig. 85.

7. Courus, Gm. Courrs.

Beak short, thick, conical, a little compressed; the two mandibles arched without crossing.

8. Glaucopis, Forster: Calluas, Bechst. W ATtTLF-BIRds.

Upper mandible swelled.

The great toe has Pen-feathers of the the power of direct- tail graduated, and veing itself forwards. ry long.

A fleshy caruncula under the base of the beak. Fig. 83 .

9. Buphaga, Briss.

BeEf-eateris.

Beak cylindrical at the base, swelling towards the middle; the point blunt. Fig. 84.

10. Cassicus, Cup. CasSICANS.

Beak large, conical, enlarged at the base, sharpened into a point; the commissure in abroken line or forming an angle as in the Sturni.

a. Cassicus proper.

Base of the beak rises on the forehead and slopes out the feathers in a semi-circle.Fig. 100.

b. Icterus.

Slope of the forehead angular and the beak arched.

Small round nostrils, pierced at the sides. 
c. Xanthornus.

Slope angular, but beak straight.

d. Dacnis, Cuv. Prt-Pits. Buff.

Beak conical and sharp.

They form a passage to the Sub-Genus $R c$. gulus.

11. Sturnus, L. Stares, Starlings.

Beak of Xanthornus, but depressed towards the point. Fsg. 94.

Relieve the cattle from insects, which they feed on; quit us in winter.

12. Sitta, Lin. NutHATCHES.

Beak straight, prismatic, pointed for cutting Hind toeverystrong.

Tail affords no support in climbing. the bark to get at the worms. Fig. 98.

\section{Convus, Lin.}

Beak strong, more or less flattened at the sides.

Nostrils covered by stiff hairs, directed forwards.

a: (1) Corvus proper.

Beak stronger in proportion and the culminating edge more arched than in the others. Fig. 86. C. Corax.

b. Pica, Cuv. Magpies.

Ditto. Fig. 63 .

c. Garrulus, Cuv. Jays.'

Tail round or square.

Mandibles rather short and terminating in a sudden curve. Fig. 87.

Tail long and graduated.

(1) The Corbeau ( $C$. corax, Lin.) in Cuvier, is our Raven; the Corneille (C. corone Lin.), the Carrion Crow; the Freux (C. frugilegus, Lin.), the Rook : the Corneille Mantelée $(C$. cornix, Lin.), the Hooded Crow; the Choucas ( $C$. monedula, Lin. ', the Jackdaw.-Regne Animal, t. i. p. 397. 
d. Caryocatactes, Cuv. Nut-crackers.

Mandibles equally pointed, straight, without curve. Fig. 58 .

\section{e. Temia.}

Beak round, the base furnished with velvetlike feathers. Fig. 108.

\section{Coracias, Lin. Rot-} LERS.

Beakstrong, compressed towards the end, the point a little crook'd. thers.

Nostrils oblong, not covered by the fea-
Feet short and strong. Two notches on each side of the lower edge of the sternum.

\section{a. Coracias Proper.}

Beak straight, and deeper than broad. Fig. 88.

\section{b. Colaris, Cuv.}

Beak shorter, more arched, and enlarged at its base, so as to be broader than deep. Fig. 89.

c. Eulabes, Cuv.

Beak of Coracias.
Head partially naked of feathers, with fleshy prominences in stead. Fig. 116.
Velvet-like feathers, advancing to the edge of the nostrils as in the Paradiscea.

15. Paradis瓜a, Lin. Birds of Paradise. Beak of Corvus. Fig. 110 .

Feathers covering the nostrils, velvet-like, and often of a metallic lustre; those of different parts of the body singularly developed. 


\section{FAMILY IV. TENUIROSTRES.}

\section{GENERA AND SUB-GENERA.}

1. Upupa, Lin. Hoopoes.

a. Fregrlus, Cuv.

Beak longer than the head. Fig. 155.

Nostrils covered with feathers directed forwards.

b. UPUPA PROPER.

A double row of feathers on the head, erected at will. Fig. 118.

c. Promerops, Briss.

Tongue extensible No crest. and forked. Fig. 115.

d. Epimachus, Cus.

Scaly or velvet-like feathers covering a part of the nostrils. Fig. 161 .

2. Certhia, Lin. CreepERS.

a. Certhia proper.

Climb trees like the Pici, using their tail as a support, the pen-feathers of which are worn and terminate in stiff points. Fig. 90, bis.

b. Dendrocolaptes, $\mathrm{Her}$. Picucules.

Beak stronger, and broader transversally.

c. Tichodroma, Illig.

Beak triangular, depressed at the base, very long and slim. Fig. 117.

Ditto.

Tail not worn.

T'ail very long; live on the juices of flowers.

d. Nectarinia, Illig. SuGAR-BIRDS.

Beak moderately long, arched, pointed and compressed as in the Certhir. Fig. 114. 
e. Diczum, Cuv.

Beak sharp, arched, Tail not worn. not longer than the head, depressed and enlarged at the base. Fig. 113.

$f$. Hoerotaria, Vaill.

Beak extremely elongated, curved almost in

Ditto. a semi-circle. Fig. 93.

g. Cinnyris, Cuv. SugarEATERS.

Beak long and slim, the edges of both mandibles finely dentated; tongue terminated in a fork and elongating. Fig. 93.*

Ditto. Live on flowers only.

3. 'Tnochinus, Lin. HumMING-BIRDS.

Beak long and slim; Plumage of a metal- Live on flowers and tongue elongating and lic lustre. insects. No notches in bifid.

the sternum.

a. Colibris.

Beak arched. Fig. 99.

$T$. cinereus.

$b$. ORthorhynchus, $L a-$ cep. Fly-BIRDs.

Beak straight. Fig.97. $T$. minimus. 


\section{DIVISION II. SYNDACTYL.E.}

GENERA.

1. Merops. Lin. W AsPeaters. BeE-eaters.

Beak triangular at its base, elongated and slightly arched, terminating in a sharp point. Fig. 119.

2. Prionites, Illig.

Beak stronger, edges indented, tongue barbed. Fig. 92 .

3. Alce Do, Lin. K $\mathrm{KNG}_{\mathrm{LN}}$ FISHERS.

Beak longer than $M e-$ rops, straight, angular, pointed; tongue very short. Fig. 120.

4. CEyx, Lacép.

Beak as Alcedo.

Feet short. Fig.119. Two notches on each side of the lower edge of the sternum.

Feet shorter than Merops. Fig. 120.

Tail very short. Sternum as Merops.

Inner toe not apparent.

5. Touvs, Lin. Todres.

Beak flattened horizontally, obtuse at its extremity. Fig. 106.

6. Buceros, Lin. HornBILLS.

Beak enormous, notched, surmounted by prominences sometimes equalling it in size. Fig. 105. C. unicornis. 


\section{ORDER III.}

\section{Scansores. Climbers.}

These are Birds whose exterior toe directs itself backwards like the great toe, affording a very solid support, by which some of them profit for clinging to and climbing the trunks of trees. They have consequently received the name of Climbers, although it is not strictly applicable to all; whilst several Birds which climb do not belong to this Order by the disposition of their toes.

The Scansores generally rest in the holes of old trees : their flight is moderate; their food, like that of the Passeres, generally consists of insects or fruits, according to the strength of their beak; some, as the Pici, have peculiar means for obtaining it.

The sternum of most of the Genera has two notches behind (Fig. 121), but in the Parrots there is only a hole (Fig. 122), not unfrequently filled up.

\section{GENERA AND SUB-GENERA.}

1. Jicamar. Galbula. Briss.

Beak elongated, pointed, upper culminating edge sharp.
Feet short, exterior toes united in a great part of their length.
Plumage of a metallic lustre. Live isolated in damp woods. Insectivorous.

America.

a. Beak longer and perfectly straight. Fig. 123. G. ruficauda.

b. Beak shorter, larger, and a little arched. Fig. parated.

Anterior toes more seIndian Archipelago.

124. Jacamerops or $G$. grandis.

c. No upper culminating edge to the beak. Fig. 126. Great Jacamar, Vaill. 
2, Picus, Lin. WoodPECKERS.

Beak long, straight, angular, compressed in slim ar a a wedge at the extremity, for clearing the curve backwards. (1) barks of trees.

Tail with 10 penfeathers, the stems stiff and elastic, supporting them as a buttress in climbing. Fig. 125.

a. P. Proper.

Fig. 125.

b. Picoïne, Lacép. TriDACTYLE.

Only 2 toes before and 1 behind. Fig. 127.

$c$.

Beak slightly arched, approaching that of the Cuckows. Fig. 129.

3. Yunx, Lin. Torcols. WRY-NECKS.

Beak straight, pointed, almost round and but without spines. withoutangles. Fig. 166.

Tongue protractile, Tail with pen-feathers of the ordinary form.

\section{Cuculus, Lin. \\ Cuckows.}

Beak moderate, somewhat cleft, compressed, Tail rather long. slightly arched.

a. C. Proper.

Beak of moderate length. Fig. 130. (2)

Tarsi short. Fig. 132. thers.

Birds of passage. Insectivorous.

b. Couns. Vaill.

Tarsi long. Fig. 134.

(1) The tongue, pushed out by the elastic cartilaginous prolongations of the os hyoïdis (Fig. 128, $\boldsymbol{c}$.), elongates considerably beyond the beak (Fig. 125) and is imbued with a viscous juice, furnished by large salivary glands : it is drawn in by two muscles, rolled like ribbands around the trachea, the cornea of the os hyoid is reascending under the skin and upon the head as far as the superior base of the beak (Fig. 128.), and the sheath of the tongue folding on itself at the bottom of the gullet.

(2) There arc $\Lambda$ frican species with the beak more depressed (Fig. 131. C. auratus) and others with the beak déper vertically. (Fig. 132.C. Tachirou.) 
6. Coucals, Vaill. CenTROPUS, Illig.

Nail of the great toe long, straight, pointed. Fig. 135 .

d. Gourols. Vouroudrious, Vaill.

Beak large, pointed, Nostrils pierced obscarcely arched. Fig. liquely in the middle. thers.

Tail with 12 pen-fea137.

e. INDicators, Vaill. HoneY Guckows.

Beak short, deep, almost conical. Fig. 136.

Ditto.

\section{$f$. Barbacous, Vaill.}

Beak conical, elongated, slightly arched at the end. Fig. 138.

Fine feathers or stiff hairs at the base of the and forked.

Tail a little graduated beak.

5. Malconis, Vaill.

Beak very large, round at the base; a naked space around the eye.

$a$.

$b$.

6.ScYthrops, Lath.PsitTACEOUS HoRN-BILLS.

Beak larger and longer than the Malcohas, cle around the eye with two shallow longi- naked.

tudinal furrows on each side. Fig. 141.

7. Bucco, Lin. BAR BETS.

Beak large, conical, swelled at the sides of hairs, directed forthe base.
Nostrils round, and towards the base of the beak. Fig. 139 .

Nostrils narrow, and near the edge. Fig. 140. wards; 1 behind each

\section{Ceylon.}

Frugivorous. nostril, 1 on each side of the base of the lower jaw, and the 5th under the symphysis.

New-Holland.

Wings short. 
a. Pogonias, Illig. BarBICANS.

Two deep notches on each side of the upper mandible, and its culminating edge blunt and arched ; the lower mandible furrowed transversally underneath. Fig. 142.

\section{b. Bucco proper.}

Beak simply conical, slightly compressed; culminating edge blunt, and a little raised in the middle. Fig. 143.

\section{c. Tamatias.}

Beak more elongated and compressed, with the extremity of the upper mandible curved downwards. Fig. 144.

\section{Trogon, Lin. Curu- cUIs.}

Beak short, broader than deep, curved from the base; upper culminating edge arched, blunt, and the lateral edges notched. Fig. 145 .

9. Crotophaga, Lin. Anis.

Beak large, compressed, arched, without notches, having a vertical sharp crest. Fig. 146.

10. Riamphastos, Lin. Toucans.

Beak enormons, almost as thick and as long as their body, slight with barbs on each

and cellulous interiorly, side, like a feather. arched towards the end, irregularly notched at the lateral edges. row, and furnished rica.

\section{Hairs very strong.}

Africa. India.

Tail short.

America.

Tail short.

Small feet, with feathers almost to the toes. In both continents.

In the warm and humid parts of America. Several pairs lay in a common nest.

Tongue long, nar- Warm parts of Ame- 
a.' R. Proper.

Beak larger than the head. Fig. 147.

b. Pteroglossus, Illig. Aracari.

Beak less than the head, covered with a less solid horn. Fig. 148.

11. Pistracus, Lin.ParROTS.

Beak large, hard, solid, rounded entirely, encircled at its base by a membrane wherein the nostrils are pierced. (1).

Tongue thick, fleshy, and rounded.

Cheeks naked of fea- America.

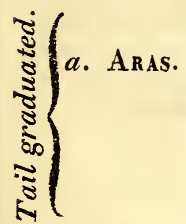

(b. Parrakeets.

a. Parrakeet Aras. Vaill. thers.
The torrid zone of both continents, but even every large island has its peculiar species, their wings not enabling them to cross any

extent of sea.
Circle around the eye naked.

f. Arrow-tailed ParRAKEETS.

The two middle penfeathers much longer than the others.

$\gamma$.

Tail enlarged towards the end. (2)

f. Parrakeets proPER, Vaill.

Tail almost equally graduated.

(1) This membrane and the form of their tongue, give them great facility in imitating the human voice. Their inferior larynx is very complicated, and furnished with three peculiar muscles on each side, which also contributes to the above faculty; their powerful jaws are put in action by a greater number of muscles than those of other birds. Their intestines are very long and they have no cœcum.

(2) The name of Loris has been given to those species the ground of whose plumage is red. 


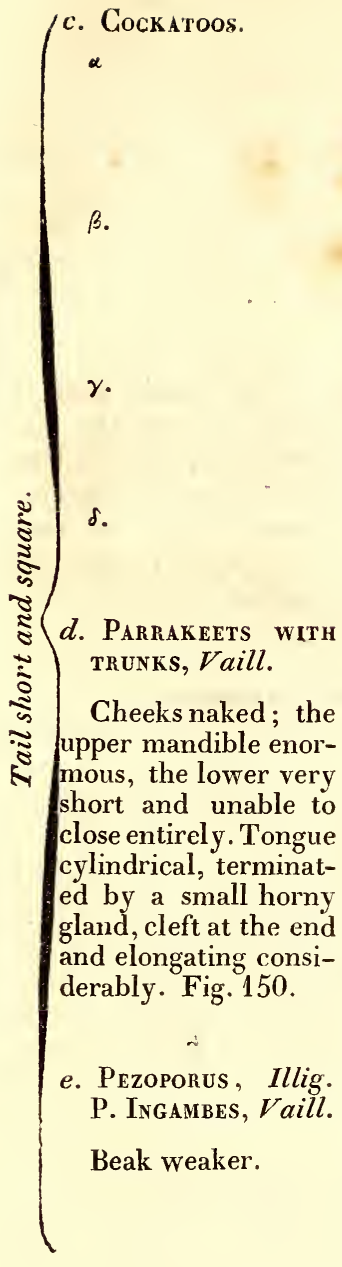

A crest of long narrow feathers, ranged in 2 lines and raised or lowered at will. Fig. 149.

Crest more simple, less moveable, and composed of large feathers of moderate length.

Pendent feathers, with fine barbs towards the end, instead of a crest.

No crest.
The more remote parts of India.

New-Holland : live on roots.
Crest of long and narrow feathers. Tarsi short and flat, rested on when walking. Fig. 150.
East-Indies.
Tarsi more elevated and nails straighter than in the other Parrakeets. Fig. 151 . 


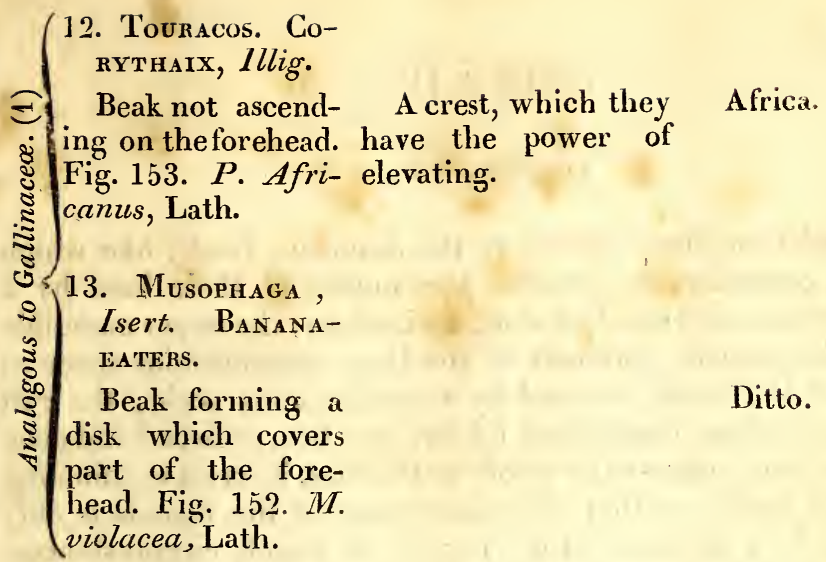

(1) They have the wings and tails of the Hoccos; their beak is short, the upper mandible swelled, and there is a short membrane between the front toes, but the exterior toe is often directed backwards; their nostrils are simply pierced in the horn of their beak, the edges of the mandible are dentated, and the sternum, at least that of the Touraco, has not the great notches ordinarily found in the Gallinacea. 


\section{ORDER IV.}

\section{Gallinacece,}

So named from their affinity to the domestic Cock, like which they have, generally, the anterior toes united at their base by a short membrane, and notched along their edges; the upper mandible vaulted; the nostrils, pierced in the large membranous space at the base of the beak, covered by a cartilaginous scale; the gait heavy; the sternum diminished by two notches, so broad and deep that they occupy almost the whole of its sides, its crest terminating obliquely in front, so that the sharp point of the furcula is only joined to it by a ligament (Fig. 167.) ; all which circumstances, by weakening their pectoral muscles considerably, render their flight difficult. Their tail has mostly 14 and sometimes even 18 pen-feathers, with the exception of the Alectors. Their inferior larynx is very simple, consequently none of them sing agreeably; they have a very wide crop and a very powerful gizzard. Excepting the Alectors, they lay and hatch their eggs on the ground, on heaps of straw or grass rudely scattered. Each male has generally several females, and does not interfere either with the nest or the care of the young, which are generally numerous, and, most frequently, able to run on coming out of the shell.

This very natural family, remarkable for having given us the greater part of our farm-yard fowls and much excellent game, can only be divided into genera by some unimportant characters taken from the appendages of the head.

\section{GALLINACE⿸厂}

\section{GENERA AND SUB-GENERA.}

1. Pavo, Lin. Peacocks.

The tectrices of the Brought from the tail, in the male, long- north of India by Alexer than the pen-fea- ander. thers, rise and spread.

a. P. Proper.

Egrets.

Spots like eyes in the extremities of the leathers. 
b. Polyplectrum, Tem.

Crests.

Spots of the tectrices of the tail(less elongated) double, and, like those of the scapularies, in the form of mirrors.

2. Meleagris, Linn. TurKIES.

The head and upper part of the neck covered with a nippledskin, bare of feathers; an appendage under the throat, and another on the forehead; a pencil of hairs hanging from the bottom of the neck of the adult male.

3. Alectors, Merrem. Curassows.

Tail with 12 penfeathers, stiff, broad, and rounded.

a. Crax, Lin. Hoccos. Mrroux.

Beak strong, the base covered with a skin, sometimes of a lively colour, in which the nostrils are pierced. Fig. 168. C. globicera.

b. Pauxi. Ourax, Cuv.

Beak shorter and stronger. Fig. 169.

c. Penelope, Merrem. Guans or Quans. JAcoos.

Beak thinner than Crax. Fig. 171. P. crestata.
The tectrices of the tail shorter and stiffer, but rise and spread like those of the Peacock.
A crest of round, long, narrow feathers, curling from the base.
Base of the beak, and the greater part of the head, covered with short velvet-like feathers.
Circle around the eye naked, as well as the lower part of the throat.
Tarsi of the males with two spurs.
From America.

No spurs.

America.

Tracheal artery descends, under the skin, behind theposterior edge of the sternum. 
d. Ortalida, Merrem.

Parrakas.

Scarcely any of the circle around the eye, or of the throat, naked.
Tracheal artery descends towards the abdomen.

e. Sasa. Hoazin, Buff.

Opisthocomus, Hof-

man. Crested Phea-

SANTS.

Beak of the Pauxis.

Crest of long, narrow, fine feathers.

No membrane between the base of the toes.

4. Satyrus. Napauls.

Males with a horn behind each eye. Fig. 173.

A large, loose, naked, extensible bag, un- both sexes. der the throat.

5. Phasianus. PheaSANTS.

Cheeks partly bare (or the circle around the eye) and with a red skin.

a. Gailus. Cocks. (1)

A fleshy and vertical crest; lower mandible with fleshy gills on each side.
14 pen-feathers to the tail, rising in 2 vertical planes.

b. Phasianus proper. (2)

Tail long, graduated; the pen-feathers forming 2 culminating planęs.

c. Grested Pheasants.

Egrets. Fig. 172. P. ignitus.

The lower edge of the naked skin of the cheeks spurs. projecting like gills.

(1) Amongst the wild species are, the G. Sonneratii, in which the feathers of the neck of the male expand towards the base in three successive disks of a horny matter (Fig. 170); the G. Bankiva, Tem., which has the crest dentated like the preceding, with long pendent feathers of a golden red on the neck; the Phas. varius with an entire crest and a small dew-lap, without lateral gills, under the throat.

(2) The $P$. pictus and $P$. Nycthemerus are from China; the P.Argus from the south of Asia. 


\section{(61)}

d. LOPHOPHORES, T'em .

Beak long, strong, curved, broad at the

Egrets.

Tail ordinary ; strong spurs.

base; the superior considerably exceeding the inferior mandible, which is hidden. Fig. 174, bis. L. Cuvieri, T.

e. Cruptonyx, Tem.

6. Numida, Lin. PiNTADO.

7. Tetra a, Lin. Grous.

a. Tetrao, Lath.

Toes naked. Fig. 178. T. Urogallus.

b. I_Agopus, Briss .

Toes covered.

c. Pterocles, Tem. GaNga. Attagen.

Toes naked.

d. Perdix, Briss. ParTRIDGES.

Toes naked.

$\alpha$. Francolines.

Beak longer and stronger. Fig. 181.

f. Perdix proper. 182.

Beak weaker. Fig.

Circle of the eye naked, but not red. Great toe very small. Fig. 177.

\section{Tarsi naked.}

Spurs stronger.

Spurs short or simple tubercles in the males,
Only the circle around the eye naked. Fig. 175. Great toe without a nail. Fig. 175.

Head naked, generally surmounted with a callous crest. Fig. 176. N. meleagris.

A naked band (generally red) in the place of the eye-brow.

Tarsi covered with feathers, and without spurs.

Generally become white in winter.

No spurs. Tail short, pendent.

From Africa.

Tail ordinary; nospurs.

Tail round or forked.

Tail round or square, Tail pointed.

Tail more developed. wanting in the females. 
e. Coturnix. Quails.

Less than the P.Pro- $\quad$ No spurs; band above per. Beak more slender: the eye whitish. Fig. 184.

\section{f. Colins. American Quails.}

Beak larger, shorter, more swelled. Fig. 183.

8. Tridactyles, Lacép. Hemipodius, Tem.

Beak compressed, swells a little under the lower mandible.

a. Turnix, Bonnat. OrTYGIS, Illig.

No great toe.
Toes separated to the base, and without the small membranes. Fig. 185.

b. Syr phaptes, Illig.

Wings extremelylong and pointed. Fig. 186. T.parodoxus.

9. Tinamus, Lath. CRYpTURus, Illig. Y YamBus, $A z z$.

Beak long, slim, blunt at the end, with a small furrow on each side; the nostrils pierced in the middle, and penetrating obliquely backwards. Fig. 187.

10. Columba, Linnoeus.

Pigeons.

Beak of Gallinacea.

No distinct mem-
Tarsi and toes feathered, the former short, the latter very short and united in a part of their length.

Neck slender, elongated,covered withfeathers with fine barbs and frizzed at the ends. spur, cannot touch the ground. America. from the type of the $\mathrm{Gal}$ linacea.

Scarcely any tail; wings short; the great toe, reduced to a small spur, cannot touch the

Tail shorter.

Emigrate across the Mediterranean.

Tail more expanded.

Polygamous.

In sandy countries. Anatomy not sufficiently known to class them with certainty.

Gait of quails.

Differ considerably branes between the feathers.

Tail with 12 penbases of the toes. 


\section{(65)}

a. Columbi - Gallines, Vaill.

Beak slim, flexible. Tarsi more elevated. Seek their food on the Fig. 179. C. caruncu- Fig. 179. ground. Live in troops. lata.

b. Doves.

Ditto.

Tarsi shorter.

c. Colombars, Vaill. VINAGo, Cuv.

Beak larger, solid, compressed at the sides. and well edged. Fig. 180. Fig. 180. C. Abyssinica.

Tarsi short; feet wide Frugivorous.

The great woods of the torrid zone of the old World. 


\section{(64) \\ ORDER V. \\ Gralla.}

The Gralla, Shore-Birds or Waders, take their name from their habits and the formation which gives rise to them. We recognise them by the nudity of the lower part of their thighs, and very frequently by the length of their tarsi, which circumstances enable them to enter the water to some depth without wetting their plumage, and to wade and fish in it by means of their neck and beak, both of which are of a length proportionate to their legs. Those with strong beaks live on fish or reptiles; those whose beaks are weaker, on worms and insects. A few partly content themselves with grains and herbage, and these only live far from the water. The exterior is most frequently united at its base to the middle toe, by means of a short membrane; sometimes there are two similar membranes, at others they are entirely wanting and the toes are separate; rarely, they are bordered all along or palmated to the end ; lastly, the great toe is wanting in several Genera : all which circumstances render their mode of life more or less aquatic. Almost all these Birds, if we except the Ostriches, have long wings and fly well. They extend their legs behind when they fly, contrary to other Birds, who fold them under thie belly.

\section{FAMILIES.}

1. Brevipennes.

Wings too short for Pectoral musclesve- No carina to the flight. ry slight, but those of sternum.

the legs and thighs enormous.

\section{Pressirostres.} 189 .

Beak moderate. Fig. Legs elevated; great toes too short to reach the ground, or none.

\section{Cultirostres.}

Beak large, long, strong, generally with sharp edges, and pointed. Fig. 199. 
4. Longirostres.

Beak slim, long, and weak. Fig. 208.

5. Macrodactyla.

Beak more or less Toesverylong,but no Body flattened from compressed, never so membranes between the narrowness of the slim or weak as in the the bases. Fig. 222. sternum. Wings moLongirostres. Fig. 222. derate or short; flight feeble.

6. Glareola, Gm. Pratincolies. Sea ParTRIDGES.

Beak short, conical, entirely arched, somewhat cleft. Fig. 224.

Tarsi plated, exte-

Wings exceedingly rior toes a little pal- long and pointed. mated, great toe touching the ground.

The description of the Family is that of the only Genus.

\section{Phenicopterius, Lin.}

\section{Flamingos.}

Neck as slim and as Legsexcessivelylong, long as their legs; head 3 front toes palmated small; the inferior man- to the end, the great dible oval, bent longi- toe extremely short. tudinally in a demi-cylindrical canal; the superior mandible oblong and flat, bent transversely in the middle to join the other exactly. Fig. 220.

The five transversal plates which edge their mandibles, and the fleshy thickness of their tongue, approximate them to the Anas.

In all parts of the world, from lat. $40^{\circ}$ to $45^{\circ}$.

The description of the Family is that of the only Gen us.

\section{FAMILY I. BREVIPENNES.}

\section{GENERA AND GUB-GENERA.}

1. Strruthio, Lin. Os-

TR ' CHES.

Beak depressed hori-

Wings covered with zontally, of moderate loose flexible feathers,
length, blunt at the and long enough to acend; tongue short, and celerate their course. rounded like a crescent; eyelids with hairs.
An enormous crop, and a considerable ven. tricle between the crop and the gizzard. Coecum long, and a vast cloaca wherein the urine accumulates. 
a.

From 6 to 8 feet high. 2 toes; and the exte- Eggs nearly 3lbs. rior, one half shorter than weight.

the other, without a nail. Africa.

b. RHEA, Lath.

From 3 to 4 feet high. 3 toes, all with nails. America.

2. Casuarius, Briss. $\mathrm{C}_{\mathrm{A}}$ soars. Cassowaries.

Wings shorter, and 3 toes, all with nails; useless in their course. the barbs of their feathers resembling horsehair.

a.

Beak compressed la- Headsurmounted with Nail of the inner toe terally. a bony prominence co- much the largest. vered with a horny sub- Indian Archipelago. stance.

$b$.

Beak depressed. No casque. (1) Nails equal. •

\section{FAMILY II. PRESSIROSTRES.}

\section{GENERA AND SUB-GENERA.}

1. Otis, Lin. Bustards.

Beak moderate, thesu- Verysmall webs be- Tarsi reticulated, perior mandible slightly tween the bases of the wings short, feet and arched and vaulted. Fig. toes. neck long; fly but lit193. Otis tarda. tle.

2. Charadrius, Linn.

\section{Plovers.}

Beak moderate, compressed, enlarged at the end. Fig. 223,
No great toe.

(1) The Genus Didus (Dodo) of Latham, comprehends the $D$. Ineptus, a species which has disappeared, but a head of which, much injured during a lapse of 150 years, is preserved in the Ashmolean Museum, at Oxford (Fig. 188), and a foot in the British Museum (Fig. 188); the D. Solitarius, which rests on the single testimony of Leguat, who has disfigured even the Lamantin, Hippopotamus and other well-known animals; the $D$. Nazarenus, seen by Gauche only, who, stating that it has 3 toes, considers it to be the same as the $D$. Ineptus, which has 4 . 
a. OEdicnemus, Cuv.

End of the beak enlarged above and below. Fig. 190.
Nasal canal extending only one half the length of the beak.
Feet reticulated. Dry, stony soils.

\section{b. Charadrius proper.}

End of the beak en- Nasal canal extending larged above only. Fig. two-thirds the length of 189. the beak.

3. 'Tringa, Lin.

Beak of the Plovers. Great toe so small as not to touch the ground.

a. Squatarola, Cuv.

SANDPIPERS.

Beak enlarged underneath.

Great toe scarcely perceptible; nasal canal

Feet reticulated. short. b. TRINGA PROPER. LAP-
WINGS.

Great toe more evident; nasal canal twothirds the length of the beak.

Tarsi partly plated.

Tarsi reticulated; only 3 toes.

Nasal canal deep, half the length of the beak, with the nostrils pierced in the middle like a small crack.

4. Hematopus, Lin. SeApirs, OYster-Catchers.

Beak rather longer, straight, pointed, compressed in a wedge, strong enough to open bivalve shells. Fig. 194. Hamatopus ostrolegus.

5. Cunsorius, Lac. Tachyoromus, Illig.

Beak more slim, equally conical, arched, No great toe. Legselevated; 3 toes. without furrow, and moderately cleft. Fig. 191. 
6. Cariama, Briss. MiCROdACTYLU, Geoff.

Dicholophus, Illig.

Beak large, more crook'd, cleft to below the eye. Fig. 196. C. de Margrave.

Great toe not reach- Legs plated, very ing the ground. long; toes extremely short, a little palmated at the base.

\section{FAMILY III. CULTIROSTRES.}

\section{GENERA AND SUB-GENERA.}

1. Grus, Cuv. Cranes.

Beak straight, but lit- Legsplated; the great tle cleft ; the membra- toe scarcely reaching nous nasal canal, broad the ground.

and concave, occupies half the length.

a. Psophia, Lin. Agamis.

Trumpeters.

Beak short.

Head and neck covered with down only, circle around the eye naked.
Granivorous and frugivorous.

From America.

b. Numidice. Numidiax Cranes.

Beak shorter. Fig. 199. Ardea Pavonia, $\mathrm{L}$.

Africa.

c. Grus proper.

Beak as long and longer than the head.

$\int$ More carnivorous; beak stronger; toes larger.

2. Cancroma, Lin. BoatBills. Savacous.

Beak resembling Nostrils pierced to- 4 toes, long, and alspoons joined by their wards the base of the most without memconcave sides; the su- beak, and prolonged in branes. Piscivorous. perior mandible with a two parallel furrows sharp tooth on each side towards the point. of the point. Fig. 192 .

C. Cochlearia. 
3. Andea, Cuv. Henons.

Beak cleft to below the eyes, which are in a naked skin extend̉ing to the beak.

Nasal canal prolong- Legs plated; toes ed in a furrow very rather long, exterior nearly to the point of webs evident. Their the beak. dung burns the trees.

a. Ardea proper.

Neck very slim, with long pendant feathers at the base. Fig. 195.

b. Egrets.

The feathers of the lower part of the back singularly long and fine.

c. Butor. Bitterns.

The feathers of the neck loose and far apart.

d. Bithoreau. NightHERONS.

Stiff slender feathers in the occiput of the adult male.

IS Beak longer, smoother; webs, almost equal aind rather thick, between the bases of the toes.

4. Ciconia, Cuv.STORKs.

Beak large, moderately cleft; tongue ex- row; nostrils pierced tremely short. Fig. 202. towards the base of the with their mandibles. beak.

5. Mycteria, Lin. $\mathbf{J}_{A-}$ BIRU.

Beak slightly curved Ditto. - Legs reticulated. in the upper part. Fig. 203.

6. Scopus, Briss. Umbres.

Beak compressed, the Nostrils prolonged culminating edge sharp in parallel furrows to and enlarged towards the end of the beak. the base; the end a little crook'd. Fig. 204. 
7. Hians, Lacép. Anasromus, Illig. OpeNBEAKS.

Mandibles join only at their base and points, having a void interval in the middle of their edges, appearing to be partly the effect of detrition. Fig. 205.

\section{Tantalus, Lin.}

Beak as Ciconia, but the back rounded, the point curved, and slightly notched on each side. Fig. 206.

\section{Platalea, Lin. \\ Spoon-BILLs.}

Beak long, flat, broad, like a spatula; tongue small. Fig. 214.

\author{
Nostrils as Ciconia. Part of their head \\ bare.
}$$
\text { * }
$$

Nostrils oval, and pierced near the origin of slight furrows proceeding from the base to the end of the beak.

\section{Legs reticulated.}

1. Scolopax.

a. IbIs, Cuv. (1)

Beak arched, weaker than that of the Tantalus, without notch at the point, almost square at the base. Fig. 208. S. Rubra.

b. Numenius, Cuv. CresCENT-BEAKs. GurLews.

Beak arched, round in the whole length, weaker, the upper end passing the lower. Fig. 213.
Nostrils pierced towards the back of the base, and prolonged in a furrow to the end. . base; great toe long enough to rest on the ground.

(1) M. Cuvier (Recherches sur les Ossemens Fossiles, t. 1. p.) shews the Ibis sacer of the Egyptians to be the Numenius Ibis or Tantalus OEthiopicus of Latham, Fig. 209; Fig. 210 was drawn from the head of a mummy found at Thebes, and now in the Gallery of the Museum at Paris; Fig. 207 is from one of the temples in Upper Egypt. 
c. Pheopus, Cuv. WhimBRELS.

Beak depressed to- Furrow of the nostrils wards the end. Fig. 216. almost the whole length of the beak.

$d$. Falcinellus, Cuv. Pyg* MY-CURLEWS.

Ditto.

Ditto.

Nagreat toe.

e. SCOlOPAX PROPER.

Woodcocks. SNIPES.

Beak straight, the end of the upper mandible (enlarging to surpass the lower) soft, very sensible, and drying into a point after death. Fig. 201.

Ditto, with a simple furrow on the lower
Head compressed; eye large and very far back.

\section{$f$. Rynchoea, Cuv.}

Mandibles ncarly equal, arched slightly at the ends. Fig. 197.

Ditto, but no furrow on the lower mandible. the ends.

\section{g. Lrmosa, Bechst. Gov- wITs.}

Beak straight, or slightly arched towards the upper part; the end depressed and blunt. Fig.

Ditto.

Form more slender and. legs longer than in the Scolopax.

Spots, like eyes, on the pen-feathers of the wings and tail.

Africa. India. 200.

\section{h. Calidris, Cuv. Sand-} PIPERS. KNots.

Beak depressed at the end, not longer than the head.

i. Pelidna, Cuv Purres.

Stints. Sea-larks.

Beak of Calidris, but a little longer than the

Ditto.

Toes slightly bordered, without webs at their base; great toe scarcely long enough to reach the ground (Fig. 221), gait and form heavy.

Ditto.

Toes without borders or webs. 
k. Machetes, Cuv. Rufrs and Reeves. ComBATANTS.

Beak and gait of $\mathrm{Ca}$ lidris.

Web between their exterior toes as large as in the Limosa.

l. Arenaria, Bechst. CauIdris, Illig. CurWILLETS.

Ditto.

$m$. Phalaropus, Briss.

Beak flatter than in the Calidris, the fur- large membranes, like rows the same. Fig. 198. the Fulica.

$n$. Strepsilas, Ill. TurnSTONES. SEA-DOTTRELS.

Beak conical, pointed, not depressed; nasal canal half the length. Fig. 217.

o. Totanus, Cuv. Snipes. SAN D-PIPERS. HorseMEN.

Beak slim, round, pointed, furrow of the nostrils half the length; the upper mandible a little arched towards the end.Fig.219.S. glottis.

p. Lohipes, Cuv.

Ditto.

q. Himantopus, Briss. Macrotarsus, Lac. Long - Legged Plovers.

Beak of Totanus, but more pointed.

2. Recurvirostra, Lin. Avosets.

Beak long, slim, pointed, smooth, elastic, with a strong curve upwarls. ground.

Fig. 215.

No great toe.

Toes edged with very

Great toe scarcely touches the ground.

\author{
.
}




\title{
FAMILY V. MACRODACTYLA.
}

\author{
GENERA AND SUB-GENERA.
}

$\int$ Wings armed with spurs.

1. JACANA, Briss. P $\mathrm{PAR}_{\mathrm{AT}}$ $\mathrm{R} \Lambda, L \imath n$.

Beak moderately long, slightly enlarged at the end. Fig. 222.

One spur to each Marshes of warm wing. Four toes, very climates.

long, separated to the roots; the nails, especially that of the great toe, very long and pointed. Fig. 222.

2. Palamedea, Lin. $\mathbf{K}_{\mathbf{A}-}$ michr. Screamers.

Beak little cleft and compressed, not enlarg- each wing. Toes withed, and the superior ont webs, nails strong, mandible slightly arch- that of the great toe ed. Fig. 218. P. cor- straight. Fig. 218.

nuta.

\section{SS Wings unarmed.}

3. Rallus, Lin. Ralls.

Beak without frontal plate.

a. Rallus, Bechst.

Beak longer. Fig. 225 .

b. Crex, Bechst.

Beak shorter. Fig. 226.

4. Fuljca, Lin.

Beak with a frontal plate covering the forehead. 
a. Gallinula, Briss and Lath. WATER-FOWLS. Fig. 211.

Border of the toes nar-

b. Porphyro, Briss. Sul-

TANS.

Beak deeper in pro- Border of the toes portion to its length; scarcely evident. frontal plate considerable.

c. Fulica proper, Briss.

Coots.

Beak short.

Border of the toes wide and festooned. 


\section{ORDER VI.}

\section{Palmipedes,}

Are strongly characterised by their feet formed for swimming, that is, set in the hinder part of their body (Fig. I), with very short and compressed tarsi, and palmated between the toes.

Their close, glossy plumage, imbued with an oily juice and furnished with a thick down next the skin, protects them from the water on which they live. They are the only Birds in which the length of the neck exceeds (sometimes considerably) that of the feet (Fig. 1), having frequently to fish in the depth whilst they swim on the surface of the water. Their sternum is very long, protects the greatest part of their viscera, and has but one notch on each side, or an oval hole furnished with membranes. Their gizzard is generally muscular, their cœecums long, and the inferior larynx simple, with the exception of one Family, in which it is swelled into cartilaginous capsules.

\section{FAMILIES.}

1. Brachypteres.

Legs further back Wings exceedingly Plumage very close, than any of the follow- short; fly very ill, or and offering a smooth ing, making their walk not at all.

very painful, and obliging them to preserve a vertical position. Fig. and shining surface; swim under water, using their wings as fins : a peculiar muscle on each side of the lower larynx : coecum moderate.

\section{Longipennes.}

Beak, without notches, crook'd at the end, flight extensive. Great or simply pointed. toe free or none.

Only one muscle on each side of the inferior larynx: coecums short.

3. Totipnlmes.

Greattoeunitedwith Feet short; perch the others in a single on trees. membrane. 
4. Lamei.lirostres.

Beak thick, covered with a soft skin rather

Wings moderate. than a true horn; the edges with plates or small teeth. Fig. 251.
Tracheal artery of the male generally expanded near the bifurcation into capsules of different forms : cœcum long.

\section{FAMILY I. BRACHYPTERES.}

\section{GENERA AND SUB-GENERA.}

1. Colymbus, Lin.

Beak smooth, straight, compressed, pointed; nostrils linear.

a. Podiceps, Lath. CoLYMBUs, Briss. and Illîger.

'Toes enlarged (like those of the Fulice) instead of true webs, those in front united, at the base only, by membranes. Fig. 227, bis.

b. Colym. Proper, Lath. Mergus, Briss. EudyTES, Illig. Divers.

Feet of Palmipedes in general, that is, the front toes united (to the ends) by membranes, and terminated by pointed nails.

c. URIA, Briss, and Illig. GuILlemots.

Beak with feathers to the nostrils, and notched at the point, which is a little arched. Fig. 230.

No great toe.

Middle nail flattened; Plumage, of a metallic tarsi compressed.

Northern Birds, visiting our latitudes only in winter.

Wings still shorter than in the Colymbus.

In steep rocks.

\section{d. Cephus. Greenland- PIGEONS.}

Beak shorter, with its back more arched,with- rather deeply notched. out notch; symphysis of the lower mandible extremely short. Fig. 228.

Merrbranes of the toes Wings stronger. 
2. Alca, Lin.

Beak much compressed, elevated vertically, mated; no great toe.

the back sharp, generally furrowed transversely.

a. Fratercula, Briss. Mormon. Illig. Aurs.

Beak,shorterthan the head, as deepand deeper near the edge. at the base than long. Fig. 231 .

\section{b. Aich, Cuv. Penguins.}

Beak more elongated, Feathers as far as the like the blade of a knife. nostrils.

Fig. 233.

\section{Aptenodytes, Forst.}

Feet, more back ward than in any other Birds, rected inwards; the vestiges of feathers,
only afford support by three anterior toes like scales. resting on the tarsus, united by an entire which is enlarged like membrane.

the sole of the foot of a quadruped; its interior presenting three bones, soldered together at the extremities. Fig. 229.

\section{a. Aptenodytes, Cuv. PA- tagonian Pinguins.}

Beak slim, long, pointed; the superior mandible a little arched towards the end. Fig. 236.

\section{b. Catarrhactes, Briss.}

Beak strong, little compressed, pointed, the back rounded, the point a little arched. Fig. 232.
Northern seas.

Small wings, supporting them for a moment.

Live on the sea, nest in rocks.

Wings too small to sustain them, therefore do not fly at all.
Feathers covering one Furrow from the nos= third the length of the trils to the end of the beak or to the nostrils. beak.
Furrow from the nos" trils terminating obliquely at the edge of the beak. 


\section{c. Spheniscus, Briss.}

Beak compressed, straight, irregularly furrowed at the base, the end of the upper mandible crook'd, that of the inferior truncated. Fig. 234.

\section{FAMILY II. LONGIPENNES.}

\section{GENERA AND SUB-GENERA.}

1. Procellaria, Lin.

Beak crook'd at the end, the extremity having the appearance of a piece articulated to the

Nostrils in the middle, not covered.

rest.

a. P. Proper. Petrels.

Inferior mandible truncated. Fig. 240.

b. Puffinus, Briss. PufFINS.

End of the inferior mandible curves downwards with that of the upper; beak more elongated. Fig. 235.

c. Pelecanoides, Lacép.

Halodroma, Illig.

Ditto.

Nostrils united in a tube on the back of the instead of a great superior mandible. toe. (1)

A nail on the heel,

\section{d. Prons, Lacép.PACHY P- TILA, Illig.}

Beak enlarged at the base, the edges furnished with plates like the dnas. Fig. 259, bis.
Nostrils not opening by a common orifice, but by two distinct holes.
Throat dilatable; no great toe.

Ditto.

(1) They remain a longer time at sea than any of the other Palmipedes, and are often obliged, when a storm approaches, to fly to vessels for refuge : they make their nests in the holes of rocks and shoot an oily juice, of which their stomach appears to be always full, at those who attack them. 
2. Diomedea, Lin. AlBATRosses.

Beak large, strong, Nostrils, like rolls, No great toe or nail sharp, with distinct su- short, on the sides of in place of it. The most tures, and terminated the beak. massive of all the Palby a crook seemingly articulated. Fig. 257. mipedes.

A ustral seas.

\section{Larus, Lin.}

Beak compressed, eNostrils, towards the Great toe short. (1) longated, pointed; the middle, long, narrow, superior mandible arch- open.

ed towards the end; the inferior forming a projecting angle underneath.

a. Goelands. Gulls.

Larger than Ducks. Fig. 2:37.

6. Mauves. Sea-mews.

Less than Ducks.

c. Stercoraikes, Briss. LabBes, Buff. LESTRIS, Illig.

Nostrils membranous, and the orifices nearer the point and edge of the beak. Fig. 242.

4. Sterna, Lin. SeaSW ALLOWS.

Beak pointed, compressed, straight, without curve or projection; nostrils towards the

Wings extremely Membranes, uniting base, oblong and pierced interruptedly. Fig. 238.

(1) They feed on all kinds of fish, the flesh of dead bodies, etc. : when they Aly inland it is a sign of bad weather.

(2) They pursue the small Sea Mews with inveteracy, to deprive them of their fond, and, as some say, to devour their dung. 
a. Noddies.

A slight projection under the beak.

b. Tenns.

5. Rhynchops, Lin. CutWaters. Skivimers.

Theinferior mandible of the beak much longer than the other, and hoth flattened in simple plates. Fig. 243. R. Nigra.
Tail, not forked, almost as long as the wings.

T'ail forked.
Wings long; tail Feet small. Subsist forked. on what they snatch from the surface of the water with their lower mandible during their flight.

\section{FAMILY III. TOTIPALMES.}

\section{GENERA AND SUB-GENERA.}

1. Pelecanus, Lin.

Skin of the throat more or less dilatable- of the beak, bare of Tongue very small. feathers; nostrils like cracks, with the openings scarcely evident.

a. Onogrotalus, Briss. Peleganus, Illig. PELIGANS.

Beak extremely long, straight, broad, and flattened horizontally, terminated by a crook. Fig. 246.

The inferior mandible sustaining a naked membrane, dilatable into a large bag; 2 furrows, the length of the beak, hiding the nostrils.

b. Phalacrocorax, Briss.

Carbo, Meyer. Hanueus, Illig. ConvoRANTS.

Beak elongated, compressed, the end of the upper mandible crook'd, that of the lower truncated. Fig. 245.
Tongue very small, skin of the throat less di- second toe notched like latable, the nostrils like a saw. a fine line imperceptibly pierced.
Circle of the eyes marked like the throat; tail round.

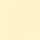


c. Frigate-bihds. Mer

OF WAR Birds.

Both mandibles curved at the end. Fig. 244.

Tail forked, the feet short, membranes deeply notched. (1)

d. Sula, Briss. Dysporus, Illig. Boobres. Soland GEESE.

Beak straight, slightly compressed, pointed, line nearly to the point; the point a little arched the throat and the circles (fig. 1), the edges den- of the eyes naked, the tated within like a saw. former little dilatable.

Envergure excessive.

Nail of the middle toe notched like a saw ; wings less than in the Frigate Birds. Tail somewhat wedge-shaped.

2. Peotus, Lin. DARTzirs. Anhinga.

Beak straight, slim, pointed, the edges denNeck long.

Feet like the Cortated; head small. Fig. vorants.

249.

3. Phaton, Lin. TropicBIRDS. StraW-Tails.

Beak straight, pointed, dentated, moderately strong. Fig. 241.

Two narrow and Feet short, wings verylong feathers, like long. Rarely quit the straws, in the tail. Torrid Zone.

\section{FAMILY IV. LAMELLIROSTRES.}

\section{GENERA AND SUB-GENERA.}

1. Axss, Lin.

\section{a. Cygnus Meyer.}

Beak as broad before Nostrils nearly in the as behind, deeper than niddle of the length of broad at its base; neck the beak.

very long. Fig. 251 .

b. Anser, Briss. Gense.

Beak moderate or short, narrower before than behind, deeper than broad at its base.

(1) Their powerful wings enable them to fly immense distances from land, principally between the tropics : they dart on the Flying-Fish and strike the Boobies to make them disgorge their prey. 
๙. Axser phoper.

Beak as long as the head; the ends of the plates at the edges having the appearance of pointed teeth.

R. Barmacles. Chatis. Brand-GeEse.

Beak shorter, slighter ; the ends of the plates not visible at the edges. (1)

c. Anas proper. Ducks.

Beak not so deep as broad at its base, and as broad (or broader) at the extremity as towards the head.

$\oint$ Great toe bordered by a membrane.

$\alpha$. Macreuses. Scoters.

Beak broad and swelled. Fig. 248.

\section{f. Garrots.}

Beak shorter and narrower before. Fig. 250.

\section{$\gamma$. Eiders.}

Beak narrower before, but longer than in the Garrots and ascending higher on the forehead, forming an angle with the feathers. Fig. 256.

\section{$\delta$. Millouins.}

Beak broad and flat.

Nostrils nearer the back and base of the beak.
Legs shorter, place more backwards.

Fig. 239.

SS Great toe not bordered.

Trachea terminate in enlargements, forming a capsule, partly membranous, to the left, supported by bony ramifications.

$\varepsilon$. Shovelebs.

Upper mandible bent into a demi-cylinder, enlarged at the end ; the plates solong and thin as to resemble hairs. Fig. 254.

(1) The A. Erythropus, Gm., celebrated by the fable of its growing on the trees like a fruit (See Grey's notes on Hudibras), visits us in winter. 


\section{T. TADOANBS.}

Beak much flattened towards the end, raised in a projecting swell at the base. Fig. 255.

d. Mergus, Lin. MergaNSERS. HARLES.

Beak more slim, more cylindrical, each man- mandible crook'd. dible armed along its edges with little pointed teeth(like those of a saw) directedbackwards.Fig.

The end of the upper

258. M. serrator.

The enlargement of the inferior larynx enormous and partly membranous, in the males. Live on ponds and lakes.

The 4 additional species of Accipitres, figured to fill up the last plate, are, Cathartes vulturinus, Tem., from New California, Fig. 260 ; Vultur monachus, Lath., or Chincou, from India, Fig. 261; Strix leucotis, Tem., from Senegal, Fig. $262 ; S$. ascalaphus, Savig., from Egypt, Fig. 263.

Those who possess the 'Analysis of the Natural Classifications of Mammalia,' will insert the following new Sub-Genus of Bats, immediately after that of Phyllostoma, p. 29.

6. Grossoph a a, Geoff.

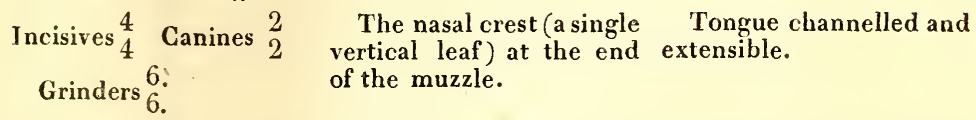

Sp. Vesp. soricinus, Pall. G. amplexicanda. G. caudifer (figured in the T'able to face p.12). G. ecaudata. The three latter were found in the neighbourhood of Rio Janeiro, by M. de Lalande..........The skull, brought by the same traveller, is that of " a Makoca, a people beyond the Caffres: "in order to preserve the facial angle precisely, it was drawn by the Camera lucida. 



\section{AUTHORS CITED.}

Azz...... Azzara......Voyages dans l'Amérique Méridionale de 1781 jusqu'en 1801. Paris 1809, t. 3. 4.

Bechst... Bechstein. .. Histoire Nat. usuelle de l'Allemagne (en Allemand). Leipz. 1801-9. 4 vol. $8^{\circ}$.

Bonel.... Bonelli...... Catalogue des Oiseaux du Piémont, $4^{\circ} .1811$.

Bonnat. . Bonnaterre. . Encyclopédie Mèthodique.

Briss..... Brisson ..... Ornithologie, 6 vol. in-4o. Paris, 1770.

Buff.....Buffon......Histoire naturelle, générale et particulière. Paris 1749-89, 36 in $-4^{\circ}$.

9 D'oiseaux.

Les planches enluminées des oiseaux, 1008, sans ordre.

Daud..... Daudin....Traité élémentaire et complet d'Ornithologie. 2 vol. 40. Paris, 1800.

Dum. .... Dumeril ....Traité élément. d'Hist. Nat. Paris, 2 vol. 8º 1807.

Edw...... Edwards.... Natural History of Rare Birds. 4 vol. $4 \circ$.

Forst..... Forster......Z Zoologice indica rarioris spicilegium. in $4^{\circ}$. Londoni, 1790.

- . . . . . . Enchiridion Historic naturali inserviens, in-8 ${ }^{\circ}$. Halle, 1788.

Fr. ...... Frisch...... Représentation de quelques oiseaux d'Allemagne et de quelques étrangers (en Allemand). 2 vol. fol. Berl.1739-63.

Geoff..... Geoffroy St.-Hilaire. Mím. dans le Mazas. Encyc. Ann. du Mus.-Ouvr. sur l'Egypte.

Gmel..... Gmelin.....13th Ed. Systema Naturce. Leipsig. 1788. 7 vol.

Hofm.... . Hofmanseck. Mémoires sur des animaux du Brésil et du Portugal.

Humb.....Humboldt. . Observations de Zoologie et d'Anatomie comparée. Paris. 4 . 1811.

Illig... . . . Illiger. . . . . Prodromus systematis Mammalium et Avium. 8०. Berlin, 1811. Jacq.... Jacquin .... Des matériaux pour l'Histoire des Oiseaux (en Allemand). 1 vol. in-4o. Vienne, 1784.

Kle....... Klein......Historice avium prodromus. Dantzick, 1750.

-........... . Stemmata avium. Dantzick, 1759.

Lacep..... Lacepéde.

Lath...... Latham..... General Synopsis of Birds. 3 vol. in-4 ${ }^{\circ}$. and 2 suppl. London, 1782.

- ....._- ... Index Ornithologicus. 2 vol. 4. London, 1790.

Linn. .... Linnæus..... Systema Naturce, 1757-1766.

Margr....George Margrav de Leibstad. Historia rerum natularium Brasilia, libri 8. in-fol. Leyde et Amsterd. 1648.

Mer......Merrem.....Avium rariorum et minus cognitarum icones et descr. $4^{\circ}$, Leipz. 1786. 
Meyer et Wolf......T'Tasehenbuch, etc. (Almanaeh des Oiseallx d'Allemagne). 2 vol. in-8 $8^{\circ}$. Franef, 1810.

Moehr. ....Moehring...Avium Genera. 8०. A urich, 1752.

Mïll...... Müller......Zoologica Daniea, fol. Copenh. 1788-9.

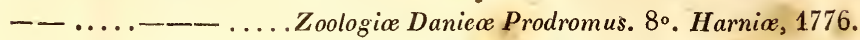

Pal.......Pallas ..... Spieilegia Zoologica. Berl.1767-80.

_...... . ..... Voyage dans plusieurs provinces de l'Empire de Russie. 8 volin-8 . et un atlas. Paris.

Pen...... Pennant .... British Zoology, in-fol. 1. vol.

- ........... Do. do. 8०. 4 vol.

- ..... -...Aretie do. 4 . 2 vol.

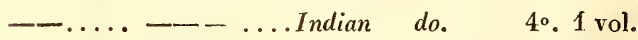

Rai..... Rai........ Synopsis methodica avium et piseium. in-8 ${ }^{\circ}$. London, 1713.

Sav...... Savigny......Mémoircs sür les oiseaux de l'Egypte.

Sh.......Shaw.......Naturalist's Misecllany. London, 1789.

- ........... General Zoology. do. 1800.

- ..... - .....Zoology of New-Holland. do. 1794.

Son.......Sonnerat....Voyage à la Nouvelle Guinèe. 1 vol. 4. Paris, 1776.

-...... _- ... Voyage aux Indes Orientales et a la Chine. 2 vol. 4०. Paris, 1782.

Temm....Temmink... Histoire naturclle générale des Pigeons et des Gallinaces. Amster. et Paris, 1803-15.

.Manuel d'Ornithologie, ou Tableau systématique des Oiseaux qui se trouvent en Europe. $8^{\circ}$. Amster. et Paris, 1815.

Vaill.....Le Vaillant..Hist. nat. des Oiseaux d'A frique. 5 vol. in-4. Paris, 1799.

- ...._-_.. Do. des Pcrroquets. 2 vol. in-4. Paris, 1801.

Do. des Oiseaux de Paradis, Rolliers, Toucans et Barbus. 2 vol. in-fol. Paris, 1806.

Do. des Promerops et des Guêpicrs. Paris, 1807.

Vieill..... Vieillot. ....Hist. nat. des plus beaux Oiseaux chanteurs de la zone torride. in-fol. Paris, 1805.

Hist. nat. des Oiseaux de l'Amérique septcntrionale. 2 vol. in-fol. Paris, 1807.

Analyse d'une nouvelle Ornithologie élémentaire. in-8०. Paris, 1816.

White......Voyage to Ncw South Wales. 1 vol. in.4*. London, 1790. 


\section{INDEX TO THE ORNITHOLOGY.}

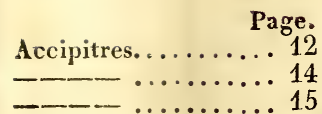

Agamis..............6 68

Aigle Autour........ 24

- Pêcheur....... 24

Alauda .............. 42

Albatross ............ 79

Alca ............. 77

Alcedo ........... 50

Alectors. ........... 59

Ampelis........... 37

Anas............ 81

- Proper.......... 82

Anastomus. ......... 70

Anhinga .......... 81

Anis ............. 54

Anser.............. 81

Proper ....... 82

Anthus ........... 41

Aptenodytes ......... 77

Apus.............. 41

Aquila............. 21

(

Ara.............. 55

Aracari............ 55

Ardea. ..........6 69

_- Proper......... 69

Arenaria........... 72

Astur.............. 21

- $\ldots . . . . . . . .26$

Proper........ 26

Attagen ............6 61

Auks............. 77

Autours ............ 21

$\Lambda$ rosets........... 72

Balbusards......... 25

Bald-heads......... 37

Banana-eaters...... 57

Barbacous........ 53

Barbets............ 53

Barbicans.......... 54

Barita............ 35

Barnacles .......... 82

Becardes.......... 35

Bee-eaters ......... 50

Beef-eaters.......... 45
Bethylus........... Page.

Bithoreau..........6 69

Bitterns .......... 69

Blackbirds.......... 38

Boat-bills.........6 68

Bombycivora........ 37

Boobies........... 81

Bouvreuils ......... 35

Brachypteres........ 75

- ........ 76

Brevipennes......... 04

- - ......6 65

Bubo............... 28

Bucco............... 53

- - Proper ........ 54

Buceros ........... 50

Budytes........... 41

Bullfinches.......... 44

Buntings........... 43

Buphaga ........... 45

Bustards........... 66

Buteo............. 21

Butor .............6 69

Buzzards............ 21

Calidris........... 71

- _............ 72

Callæas............. 45

Canchroma ........6.68

Caprimulgus ........ 42

Caracara............ 25

Carbo............... 80

Carduelis .......... 44

Cariama...........6 68

Caryocatactes ........ 47

Casoars. .........6 66

Casowaries.........66 66

Cassicans ........... 35

- $\ldots \ldots \ldots \ldots .45$

Cassicus.......... 45

- - Proper ...... 45

Casuarius.... ....... 66

Catarrhactes ....... 47

Caterpillar-catchers. . 37

Cathartes........... 18

Ceblepyrus............ 37

Centropus......... 53

Cephas............. 71
Cephalopterus....... Page. 37

Certhia........... 48

- - Proper......... 48

Ceyx............. 50

Chaffinches.......... 44

Charadrius......... 66

-_ Proper.... 67

Chardonnerets...... 44

Chatterers ......... 37

Choucaris............ 35

Ciconia.............6 69

Cinclus............ 39

Cinnyris............ 49

Circus............. 21

Clakis........... 82

Climbers......... 51

Cockatoos............ 56

Cocks ..............6 60

Cocothraustes ....... 44

Colaris ......... 47

Colibris...........449

Colies............ 45

Colins............ 62

Colius.............. 45

Columba .......... 62

Columbars.........6 63

Columbi Gallines.... 63

Colymbus......... 76

$$
\text { Proper....776 }
$$

Combatants........77 72

Conirostres......... 34

- - - .......42

Coots............ 74

Coracias.......... 47

___ Proper ..... 47

Corvorants........ 46

Corvus .......... 46

.._- Proper...... 46

Corythaix......... 57

Corythus ......... 44

Cotinga,......... 37

___ Proper ...... 37

Coturnix.........6 62

Couas........... 52

Coucals........... 53

Courols........... 53

Granes ...........68 68

Numidian... 68 


\section{INDEX TO THE ORNITHOLOGY.}

Page.

Crax............ 59

Creepers.......... 48

Crescent-beaks ......71

Crex .............77 73

Cross-bills........44 44

Crotophoga ........ 54

Cryptonyx ........66 61

Crypturus.........66 62

Cuckows..........52

_—— Proper .... 52

Cuculus ......... 52

Cultirostres .........64 64

Curassows ........ 59

Curlews ..........71

- Pygmy ......7 71

Curruca .........4 40

Cursorius ........66 67

Curucius. ........ 54

Curwillets ........ 72

Cut-waters........8 80

Gygnus........... 81

Cymindis.........24

Cypselus..........4 41

Dacnis ........... 46

Drdalion .......... 21

Darters... ....... 81

Dendrocolaptes..... 48

Dentirostres........ 33

- - - - ....... 34

Dicæum.......... 48

Dicolophus......... 68

Diurnæ........... 15

- - ......... 16

Divers............. 76

Dodo............. 66

Doves........... 63

Drongo........... 38

Ducks ........... 82

Dysporus ......... 81

Eagles.......... 21

- - Proper....... 24

- Short - winged fishing....... 24

Echassiers ......... 13

Edolius............ 38

Egrets. . . . . . . . . 69

Eiders............ 82

Elanus........... 26

Emberiza ......... 43

Epimachus......... 48

Eudytes..........76

Eulabes ..........44 47

Falcinelles........ 71

Falco ........... 14

- $\ldots \ldots \ldots \ldots . .16$
Falcon ........... 16

Ficedula......... 40

Fissirostres......... 33

- - ........ 41

Flamingos........ 65

Fly-birds ......... 49

- Catchers ...... 36

Francolines.......6 61

Fratercula ......... 77

Fregilus .......... 48

Frigate-bird....... 81

Fringilla......... 43

___ ......... 44

Fulica........... 73

- Proper........ 74

Galbula.......... $51^{\circ}$

Gallinacex........ 13

- $-\ldots \ldots \ldots . . . .58$

Gallinula ......... 74

Gallus............6 60

Ganga...........6 61

Garrots.......... 82

Garrulus.......... 46

Geese ............ 81

— Brandl ......... 82

- - Soland ......... 81

Glareola.......... 65

Glaucopis......... 45

Gnat-snappers...... 36

Goat-suckers ....... 42

Godwits.......... 71

Goldfinches ........ 44

Gracula........... 39

Grakles........... 39

Grallx............... 13

- - ..........6 64

Graucalus.................... 35

Griffon............ 16

Grimpeurs ......... 13

Grossbeaks........ 44

Grous ............ 61

Grus ............6 68

- - Proper ....... 68

Guans. .......... 59

Guillemots........ 76

Gymnocephalus ..... 37

Gymnoderes ........ 38

Gypaëtos .......... 16

$\ldots \ldots \ldots .18$

Gypogeranus ........ 22

Hæmatopus . . . . . . 67

Halieus. ........... 80

Hallætus. . . . . . . . 24

- $\ldots \ldots \ldots .25$

-_ - Proper.... 25

Halodroma......... 72

Hardbeaks........... 45

Itarles... . . . . . . . 83
Page.

Harpyia .........24

Hawks (fishing)..... 24

Hemipodius. ........ 62

Herons . . . . . . . . . 69

- Night......... 69

Hians ............. 70

Hiero-falco........ 19

Himantopus........ 72

Hirundo........... 41

Hoazin ........... 60

Hoccos.......... 59

Hoërotaria ......... 49

Hoopoes........... 48

Hornbills .......... 50

____ Psittaceous.. 53

Horsemen.......... 72

Humming-birds . . . . 49

Ibis.......... 70

Icterus .......... 45

Ignobites ......... 19

- _ _.........2 21

Indicators .... $\ldots \ldots 53$

Jabiru........... 69

Jacamar............ 51

Jacana............ 73

Jacoos............. 59

Jays............. 46

Kamichi.......... 73

Kingfishers.......... 50

Kite............ 21

Knots .......... 71 .

Labbes........... 79

Lagopus... ....... 61

Lamellirostres...... 76

______ _..... 81

Langrayen .......... 34

Lanius............. 14

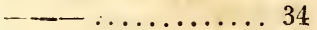

_- Proper....... 34

Lapwings ........6 67

Larks.............. 42

_- Sea ......... . 71

Lavandieres........4 41

Lestris........... 79

Limosa. ........... 71

Linaria........... 44

Linnets.......... 44

Lobipes.......... 72

Longipennes ....... 75

- …...7 78

Lonirostres........6 65

Lophrophores ...... 61

Loxia.............. 44

Lyre-tails . . . . . . . . 39

Machetes......... 72 
INDEX TO THE ORNITHOLOGY.

Page.

Macreuses......... 82

Macrodactyla......6. 65

Macrotarsus.......... 72

Mænura .......... 39

Malcohas......... 53

Manakins.......... 40

Martins..........4 41

Mauves........... 79

Meleagris......... 59

Men of war birds.... 81

Mergansers ........8 83

Mergus .......... 76

Merops............. 49

Microdactylus......6 68

Millouins ......... 82

Milvus............ 21

- - ........... 26

- - Proper....... 26

Mitoux........... 59

Mormon.......... 77

Morphnus......... 24

-

Motacilla .......... 40

- - - ........44 4

Moustaches ......... 43

Muscicapa ......... 36

Muscipata......... 37

Muscipata................. 36

Mycteria........... 69

Myothera......... 39

Naked-necks........ 38

Napauls ..........6 60

Nectarinia ........4 48

Neophron......... 18

Nightingales....... 40

Nisus............. 26

Nobiles.......... 19

Noctua...........27

- - .......... 29

Nocturnæ......... 15

- ............ 27

Noddies.......... 80

Nudipes........... 29

Numenius........... 70

Numida ..........6 61

Numidiciæ........6 68

Nutcrackers....... 47

Nuthatches........ 46

Nyctea.......... 29

Ocypterus

- _. Proper .... 60

pterus......... 34 Pheasant ........6 60

OEdicnemus........6 67 _— Crested....6 60

Onocrotalus........ 80 Phene........... 16

Open-beaks......... 70 Philedon............ 39

Opisthrocomus ..... 60. Phœnicopterus.......65 65

Oriolus............ 38 Piauhau ......... 37
Page.

46

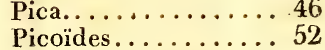

Picucules.......... 48

Picus............ 52

- Proper.........5 52

Pigeons. ..........6. 62

___ Greenland . . 76

Pintado..........6 61

Pipra........... 40

Pitpits ..........4 46

Pitylus ............ 44

Platalea .......... 70

Ploceus........... 43

Plotus........... 81

Plovers.... ......6 66 Long-legged. . 73

Plumatx........... 34

Podarge .......... 42

Podiceps........... 76

Pogonias........... 54

Polyplectrum....... 59

Porphyrio......... 74

Pratincoles.........6 65

Pressirostres. .......6 64

- - _.......6 66

Prionites.......... 50

Prions. . ........ 78

Procellaria......... 78

-__ Proper..... 78

Procnias .......... 38

Promerops........ 48

Psaris ........... 35

Psittacus........... 55

Psophia...........6 68

Pterocles......... 61

Pteroglossus........ 55

Puffins .......... 78

Puffinus ........... 78

Purres.......... 71

Pyrgita.......... 43

Pyrrho-Corax........ 38

Pyrrhula......... 44

Quails...........62 62

Q. American....... 62

Quans........... 59

Rails........... 73

Rallus............ 73

Rhamphastos....... 54

_-__— Proper.. 55

Recurvirostra...... 72

Regulus ......... 40

Remiz......... 43

Rhea..........6 66

Rhynchops........ 80

Rollers .......... 47

Ruffs and Reeves ... 72

Rupicola......... 40

Rynchoca......... 71 


\section{INDEX TO THF ORNITHOLOGY.}

Sand-pipers. ...... Page.

- - . . . . . . 72

- - - .......71

Sarcoramphus....... 18

Sasa..............6 60

Satyrus..........6 60

Savacous.........66 68

Saxicola ..........4 40

Scansores......... 13

-

Scolopax......... . 70

-_—_ Proper. . . . 71

Scops ...........29

Scopus ...........6 69

Screamers .........73

Scythrops.........55

Sea-dottrels........ 72

Sea Mews ......... 79

Sea Pies..........66 67

Serpentarius ....... 22

Shore-birds.........6 64

Shovelers......... 82

Shrikes........... 34

Sitta ..........4 46

Skimmers. ....... 80

Snipes........... 71

72

Spheniscus......... 78

Spoon-bills.........770

Squatarola........667 67

Stares.............4 46

Starlings.......... 46

Stercoraires........79

Sterna............ 79

Stints ............. 71

Storks...........69 69

Straw-tails ......... 81

Strepsilas.........72

Strix ............ 14

$-\ldots . \ldots \ldots \ldots 27$

- $\ldots \ldots \ldots \ldots .28$

Struthio .........6 65

Sturnus.......... 46

Sugar birds ........ 49
Page.

Sugar-eaters....... 49

Sula. ........... 81

Sultans........... 74

Surnia............ 29

Swallows ........... 41

___ Sea.......79 79

Sylvia............ 10

Syrnium........... 29

Tachydromus ...... 67

Tadornes........... 83

Tamatias ........... 54

Tanagers ......... 35

__ _ Cardinals... 35

Euphones .. 35

Grossbeaks.. 36

___ Grosiots..... . 36

_-_. Proper..... 36 Ramphoceles 36

Tanagra.......... 35

Tantalus........... 70

Temia............ 47

Tenuirostres....... 34

- $\ldots \ldots . .48$

Terns ............ 80

Tetras..........6 61

Thrushes........... 38 Ant......... 39

Tichodroma........ 48

Tinamus........... 60

Tisserins............ 43

Titmice ........... 43

Todies .......... 50

Todus.............. 50

Torcols............ 52

Totanus.......... 72

Totipalmes....... 75

…........ 80

Toucans......... 54

Touracous ........ 57

Tridactylæ......... 52

Tridactyles......... 62

Tringa .........667

_- Psoper.......6.67 67
Trochilus. ....... Pagr.

Tropic-birds ........

Troglodytes........ 40

Trogon............ 54

Trumpeters........6 68

Turdus.......... 38

Turkies........... 59

Turnix ............. 62

Turnstones.......... 72

Tyrannus.......... 36

Ulula........... 28

Umbres ............ 69

Upupa.............. 48

- Proper.......48

Uria............. 76

Vanga............ 34

Vidua ............. 44

Virago............6 63

Vouroudrious......... 53

Vultur............. 14

-

- $-\ldots . . . \cdots .18$

Vulture............. 16 Proper........18

Waders............ 64

Wag-tails.......... 41

Wasp-eaters........ 50

Water-fowls ........ 74

Water Ouzels......... 39

Wattlebirds. ........45

Weavers............. 43

Whimbrels.........7 71

Woodcocks ......... 71

Woodpeckers........ 52

Wrens........... 40

Wrynecks......... 52

Xanthornus ....... 46

Ynambus ..........62 62

Yunx............62 62 


\section{PLATE I.}

pger.

n or fibula.

s (represented by a single bone). the union of the two clavicles. 



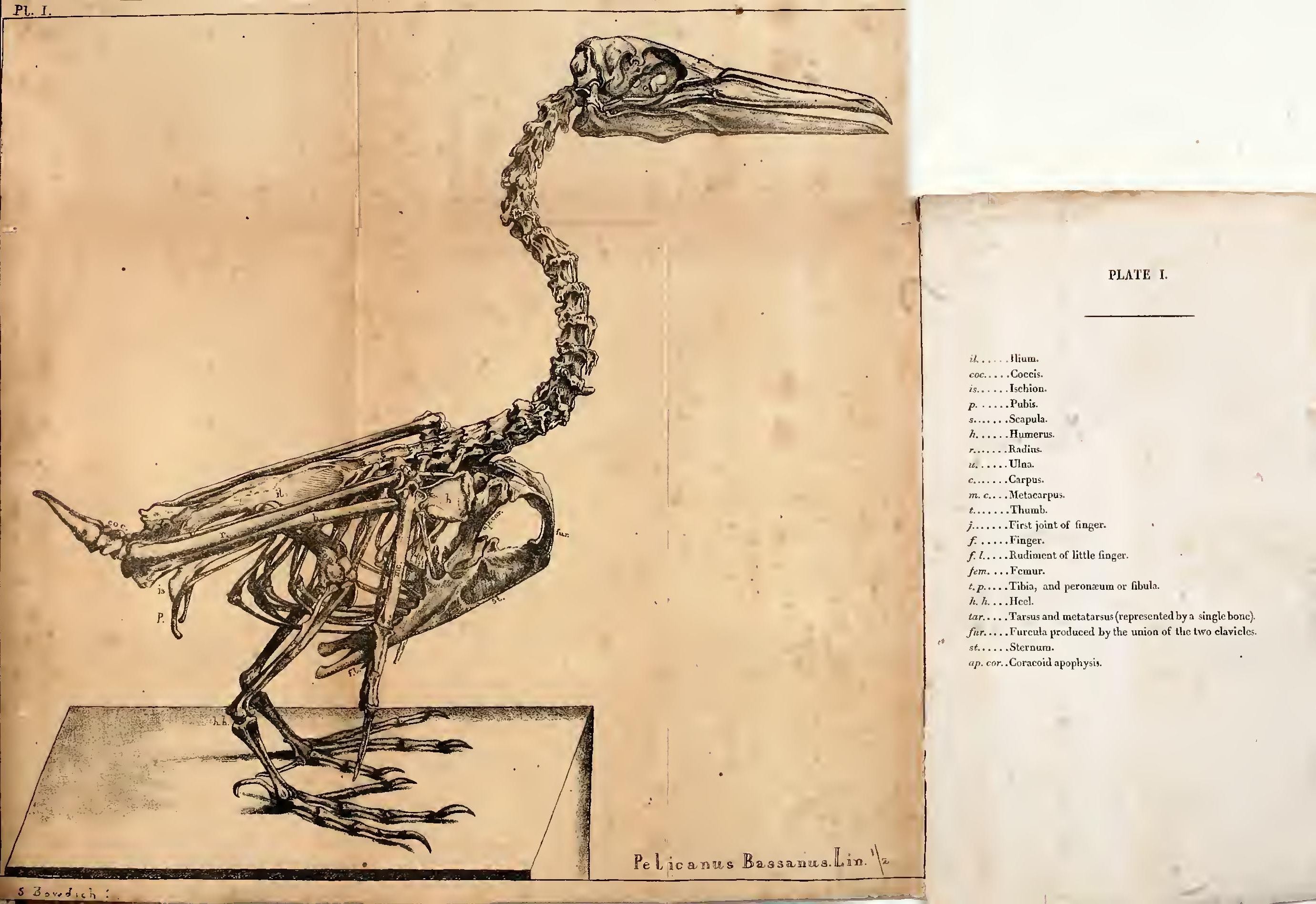


$2+1.12$ 


\section{PLATE II.}

FIG. I.

FIG. II.

FIG. XVI.

ces minores.

o majores.

ies or greater remiges.

saries or lesser ditto.

es scapularies.

FIG. XVII.

herus on which the scapularies are attached.

us and ulna .. secondaries

$\mathrm{nb}$

.. bastards

acarpus and joints. . primaries 



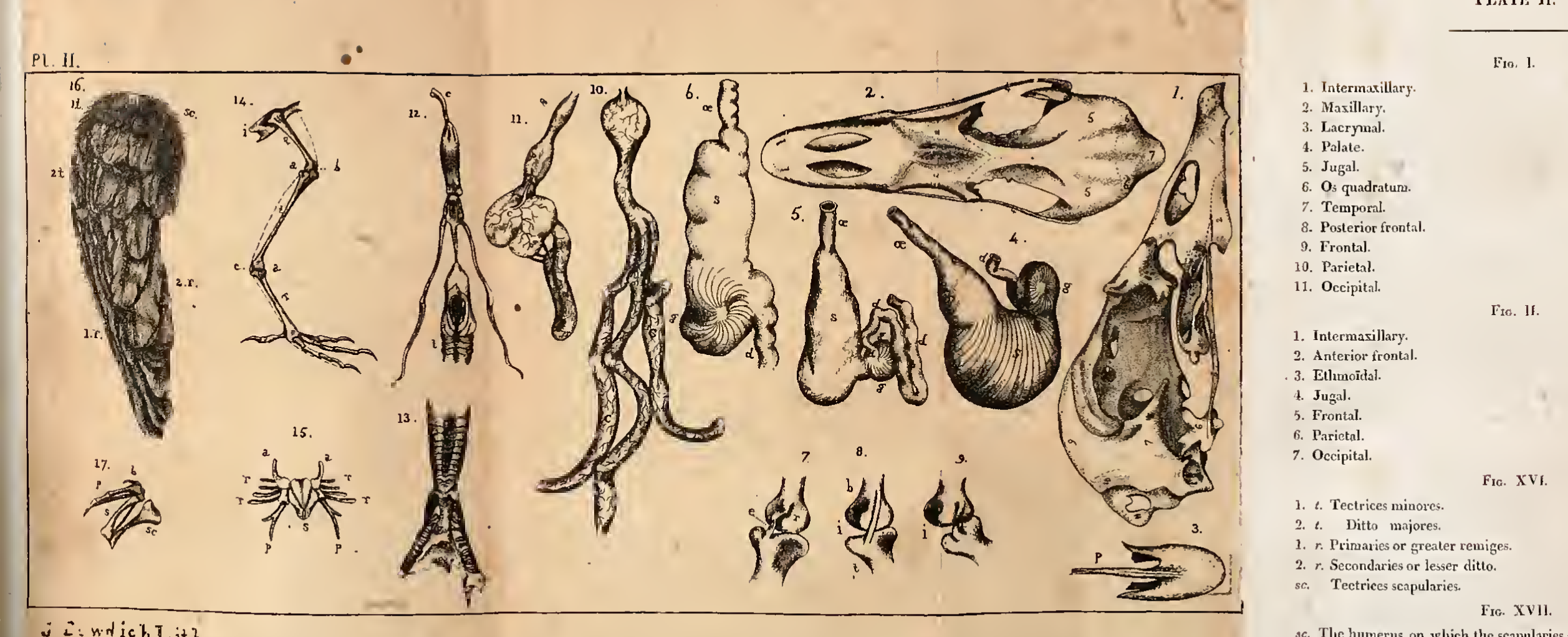




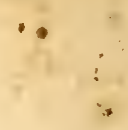

e

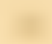

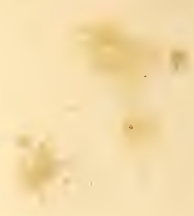

$7=$
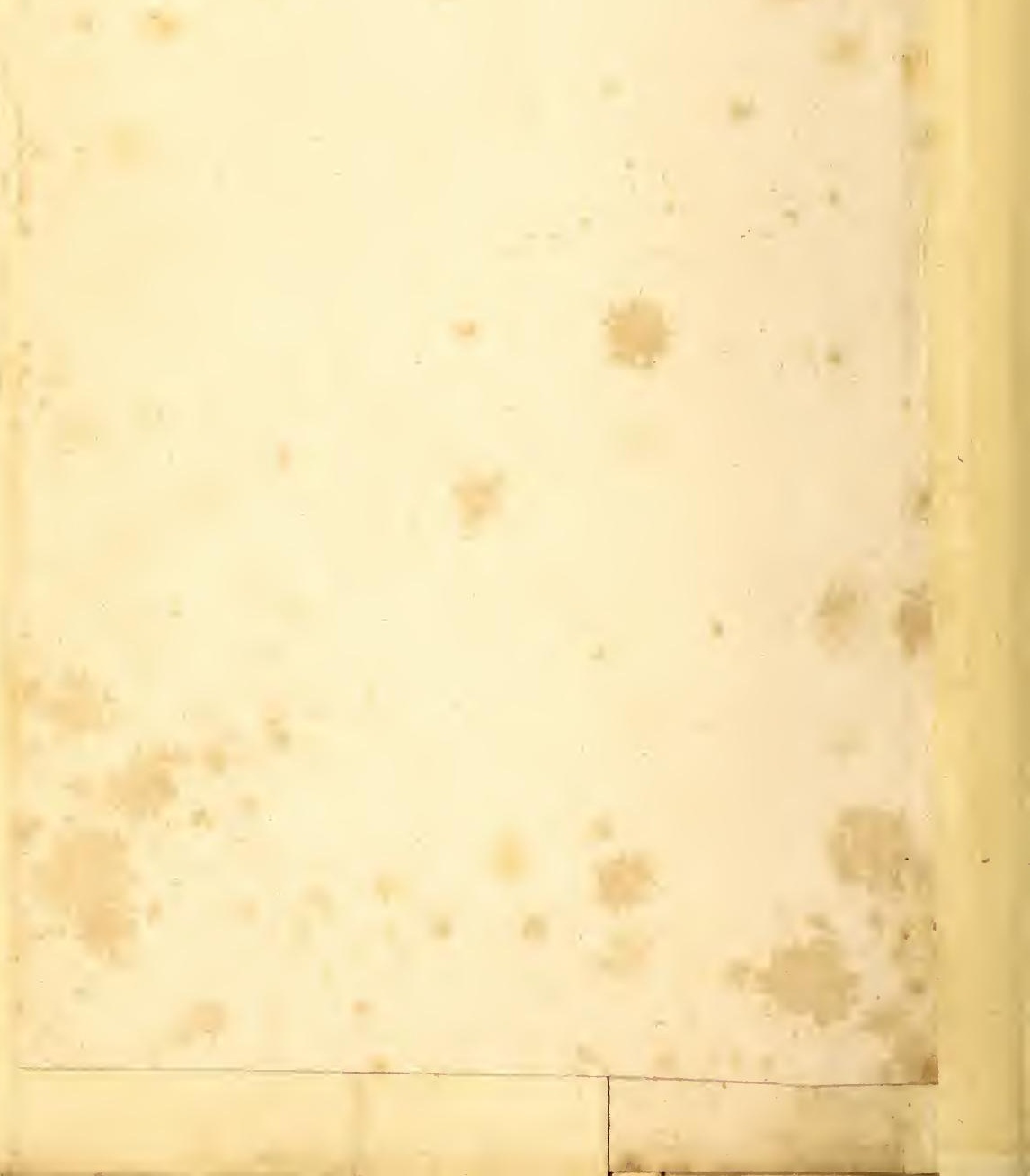


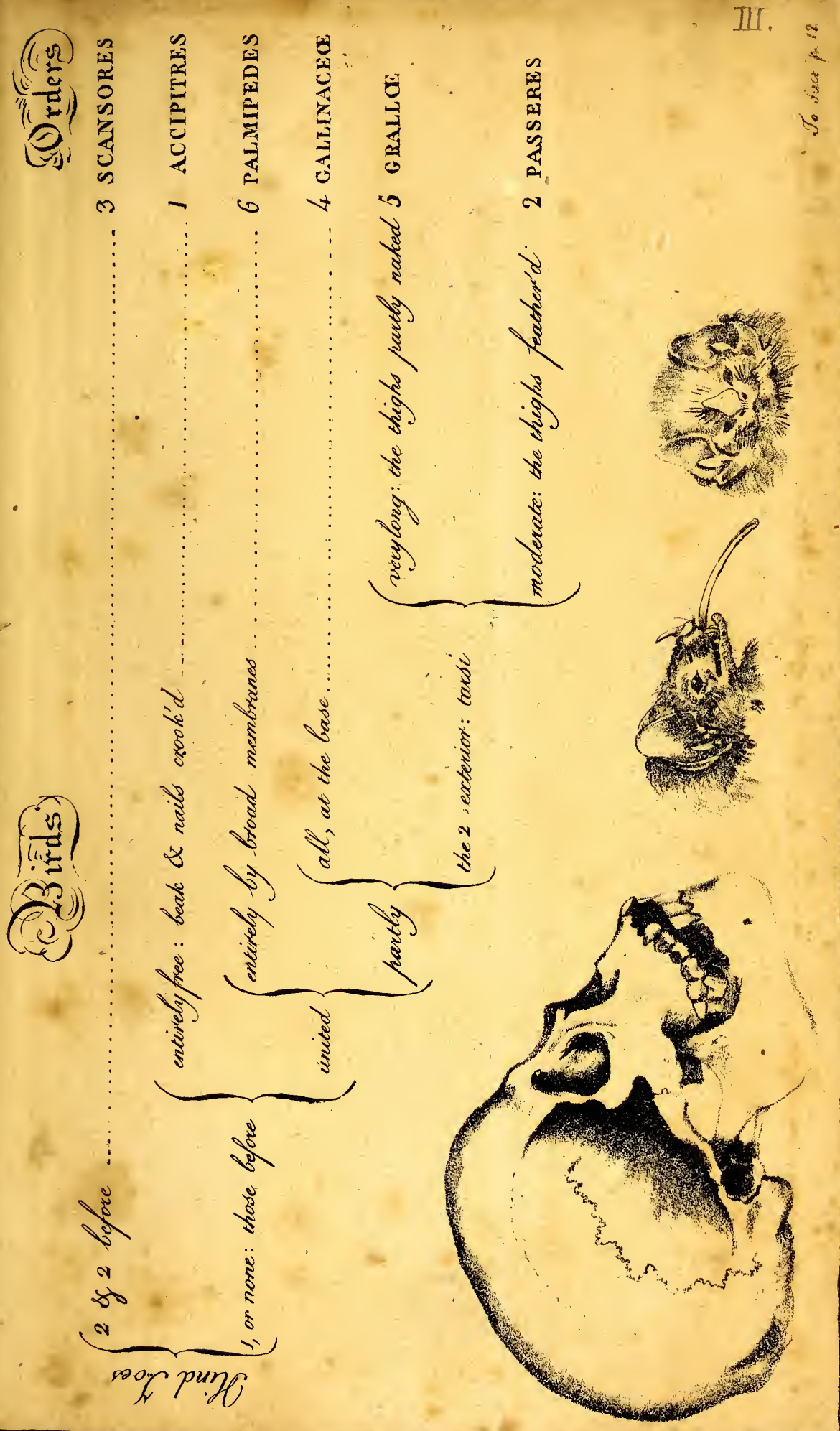


4
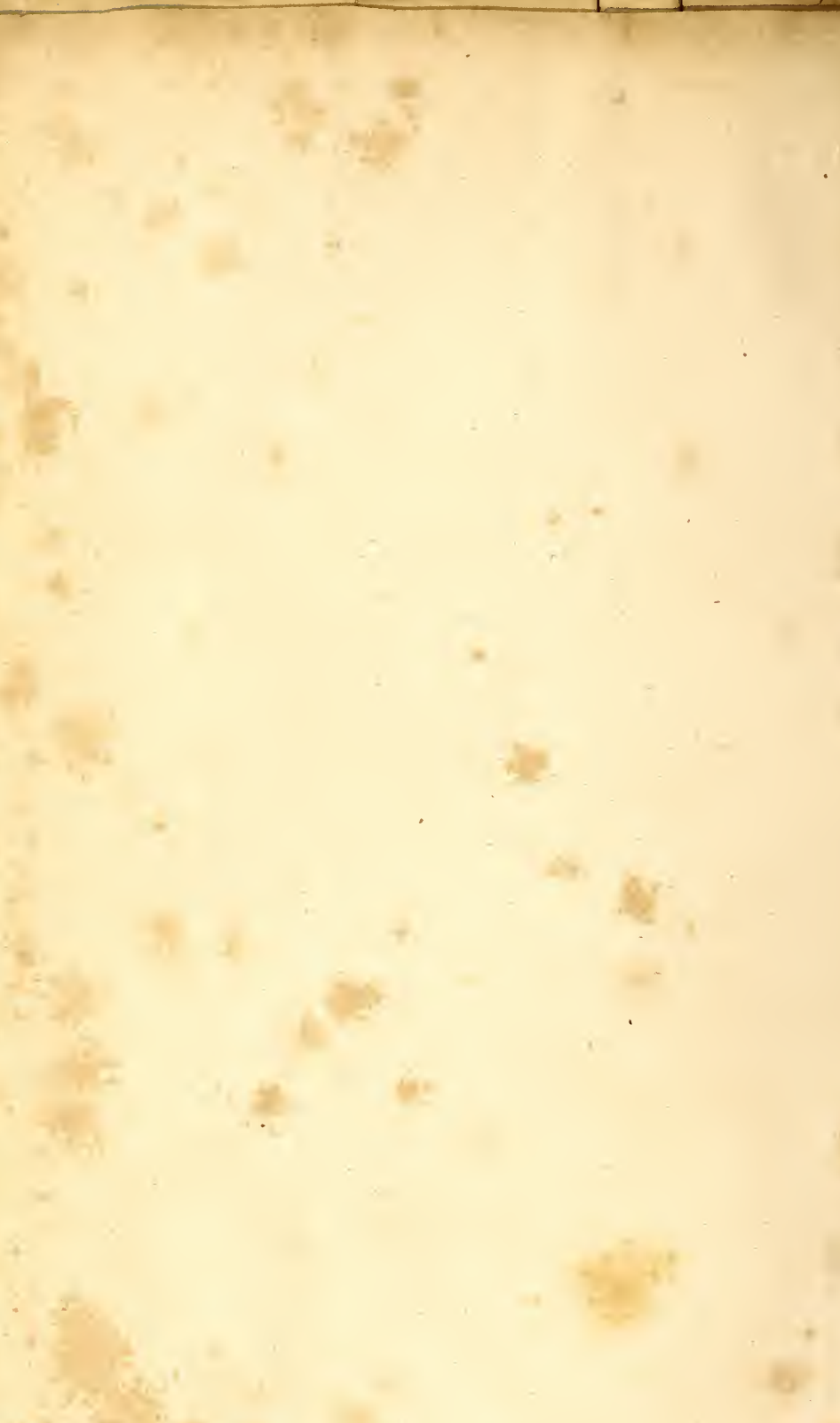

t4t

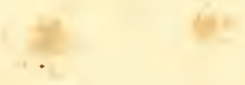




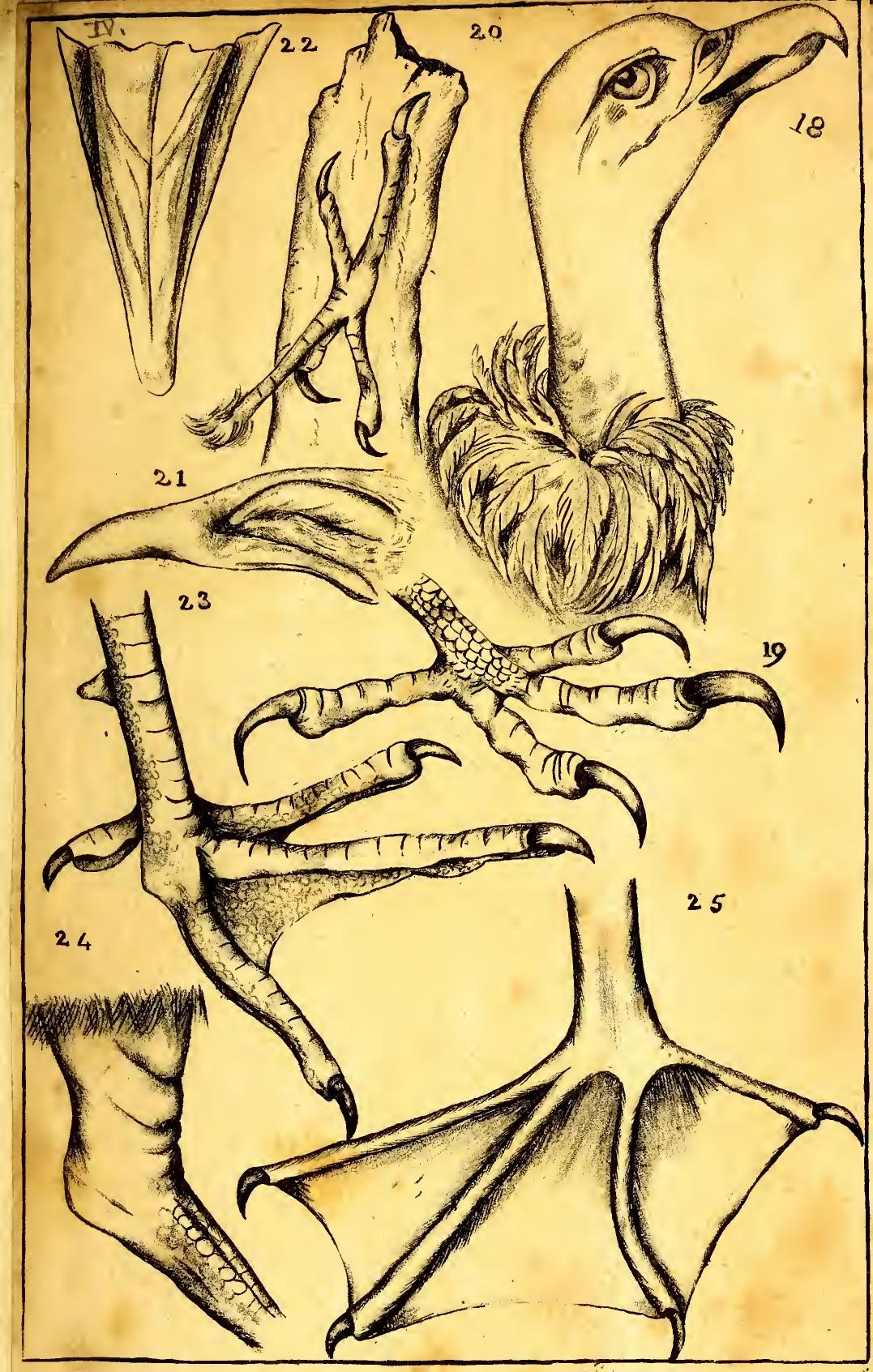



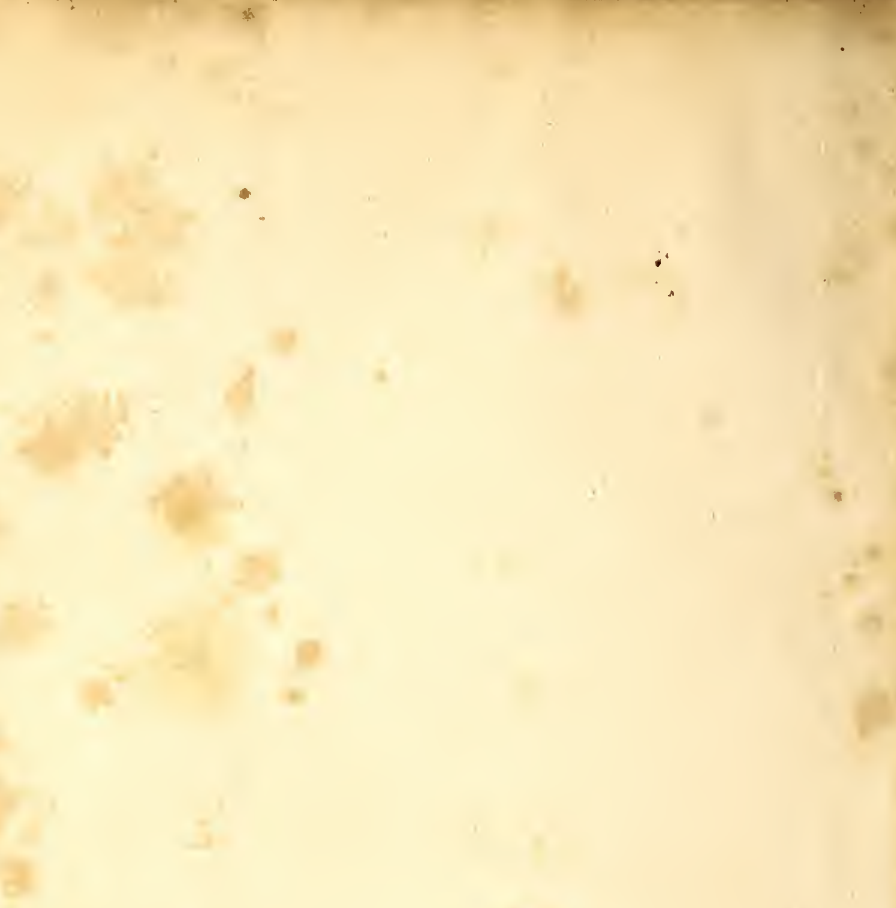

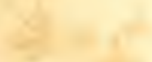
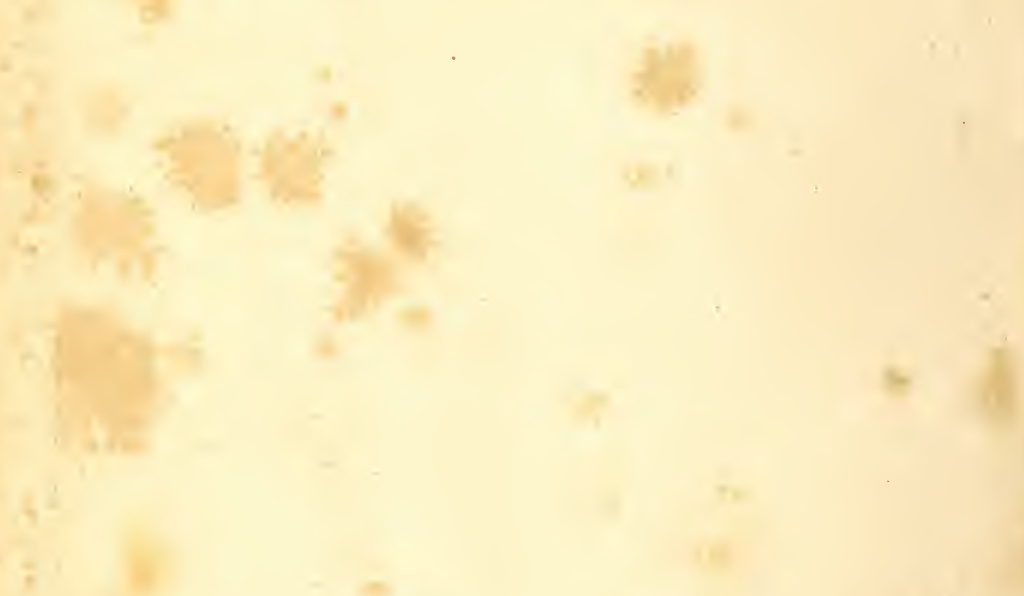

,
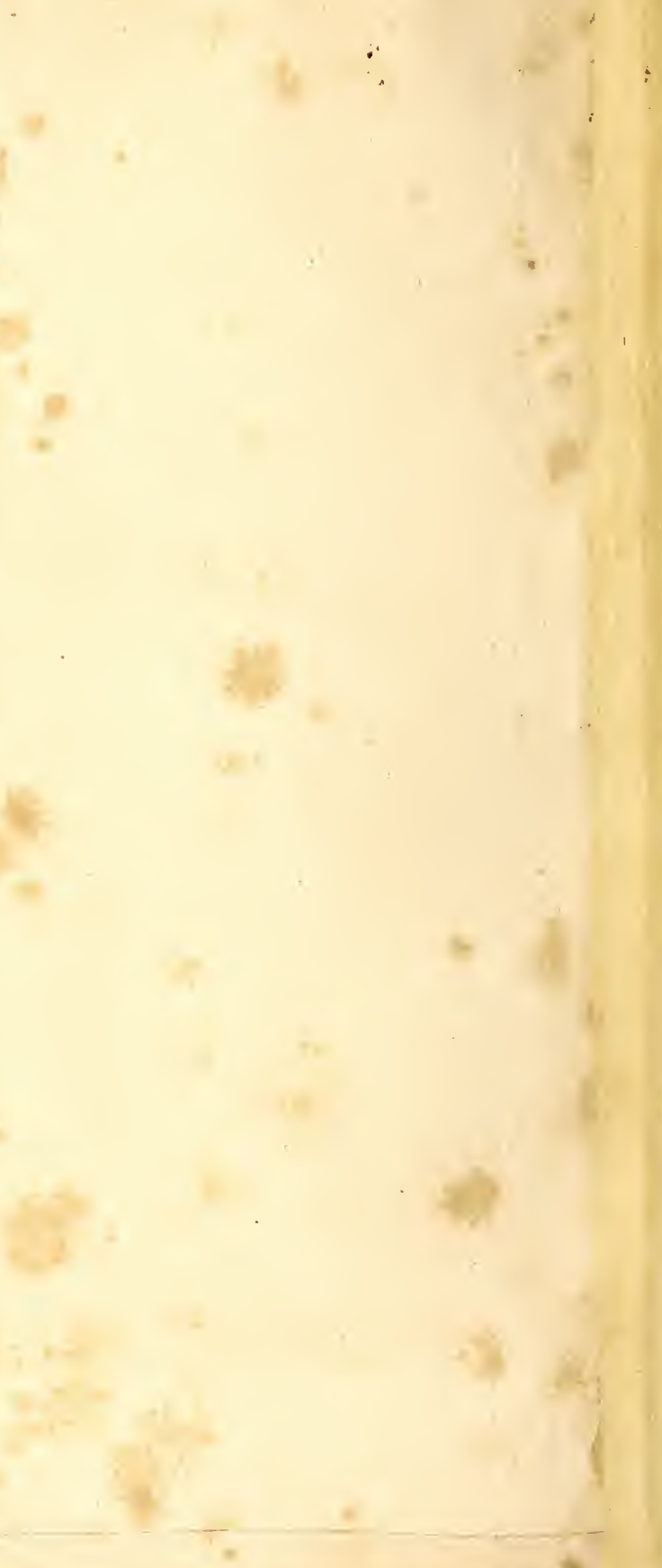



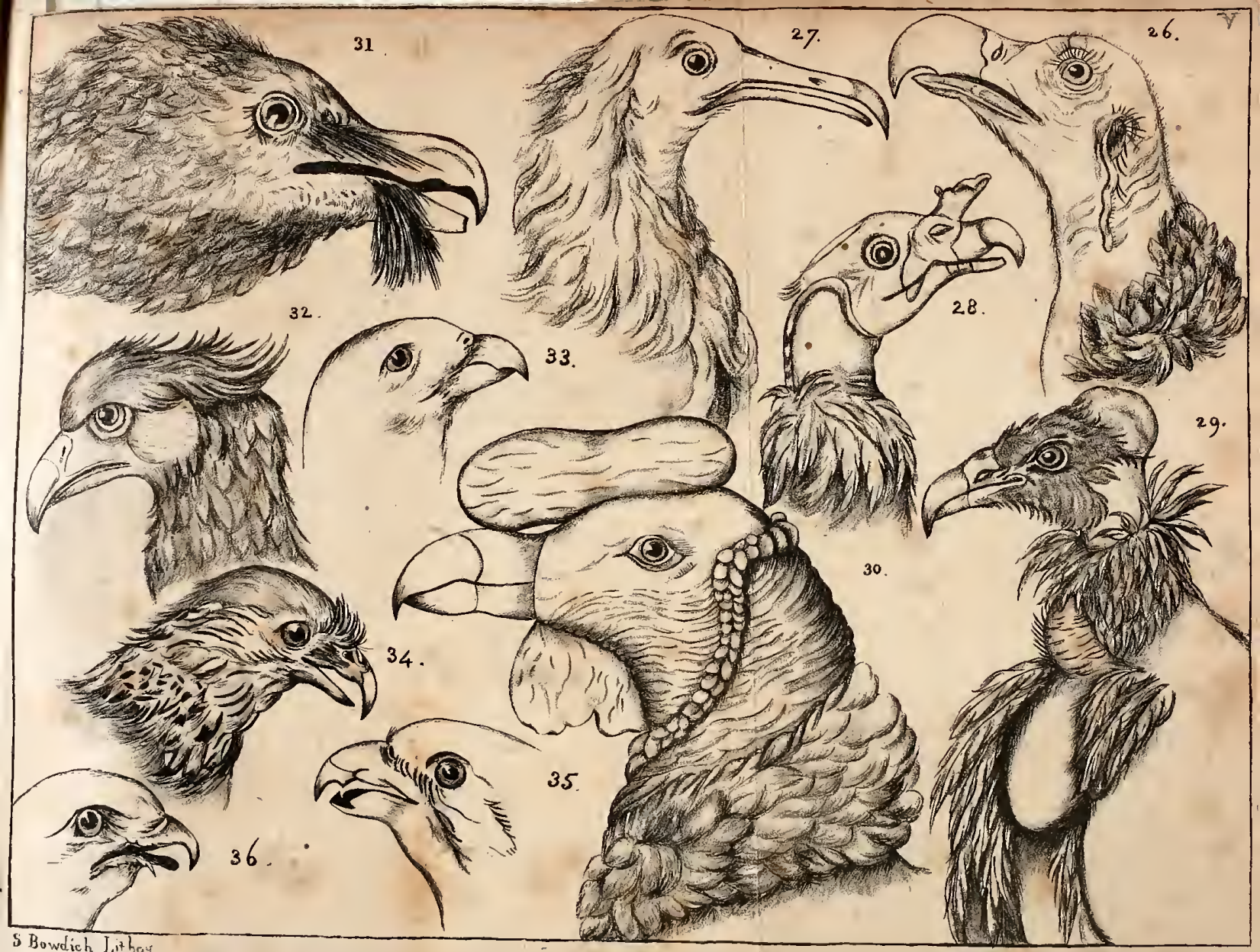

S Bowdich Iithoy 

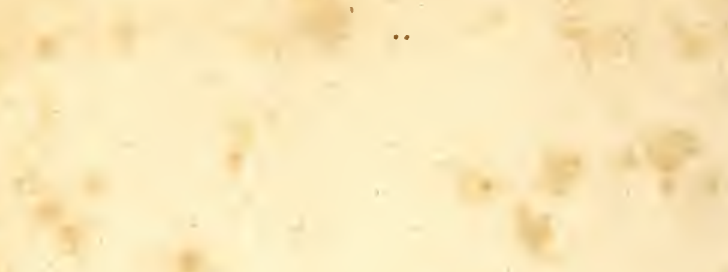

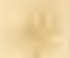

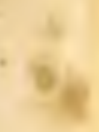

r

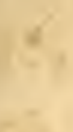

$+4$

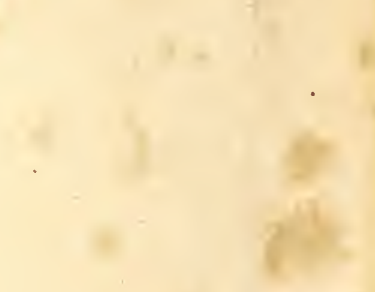

$\sqrt{2}$

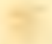

$r^{n}$

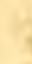

$4 .-2=0$

in 4

14

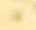

2

a

$\sqrt{2}$

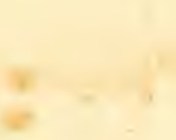<smiles>CCC</smiles>
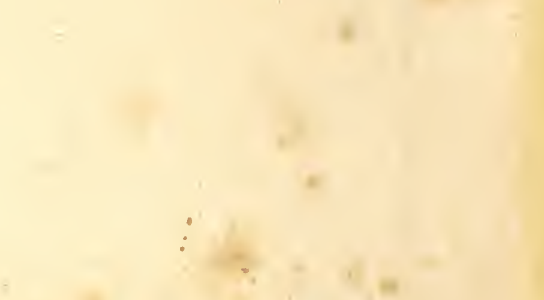

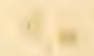

17.
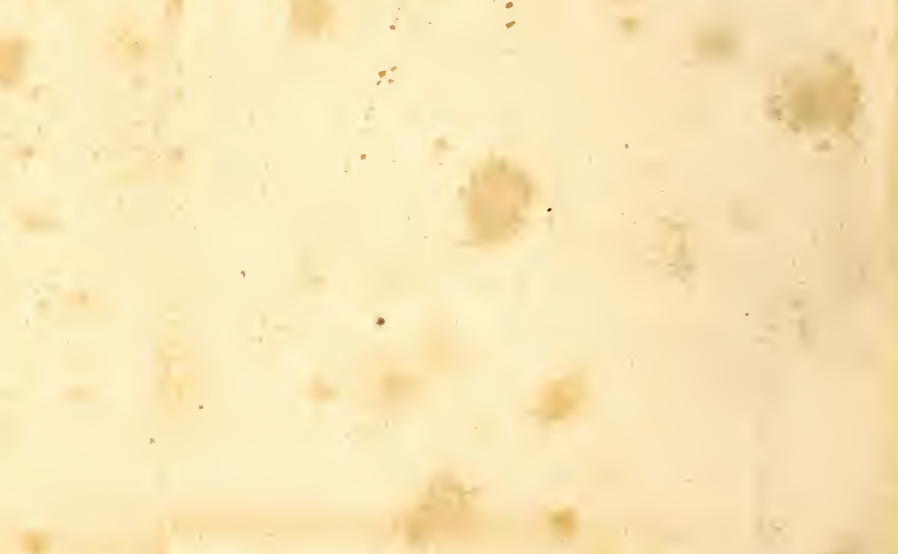

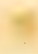

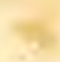

wa

$-6$

- pit ato

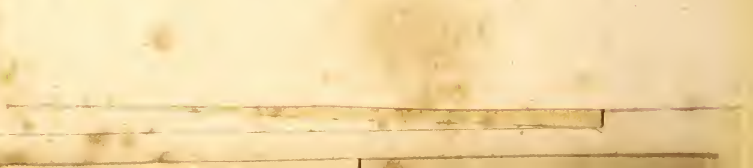




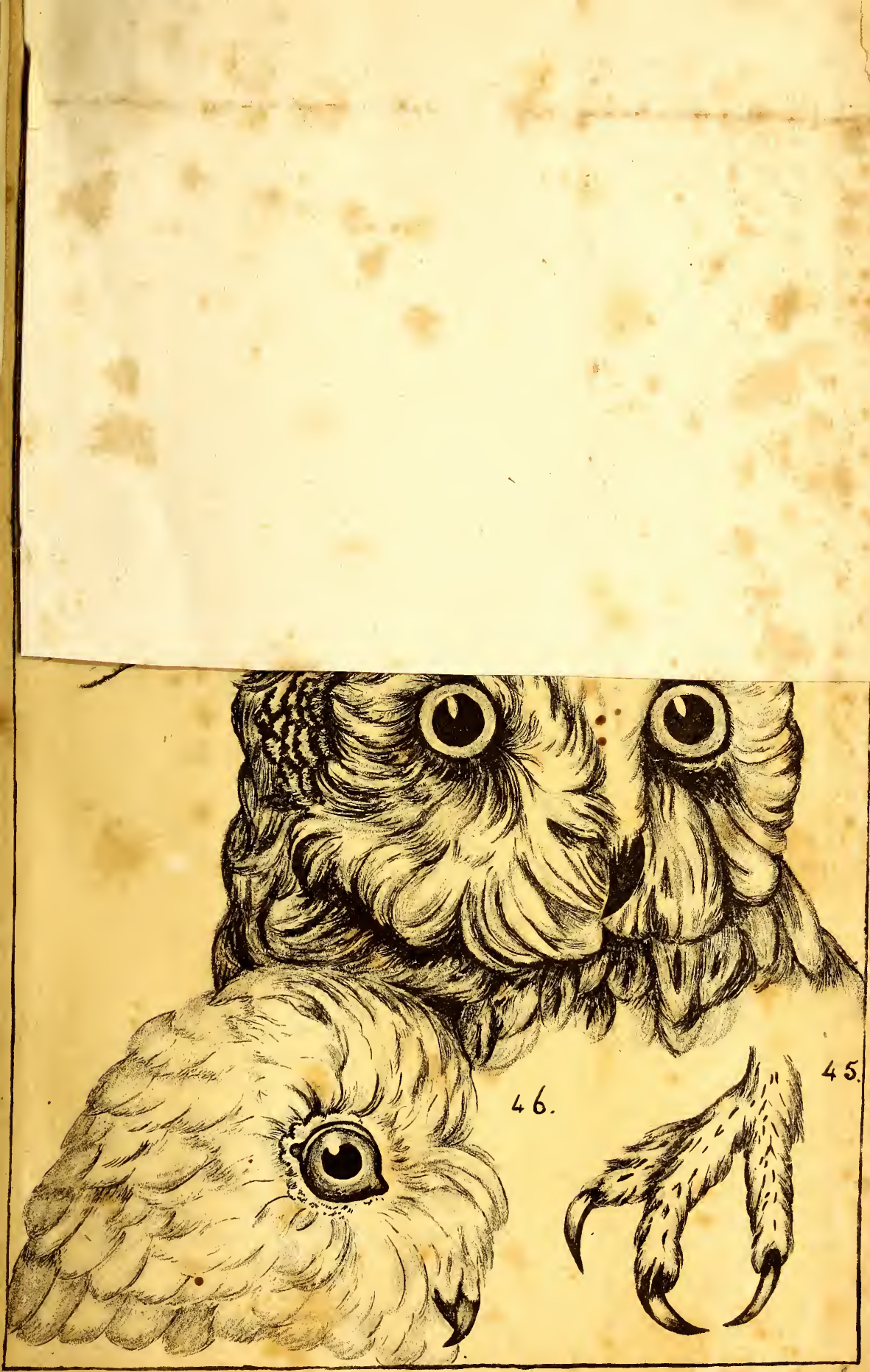

S. Bowdich. Lith: 



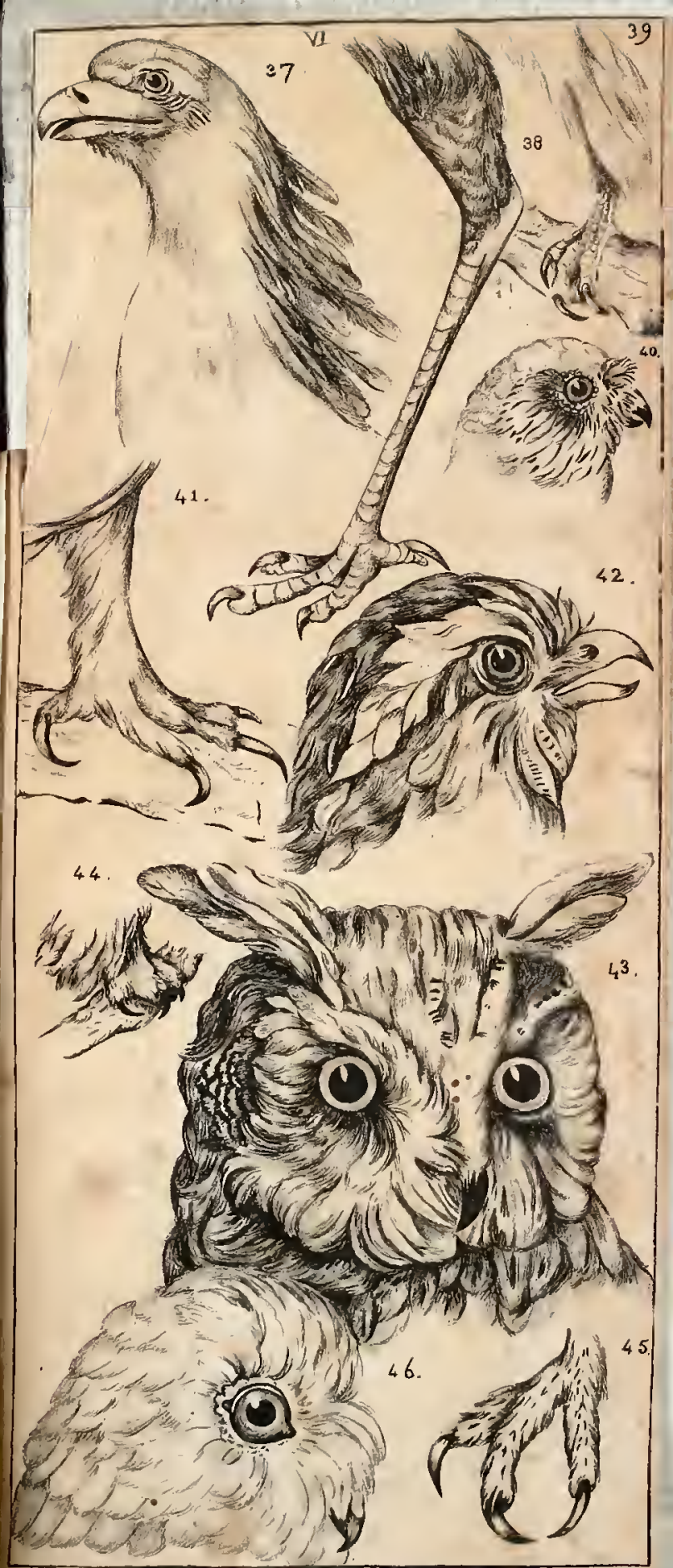

\section{S Bowdreh, Lith,}





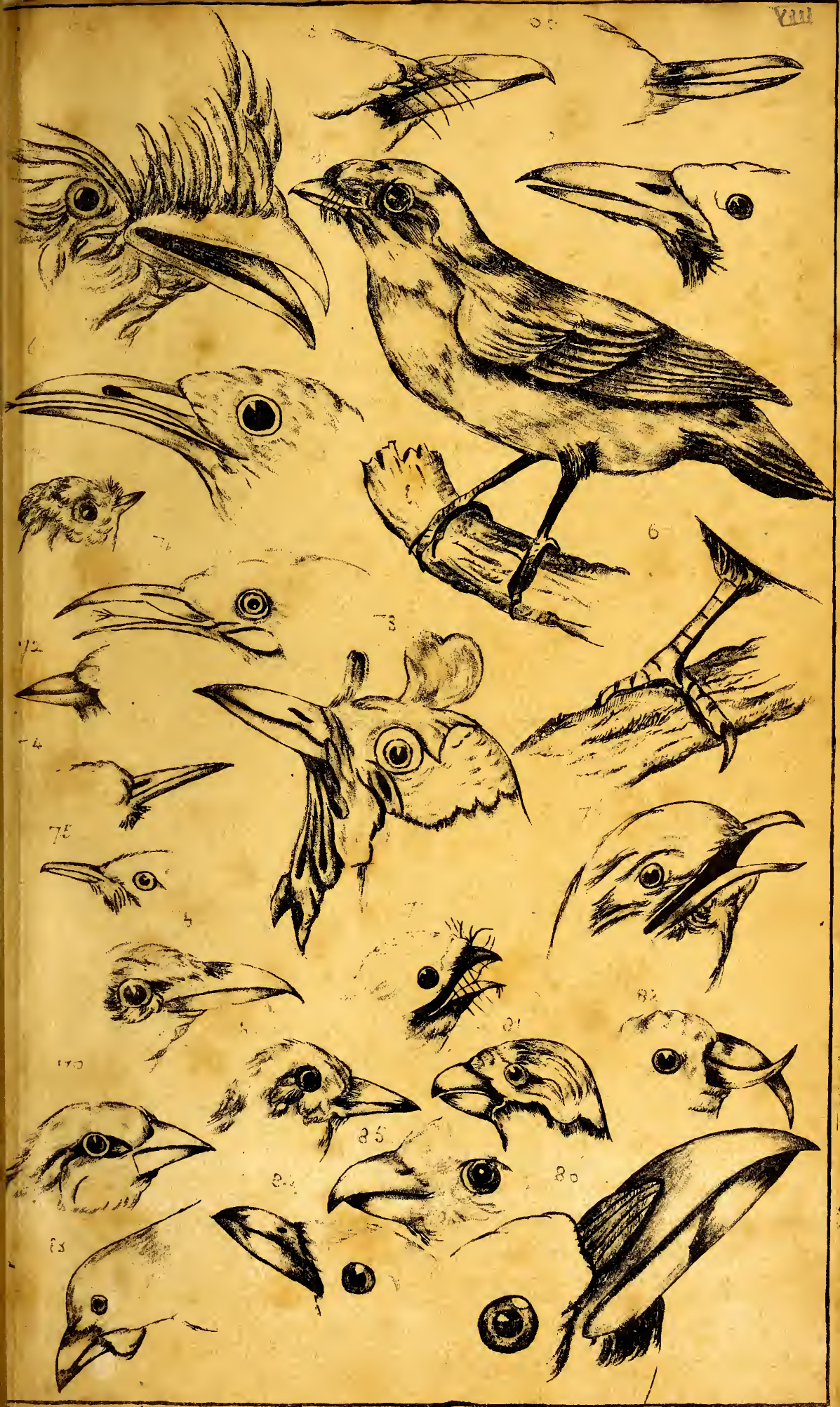

Bawrolich Loithog: 


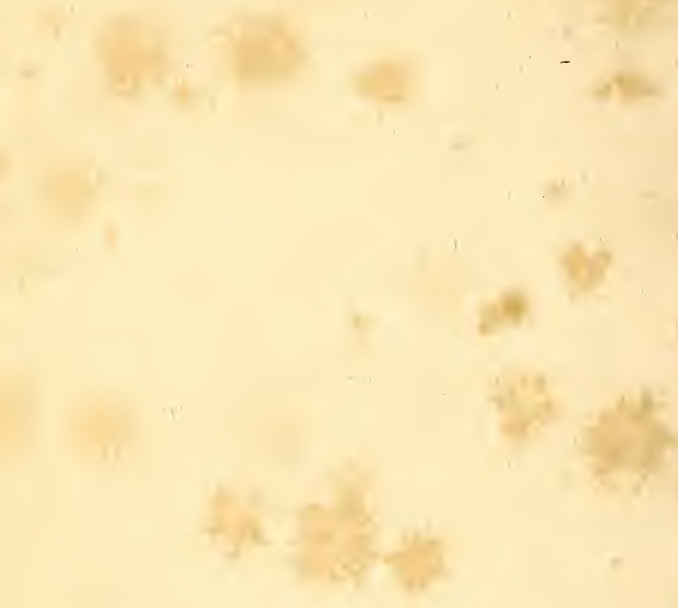

-
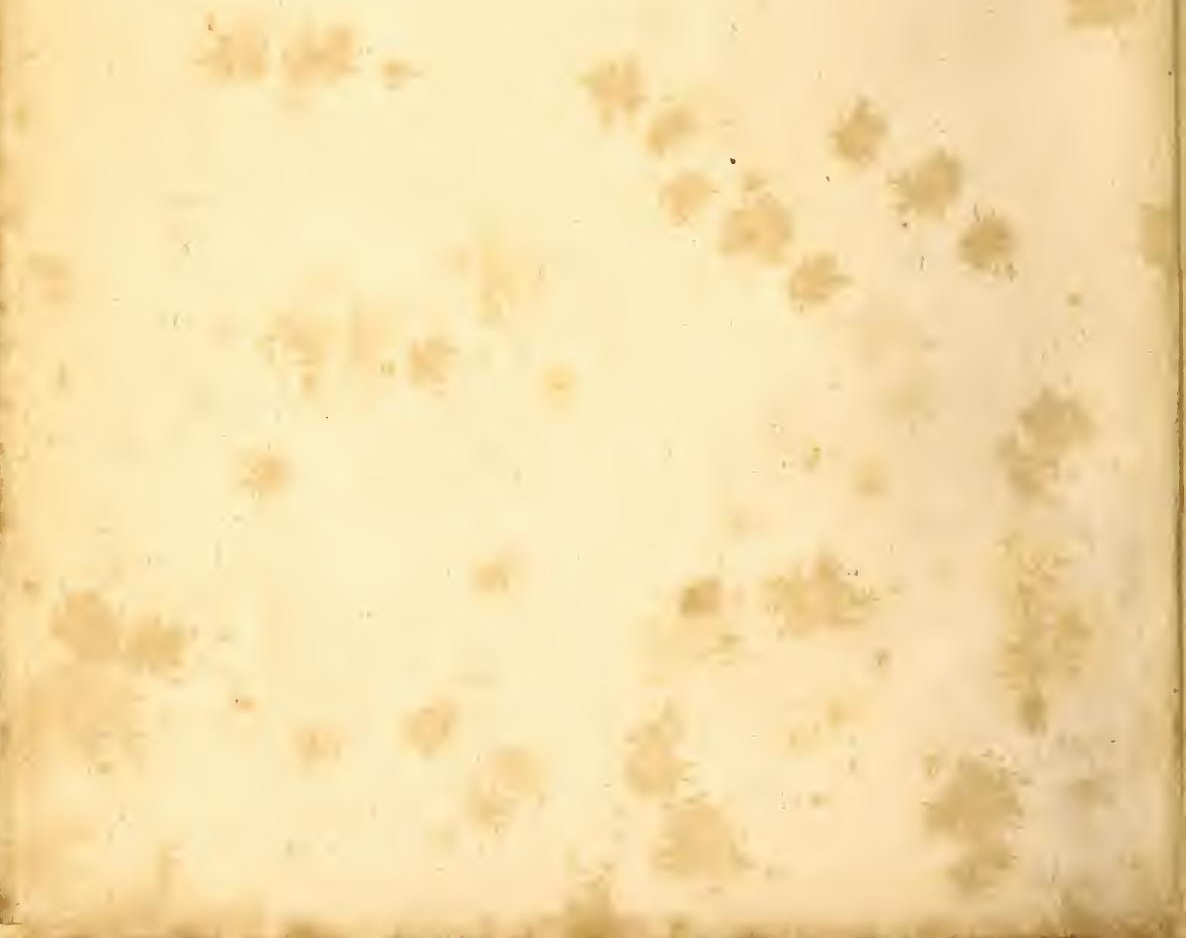


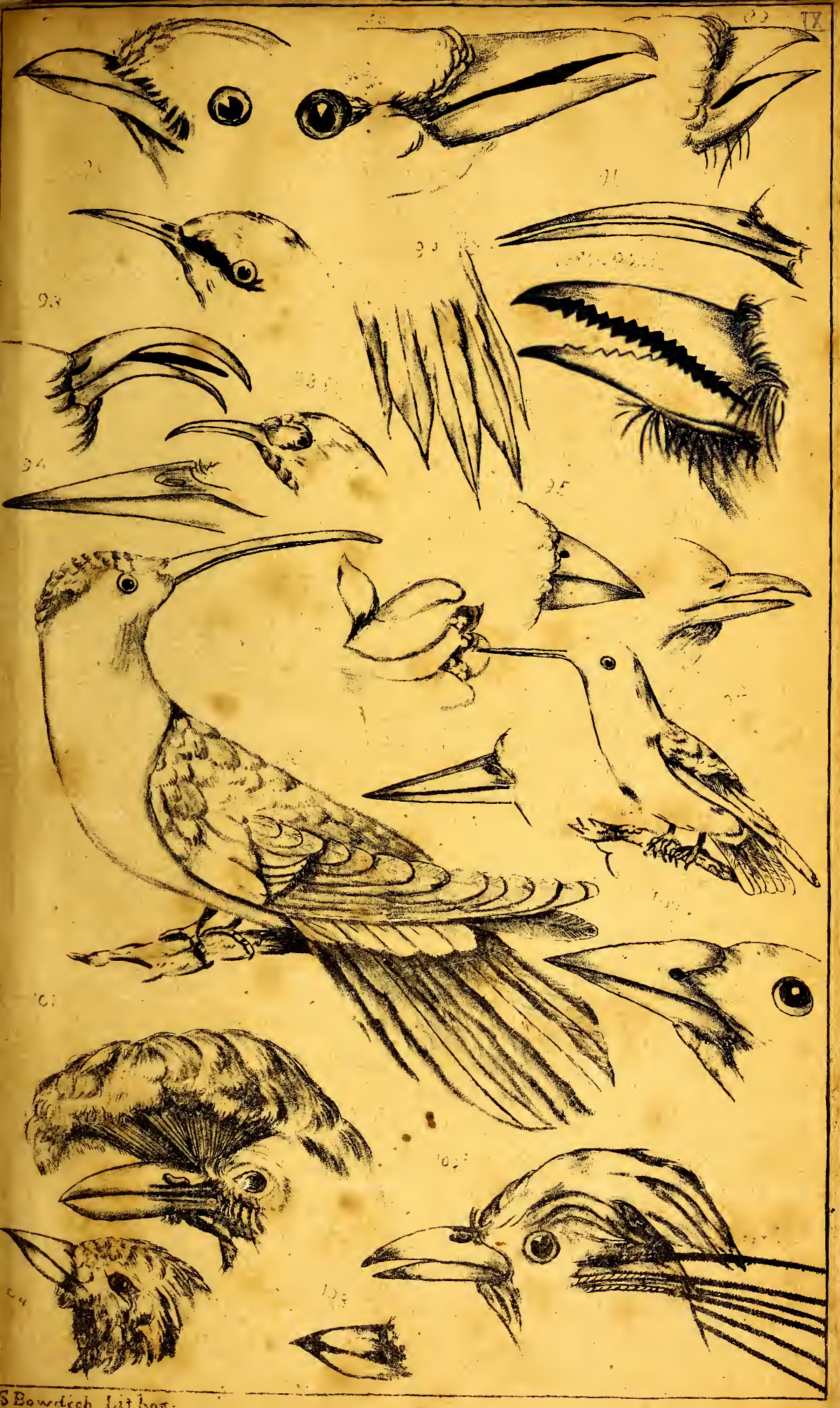



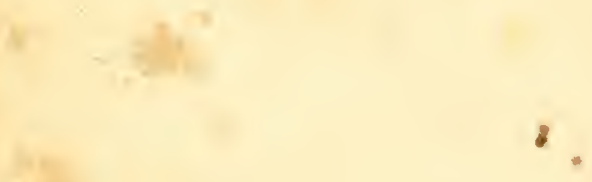

$+4$

4
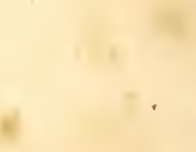


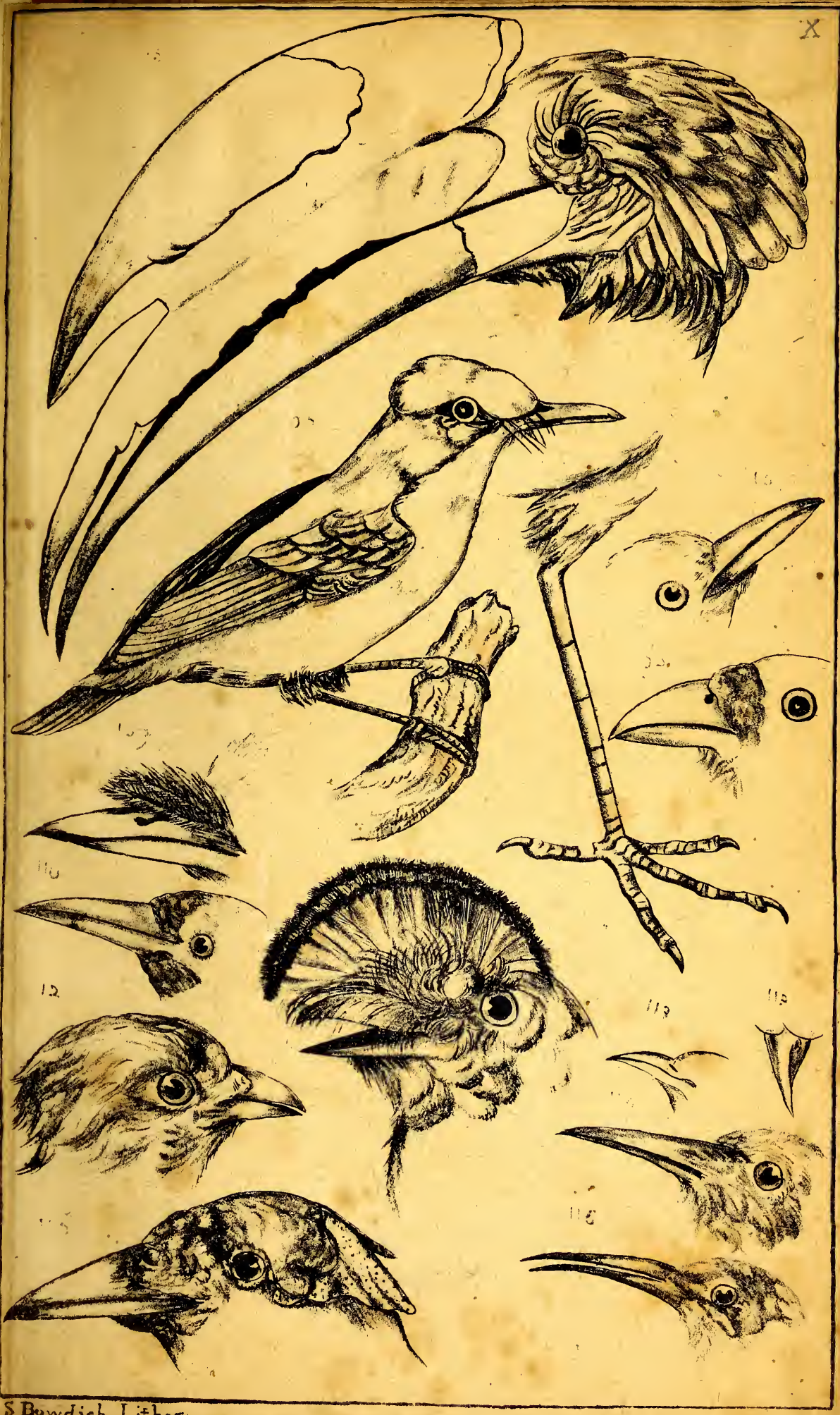




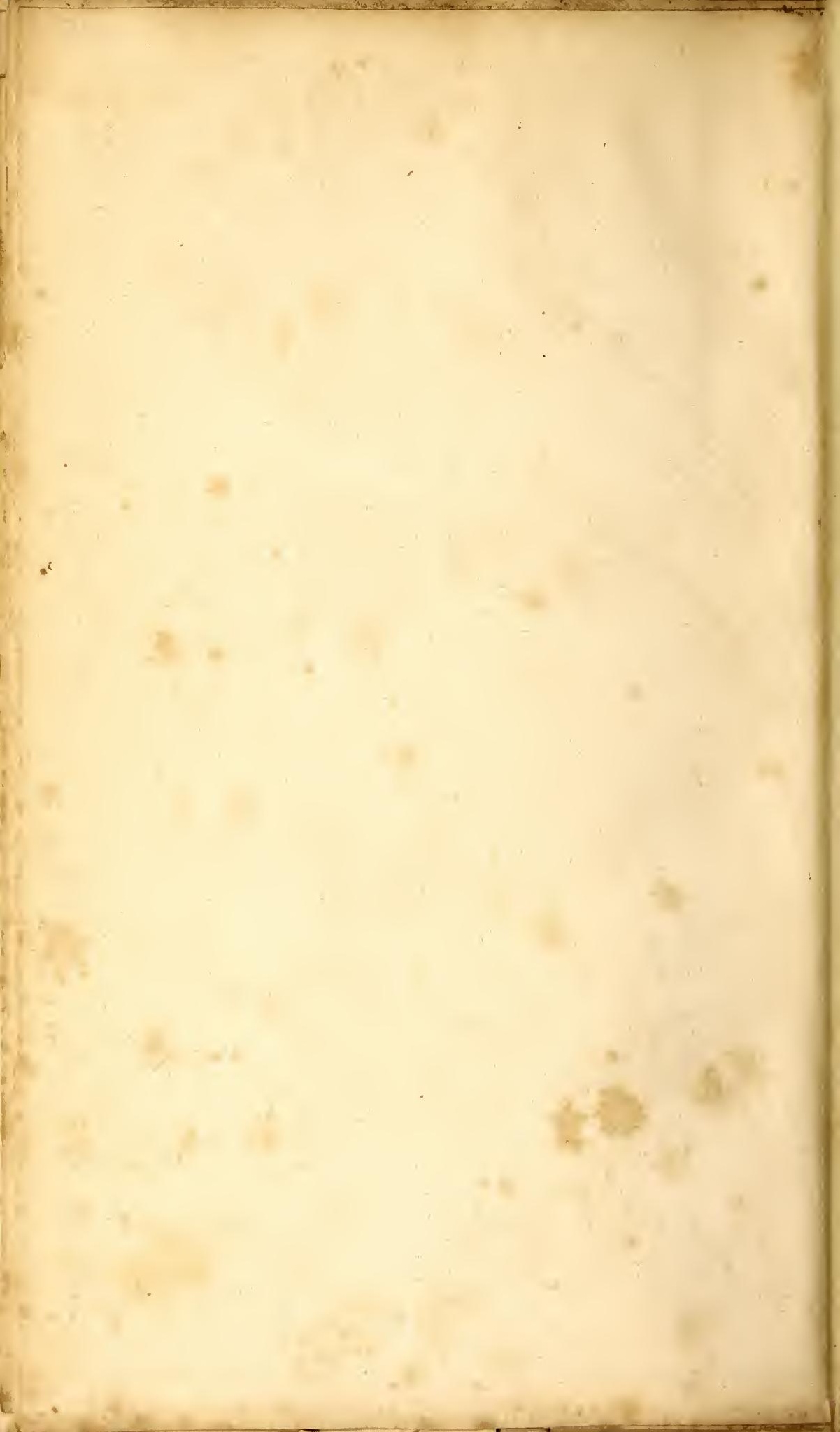




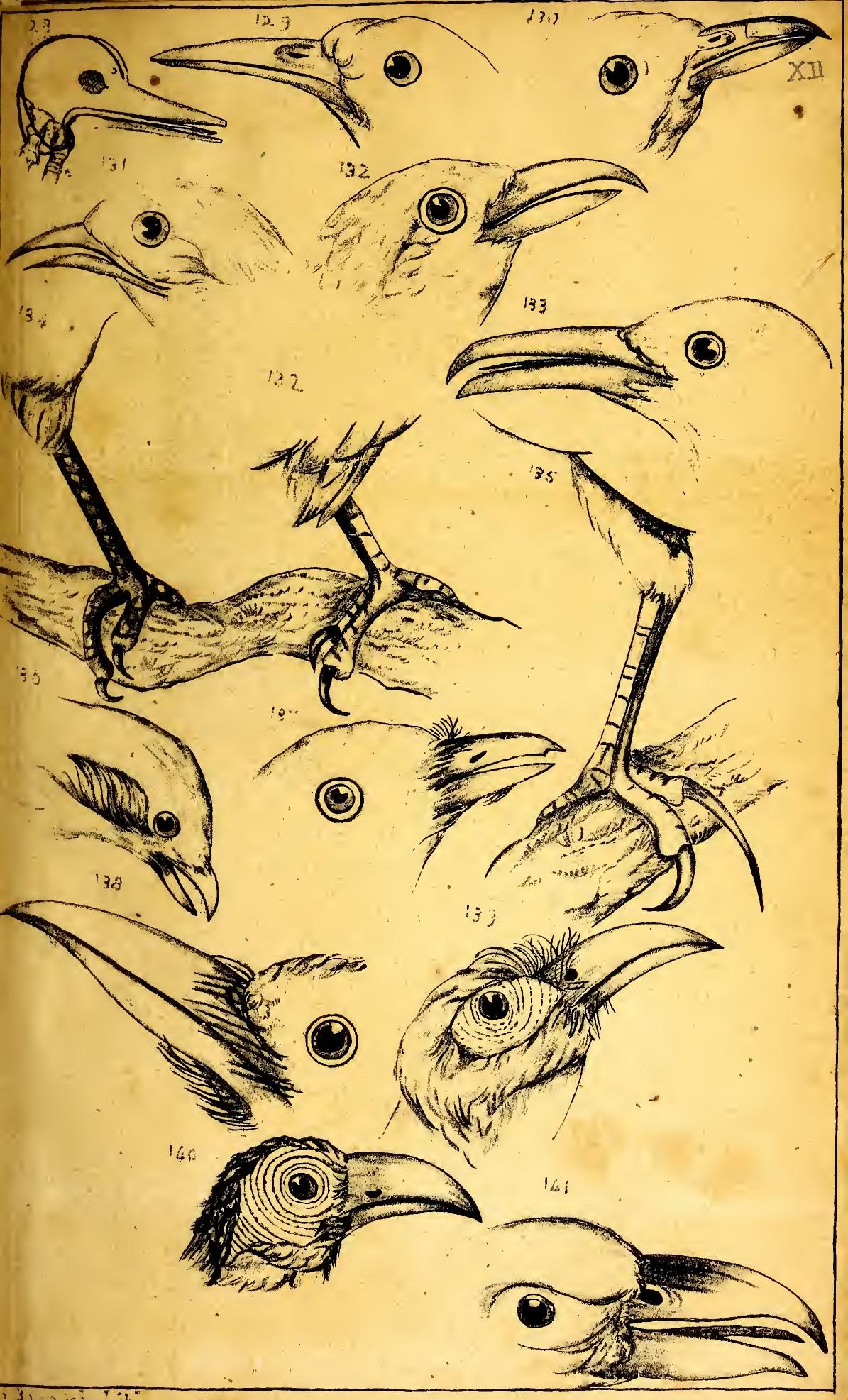




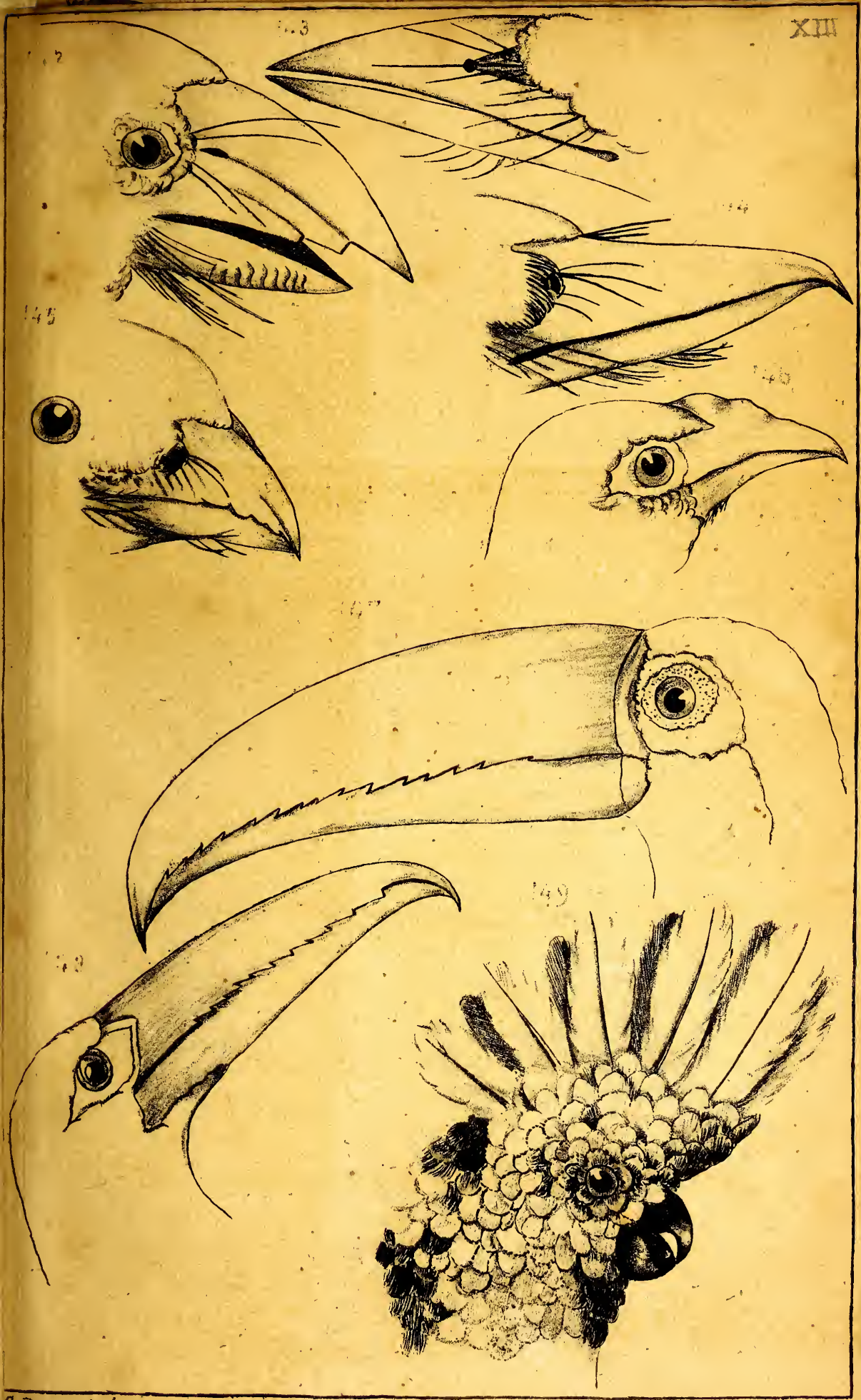

S3owneh Lifa. 


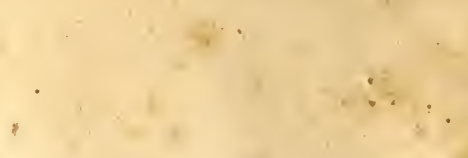

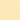
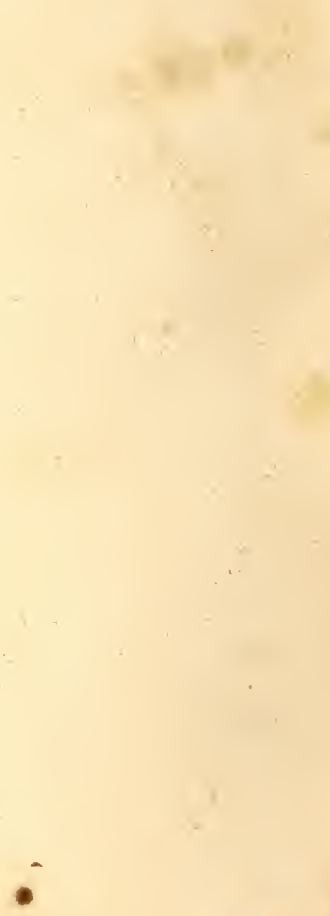

$-$ 


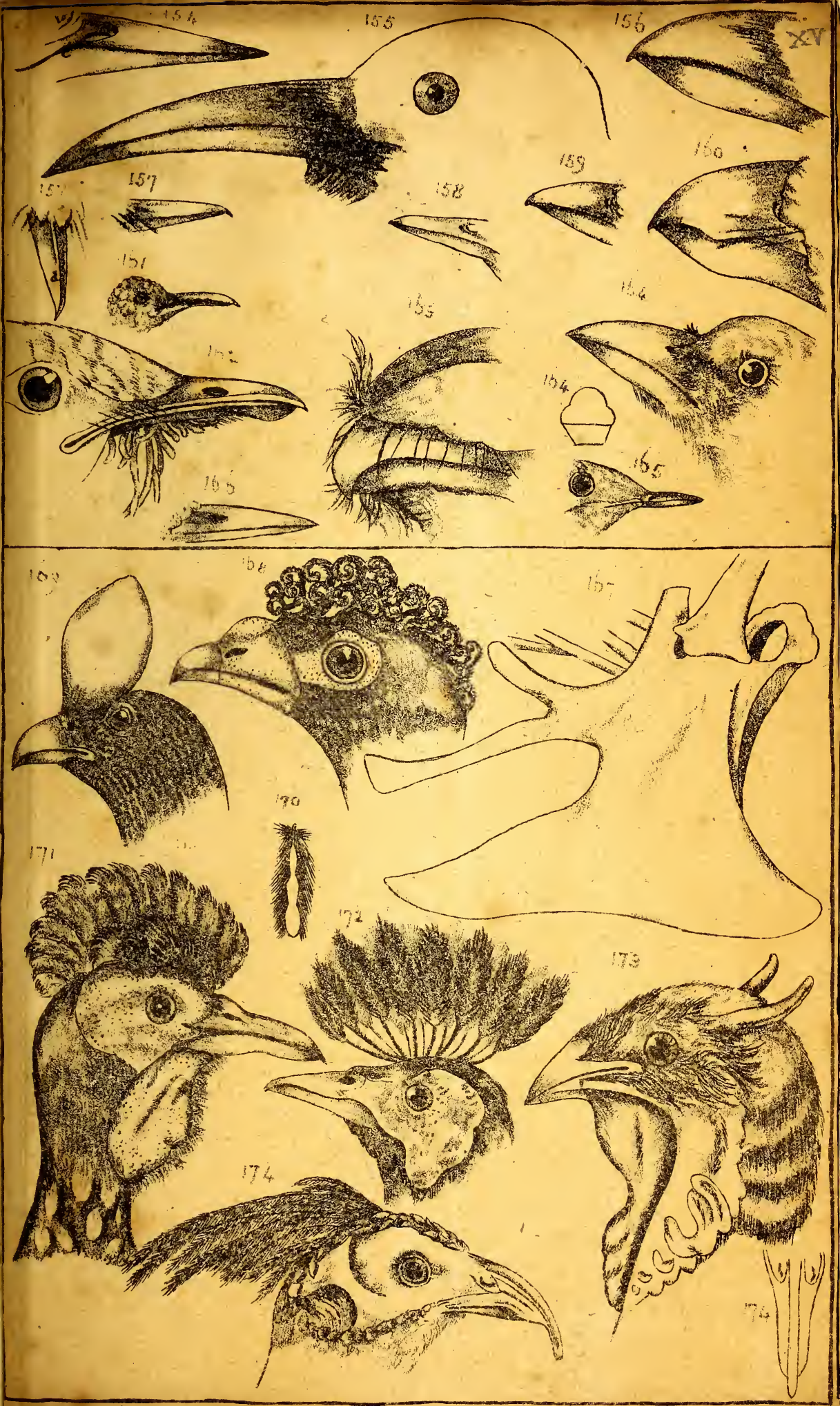

S Bowndoh Lithos: 



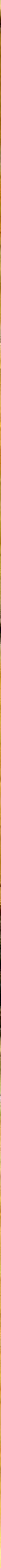





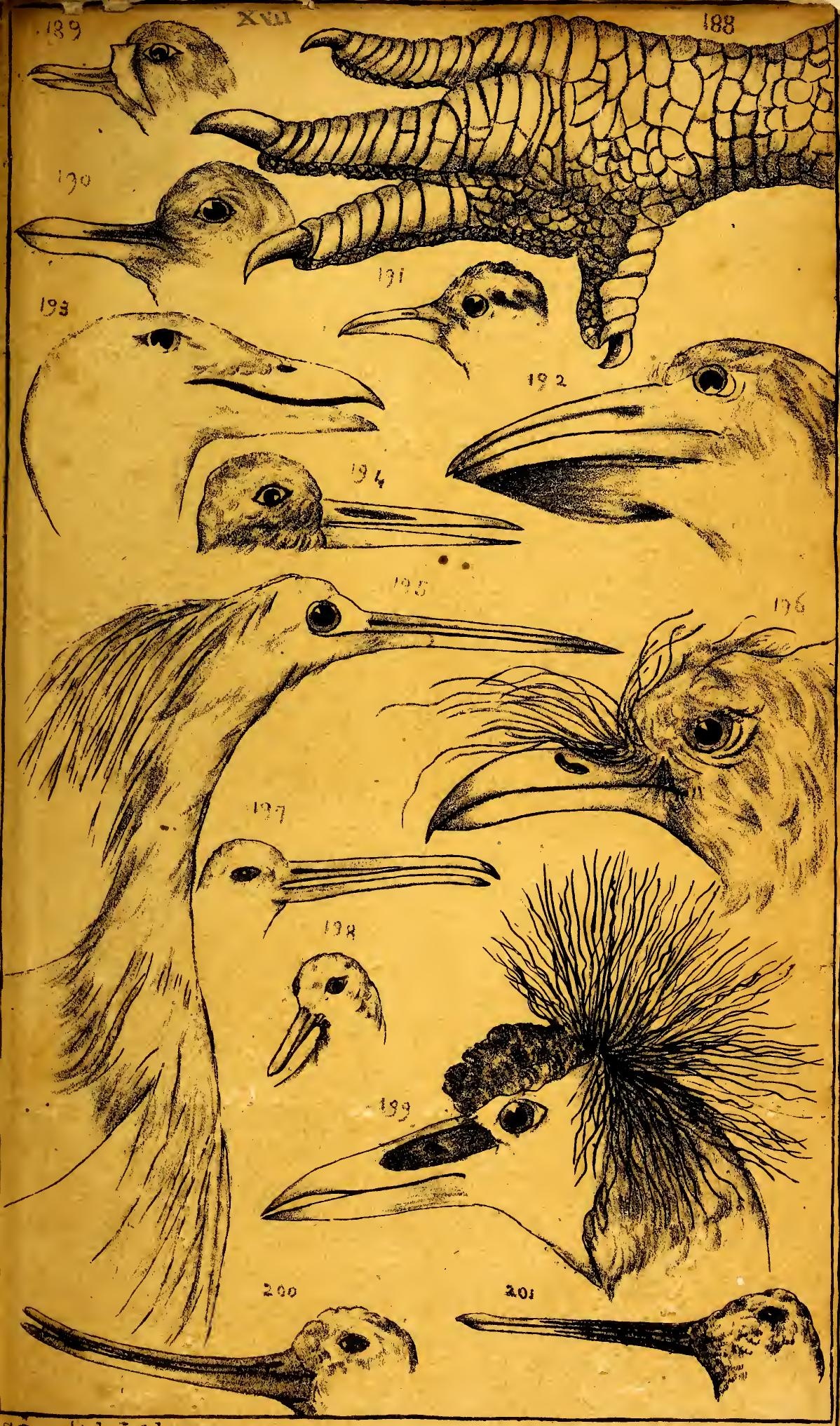

SBowdich. Lithog: 


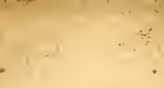

है

$+1$

.

I

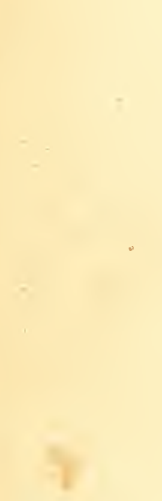




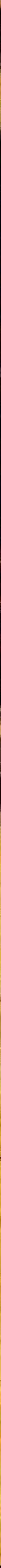

SBowdich́. Lithat: 



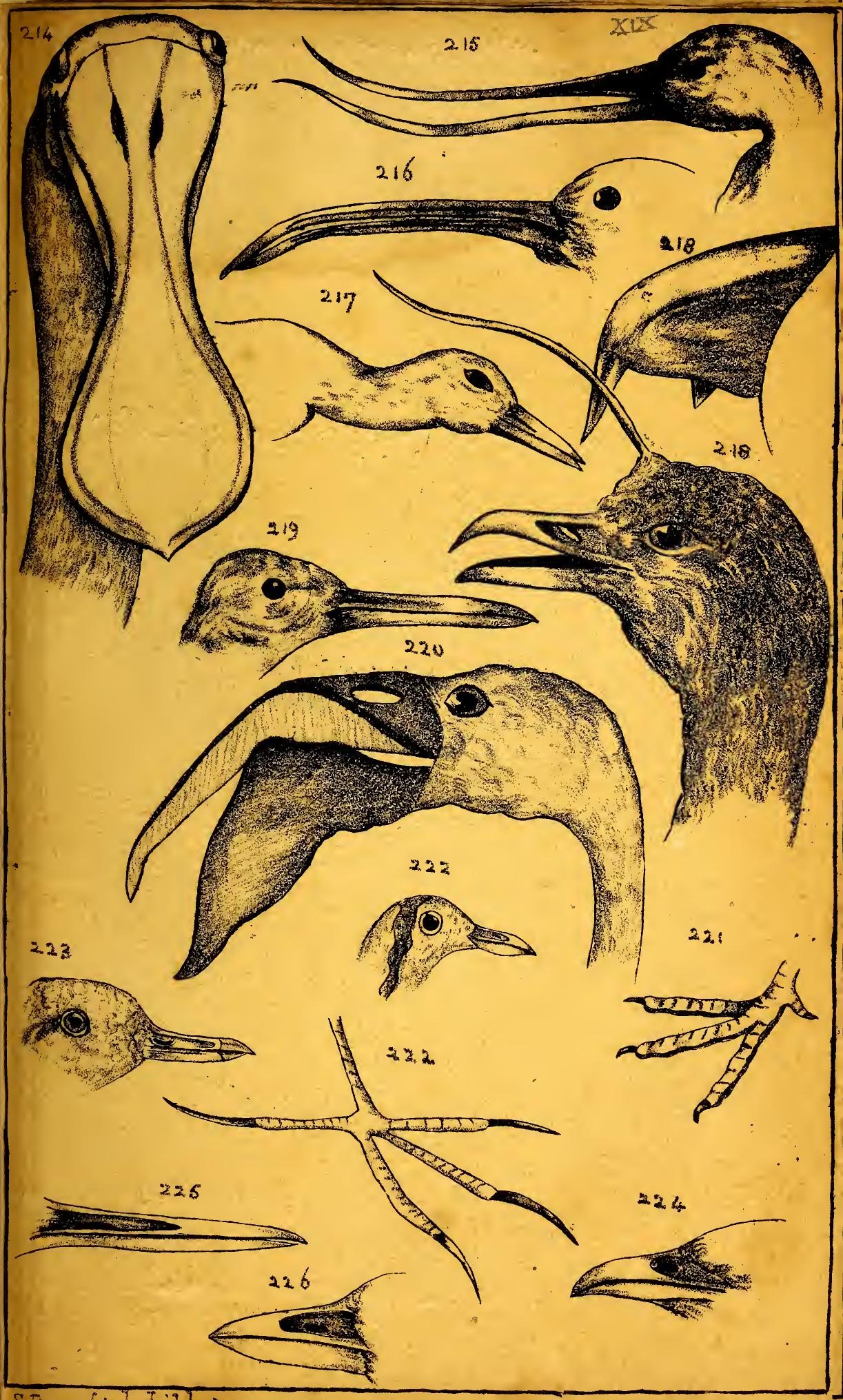

SEowdich. Lithos: 




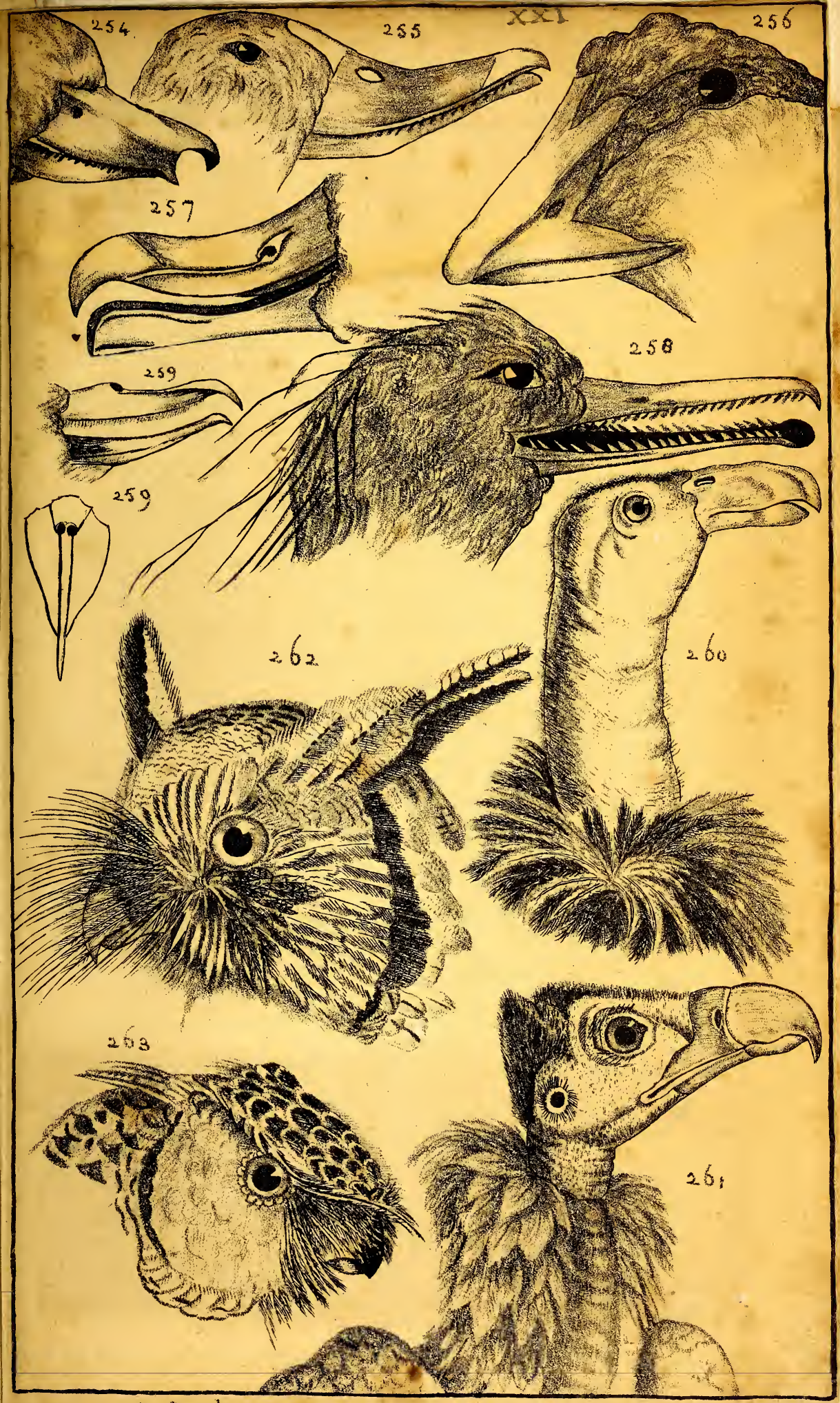

SBowdich Lithoy: 
(.) $=2+5$

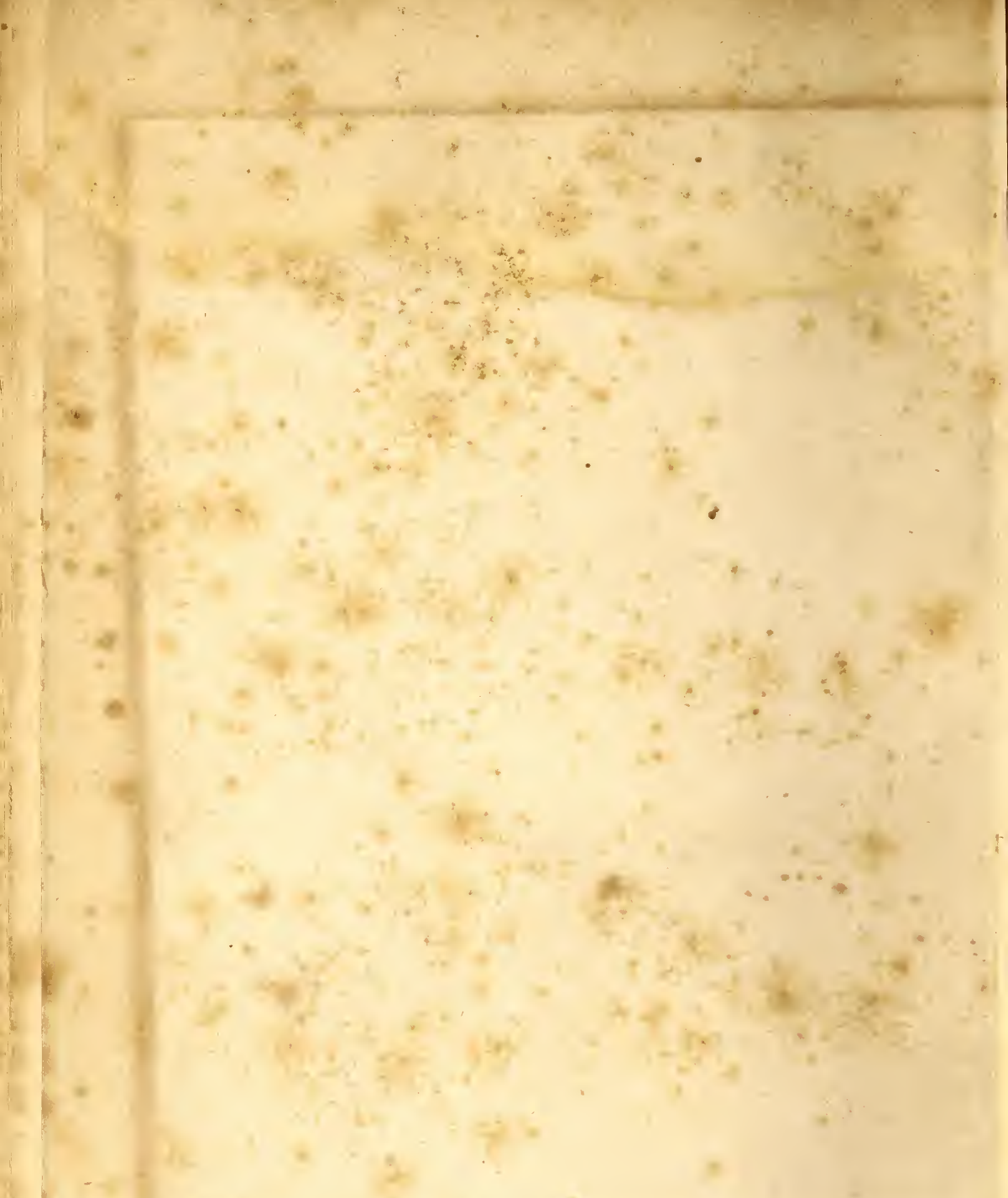


la conversion des alcalis minéraux combinés aux acides organiques, en carbonates alcalins. Depuis des observations intéressantes dues à II. Wochler, on considérait cette transformation comme un phếnomène constant ; elle est, au contraire, d'une extrême variabilité.: Sur : 68 ingestions, 175 ont été suivies d'urines alcalines, 87 d'urines acides et 6 d'urines sensiblement neutres. On peut, en suivant certaines règles, provoquer l'expulsion complète du sel de Seignetts par le tube intestinal ; le passage du sel par les urines est alors un cas infiniment rare. On peut, au contraire, le faire pénétrer dans l'économie, saturer ainsi les urines d'une dose énorme de carbonate alcalin; l'évacuation du tartrate par les selles devient l'exception.

Si un grand nombre de médicaments se trouvent soumis à de semblables variations, il est difficile de croire qu'il en soit autrement, on comprend quel prix doit attacher la médecine à éviter ces variations ou à les faire tourner à son profit.

A près avoir décrit avec soin les méthodes d'analyse qu'ils ont mises en usage, MV. Laveran et Millon établissent qu'il est constant que le sel de Seignette ne s'échappe jamais par les urines à l'état de tartrate, et que celui qui prend cette voie est entièrement converti en carbonate.

Lorsque le sel de Seignette est pris en peu de temps et à la dose de 40 à 50 grammes, son effet tend à se concentrer sur les voies digestives. Les vomissements sont très-rares, mais l'ingestion est toujours suivie de plusieurs selles liquides. Ce n'est que d'une manière exceptionnelle que les malades n'éprouvent rien du côté dọ tube digestif ; mais, dans ce dernier cas, ils rendent des urines alcalines.

Prescrit à petite dose, de manière que 20,30 ou 40 grammes ne soient pris qu'en huit ou dix heures, le tartrate double produit des effets opposés. Dans ce cas, la purgation est l'exception; l'alcalinité des urines devient J'état habituel : un seul litre d'urine peut saturer jusquà 250 divisions de l'acide sulfurique norınal, versé goutte à goutte, à l'aide de la burette alcalimét rique de M. GayLussac. De sorte qu'en ne tenant compte que du tartrate double de sonde et de potasse, on voit qu'à haute dose il est dirsctement expulsé par le imouvement de l'intestin ; tandis que de jetites quantités. bien qu'elles soient réitérées, pénètrent l'économie, sont transformées par elle, amenées au dernier terme d'oxydation 


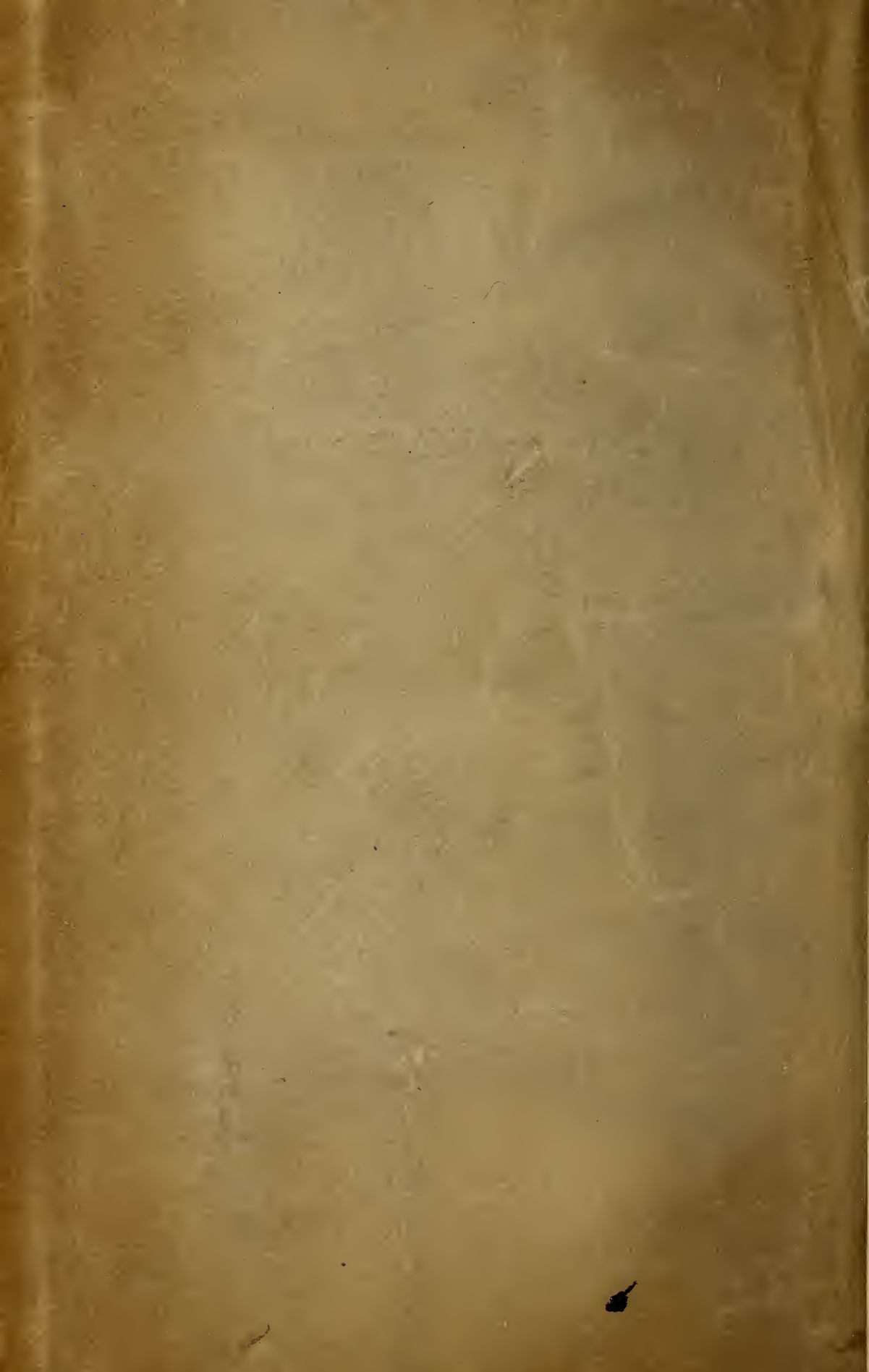







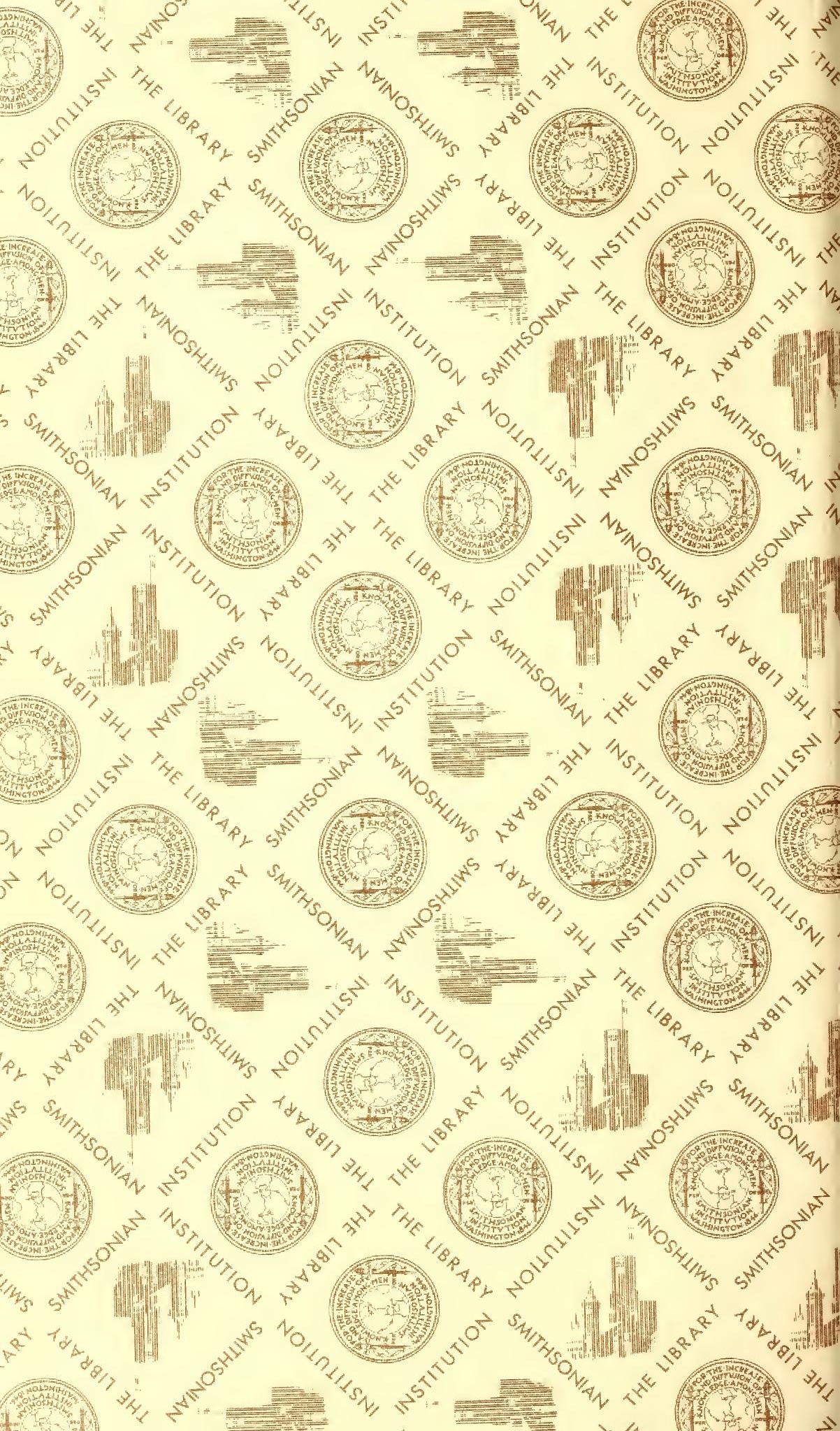


SMITHSONIAN INSTITUTION LIBRARIES 